\title{
Historical Assessment and Archeological Survey of 4.9 Miles of FM 2092 From Menard to Fivemile Crossing, Menard County, Texas
}

Jennifer K. McWilliams

Texas Historical Commission

Douglas K. Boyd

Prewitt and Associates, Inc.

Celine Finney

Prewitt and Associates, Inc.

Follow this and additional works at: https://scholarworks.sfasu.edu/ita

Part of the American Material Culture Commons, Archaeological Anthropology Commons, Environmental Studies Commons, Other American Studies Commons, Other Arts and Humanities Commons, Other History of Art, Architecture, and Archaeology Commons, and the United States History Commons

Tell us how this article helped you.

This Article is brought to you for free and open access by the Center for Regional Heritage Research at SFA ScholarWorks. It has been accepted for inclusion in Index of Texas Archaeology: Open Access Gray Literature from the Lone Star State by an authorized editor of SFA ScholarWorks. For more information, please contact cdsscholarworks@sfasu.edu. 
Historical Assessment and Archeological Survey of 4.9 Miles of FM 2092 From Menard to Fivemile Crossing, Menard County, Texas

\section{Creative Commons License}

\section{c) (1)@ $\Theta$}

This work is licensed under a Creative Commons Attribution-NonCommercial-No Derivative Works 4.0 International License. 


\title{
HISTORICAL ASSESSMENT AND ARCHEOLOGICAL SURVEY OF 4.9 MILES OF FM 2092 FROM MENARD TO FIVEMILE CROSSING, MENARD COUNTY, TEXAS
}

\author{
by \\ Jennifer K. McWilliams \\ Douglas K. Boyd \\ and \\ Céline Finney \\ with contributions by \\ Karl W. Kibler \\ Principal Investigator: Douglas K. Boyd \\ REPORTS OF INVESTIGATIONS, NUMBER 155 \\ Prewitt and Associates, Inc. \\ Cultural Resources Services \\ Austin, Texas
}

ARCHEOLOGICAL STUDIES PROGRAM, REPORT NO. 103

Texas Department of Transportation

Environmental Affairs Division

Archeological Studies Program

November 2007

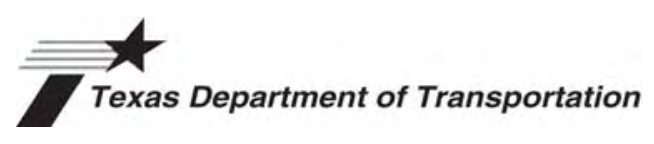

TEXAS ANTIQUITIES PERMIT NO. 4192 


\section{HISTORICAL ASSESSMENT AND ARCHEOLOGICAL SURVEY \\ OF 4.9 MILES OF FM 2092 FROM MENARD TO FIVEMILE CROSSING, MENARD COUNTY, TEXAS}

COPYRIGHT @ 2007

Texas Department of Transportation (TxDOT) and Prewitt and Associates, Inc. (PAI)

TxDOT and PAI jointly own all rights, title, and interest in and to all data and other information developed for this project under Contract 575XXSA006, Work Authorization 57540SA006. Brief passages from this publication may be reproduced without permission provided that credit is given to TxDOT and PAI. Permission to reprint an entire chapter, section, figures or tables must be obtained in advance from the Supervisor of the Archeological Studies

Program, Environmental Affairs Division, Texas Department of Transportation, 125 East 11th Street, Austin, Texas, 78701.

jointly published by the

Texas Department of Transportation

Environmental Affairs Division

Archeological Studies Program

Scott Pletka, Ph.D., Supervisor, Archeological Studies Program

Archeological Studies Program, Report No. 103

Al McGraw, Series Editor

and

Prewitt and Associates, Inc.

Cultural Resources Services

Austin, Texas

PAI Project Nos. 206025 and 207047

Reports of Investigations, Number 155

Printed by Morgan Printing in Austin, Texas

ISBN 1-930788-72-X 


\section{TABLE OF CONTENTS}

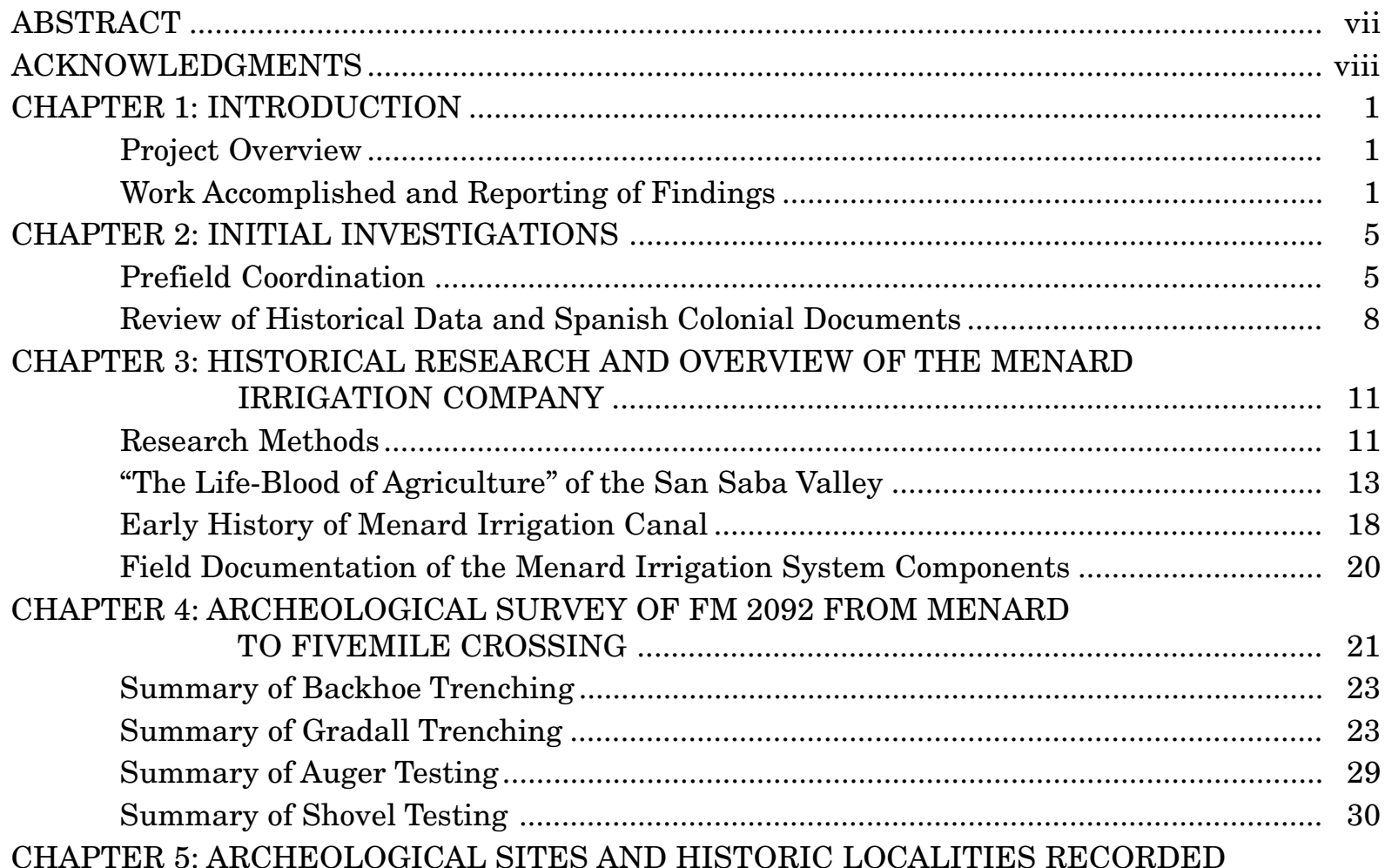

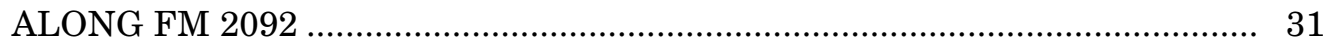

Previously Recorded Sites in the FM 2092 Right of Way .......................................... 31

41MN5, Sunnyside Community ................................................................... 31

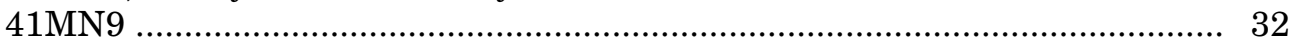

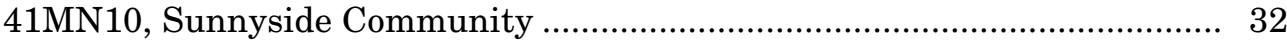

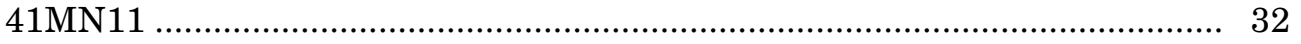

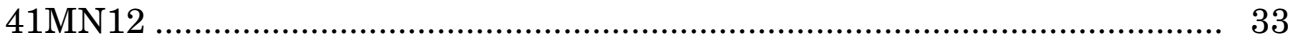

41MN13, Doug Matthews Grocery Store ................................................. 33

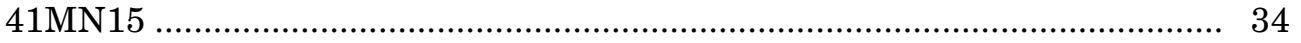

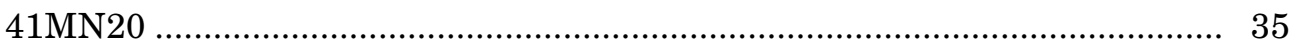

41MN21, Menard Irrigation Company System ........................................ 35

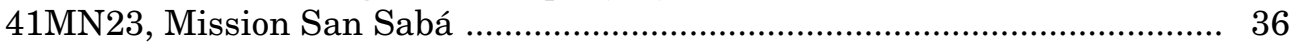

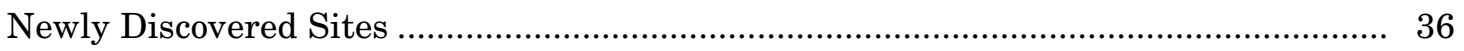

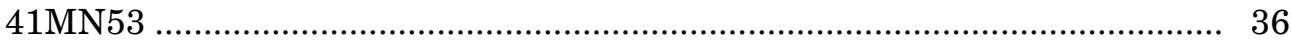

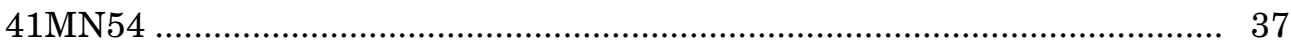

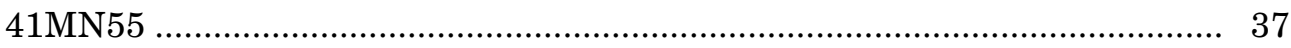

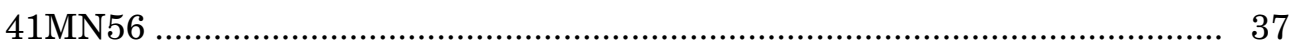

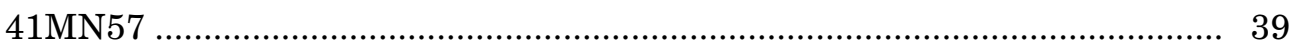

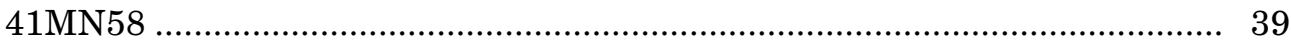

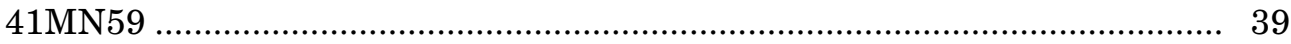

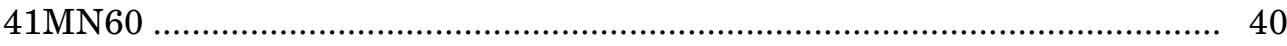

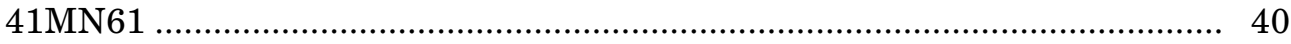

Historic Localities Identified in Archival Records or by Informants ........................... 41

Ditch Crossings 1-5 ................................................................................. 41

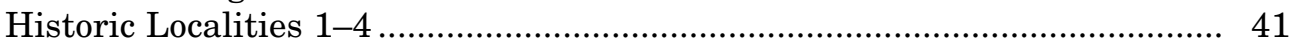

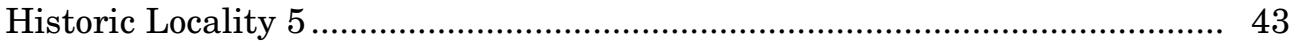




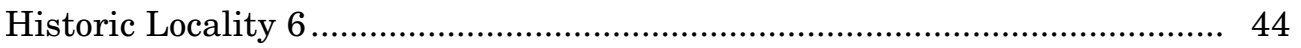

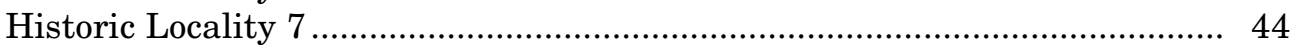

Historic Localities 8-10 ............................................................................ 44

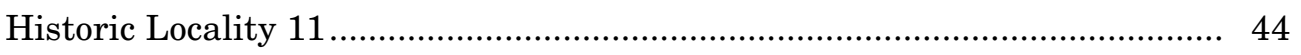

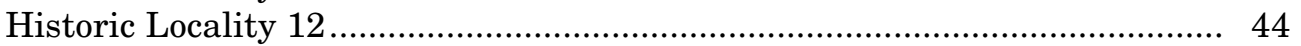

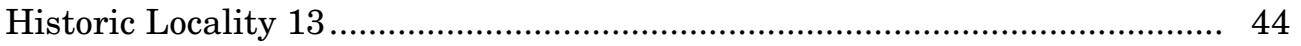

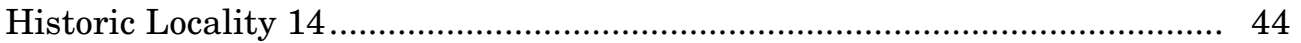

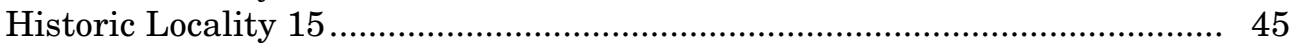

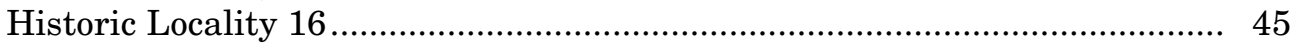

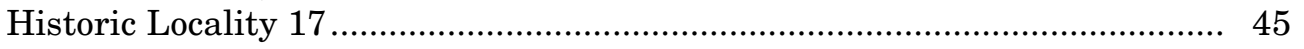

CHAPTER 6: NATIONAL REGISTER ASSESSMENTS, EVALUATION

OF PROJECT-RELATED IMPACTS, AND MANAGEMENT

RECOMMENDATIONS .................................................................... 47

Preliminary Survey Report and Project Review by TxDOT and THC ........................ 47

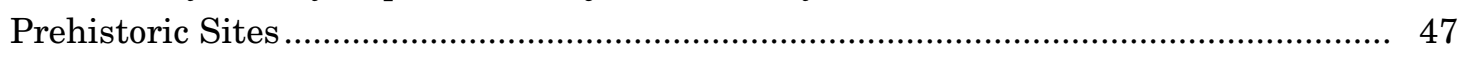

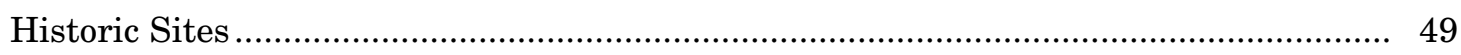

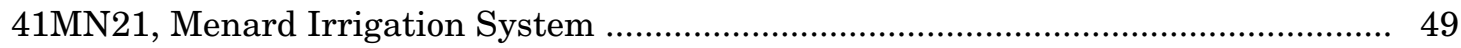

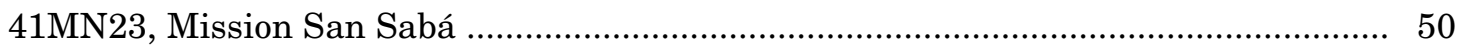

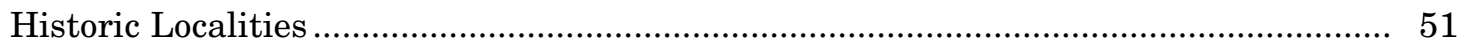

Public Outreach Brochure ..................................................................................... 51

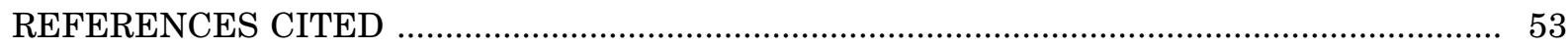

APPENDIX A: Tabulated Historical Data for the San Saba River Valley

Near Menard, Texas .............................................................................. 57

APPENDIX B: Geological Profile Descriptions of Selected Backhoe Trenches ......................... 87

APPENDIX C: Summary of Excavation Results at Archeological Sites

in the FM 2092 Survey Area ....................................................................... 95 


\section{LIST OF FIGURES}

1. Project area map

2. Map of previously recorded archeological sites in the San Saba River valley near Menard

3. Map of the FM 2092 project area showing the six locations identified as areas needing mechanical trenching

4. Map of "Vaughan's Agricultural and Mechanical Canal" from 1875

5. Comparison of the 1875 map of Vaughan's Agricultural and Mechanical Canal with modern topography in the vicinity of Menard, Texas

6. J. J. Callan map showing the present and previous irrigation canals near Menardville in 1901

7. Project map showing locations and excavations at 19 recorded archeological sites along FM 2092

8. Plan and profile of 41MN55, a probable Toyah phase occupation site on a Pleistocene terrace overlooking the San Saba River floodplain at Fivemile Crossing ......

9. Project area map showing locations of historic localities and ditch crossings along FM 2092 


\section{LIST OF TABLES}

1. Summary of previously recorded sites in the vicinity of the FM 2092 project area .............. 7

2. Historical timeline for the Menard Irrigation Canal ........................................................... 12

3. Summary of excavations for the FM 2092 project area .................................................... 21

4. Summary of mechanical and hand excavations in the FM 2092 project area

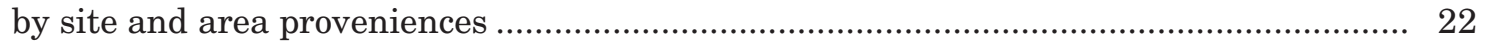

5. Summary of all sites recorded in and near the FM 2092 project area ................................ 24

6. Assessments and recommendations for portions of archeological sites within the FM 2092 right of way .................................................................................. 48

A.1. Observations on historical resources and features along FM 2092 between

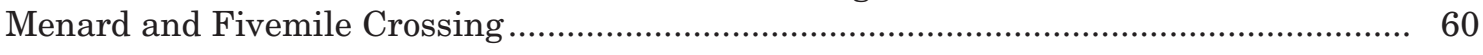

C.1. Summary of excavation results at and near archeological sites ................................. 97 


\begin{abstract}
This preliminary report describes historical research and an intensive archeological survey conducted for a 4.9-mile-long stretch of FM 2092 in Menard County by Prewitt and Associates, Inc. The work was performed for the Texas Department of Transportation in conjunction with a road improvement project beginning at the eastern Menard city limit and extending eastward to just beyond Fivemile Crossing. Crossing over Pleistocene and Holocene alluvial terraces of the San Saba River, the project area is located in a high-probability area for buried prehistoric sites and has a dynamic history of intensive use since Spanish colonial times. Investigations included geoarcheological mapping, historic research and evaluation, pedestrian survey, backhoe and gradall trenching, mechanical auger testing, and shovel testing.
\end{abstract}

Archeological remains of 10 previously recorded sites and 9 newly discovered sites were documented within the FM 2092 right of way. Of these 19 sites, 6 have prehistoric components, 4 have historic components, and 9 have both prehistoric and historic components. At 14 of the 15 sites with prehistoric components, either no prehistoric remains were found within the right of way or the prehistoric remains are very low density and extensively disturbed. No prehistoric features were encountered at any of these 14 sites. The prehistoric components at these 14 sites (41MN5, $41 \mathrm{MN} 9,41 \mathrm{MN} 11,41 \mathrm{MN} 12,41 \mathrm{MN} 15,41 \mathrm{MN} 23,41 \mathrm{MN} 53,41 \mathrm{MN} 54$, and 41MN56-61) were recommended as not eligible for listing in the National Register, while the portion of 41MN55 inside the right of way was recommended as eligible. Site $41 \mathrm{MN} 55$ was subsequently tested, and the results of this work are reported separately.

At 11 of the 13 sites with historic components, either no historic remains were found within the right of way or historic remains were limited to nondiagnostic artifacts (i.e., that could date to the late nineteenth or early twentieth centuries) in disturbed contexts. Although intact deposits and historic features associated with these sites may be present outside the right of way, none were observed in the right of way. It was recommended that these 11 sites (41MN5, 41MN9, 41MN10, $41 \mathrm{MN} 12,41 \mathrm{MN} 13,41 \mathrm{MN} 15,41 \mathrm{MN} 20,41 \mathrm{MN} 53,41 \mathrm{MN} 54,41 \mathrm{MN} 60$, and 41MN61) are not eligible for listing in the National Register.

During this survey, hand and mechanical excavations were conducted at 41MN23, the site of the historic Mission San Sabá. The portion of the site within the FM 2092 right of way was recommended as eligible for listing in the National Register. Intensive data recovery excavations were subsequently conducted, but these investigations are reported separately.

Site 41MN21 is the Menard Irrigation Company canal and associated smaller lateral ditches that comprise the entire irrigation system. Historical research documents that construction of this canal system started in 1874 and expanded in the late 1800s. The system is still used for agricultural irrigation today. Portions of the irrigation system crossing the FM 2092 right of way were documented. The system is probably eligible for listing in the National Register, but the irrigation system will not be impacted by this road project, and no further work is recommended.

\title{
CURATION
}

All project records generated by this survey project will be submitted for permanent curation at the Texas Archeological Research Laboratory at The University of Texas at Austin. For this project, PAI employed a general no-collection policy. Selected diagnostic artifacts were collected from 41MN55, but they will be curated with materials from a subsequent testing project. 


\section{ACKNOWLEDGMENTS}

A multidisciplinary approach was used to research and survey this particularly historic 5mile section of Texas roadway. Researchers, state workers, local informants as well as archeologists were brought together to offer information regarding the rich history of this area.

The cultural resources studies conducted by PAI were directly supervised by the Archeological Studies Program, Cultural Resources Management Section at the Environmental Affairs Division, Texas Department of Transportation (TxDOT-ENV). John Arnn served as project manager and Jim Abbott assisted with geomorphology concerns. Personnel from the TxDOT San Angelo District Office included Nancy Fisher and Ann Maxwell of the ENV Department and Public Information Officer Karen Threlkeld. Emiliano Gonzales of the Menard Maintenance Office scheduled auger, backhoe, and gradall services and handled safety coordination. Guy Wagoner was especially helpful with fulfilling any of our TxDOT needs while we were in the field.

Consultants Kay Hindes (historian), Mark Wolf (historian), Dr. Grant Hall (archeologist, Texas Tech University), and Dr. William Doolittle (geographer and irrigation system specialist, University of Texas at Austin) shared their research, expertise, and time. Dr. Jake Landers, a local landowner and TAMU extension range specialist, conducted research on graves located along the FM 2092 corridor and offered his knowledge of the estimated ages of trees along FM 2092. Alicia Brown, who maintains the Menard County TexGenWeb Project web page, was also helpful in providing information about the graves. Dora Wright, also a local genealogy researcher, offered access to publications from her personal library about historic Menard. Jerry Rambo provided extensive information on the history of FM 2092 during an interview conducted by Kay Hindes and Jennifer McWilliams. Finally, Susan Smith Dorsey of the Texas General Land Office made recently scanned historical maps available to us for the FM 2092 historical research.

Field crew consisted of Bennett Kimbell, Jenni Hatchett, and Cory Broehm. Doug Boyd of Prewitt and Associates, Inc., served as the principal investigator, and Jennifer McWilliams was the project archeologist. Karl Kibler served as the geomorphologist. Historian Céline Finney conducted some of the research pertaining to the Menard Irrigation Company. Elaine Robbins edited this report, and Sandra Hannum and Brian Wootan produced the figures. 


\title{
INTRODUCTION
}

\author{
Douglas K. Boyd
}

\section{PROJECT OVERVIEW}

This report reviews historical and archeological investigations conducted for the Texas Department of Transportation (TxDOT) in conjunction with road improvements to FM 2092 in Menard County, Texas. The road project is being undertaken by the San Angelo District (CSJ No. 2008-01-091) and involves a 4.9-mile segment of FM 2092 located east of the town of Menard (Figure 1). TxDOT plans to restore, resurface, and widen the 4.9-mile-long segment of FM 2092, beginning 0.4 miles east of U.S. 83 in Menard and extending eastward just past Fivemile Crossing of the San Saba River. The proposed transportation enhancement project will include widening the two travel lanes and adding shoulders. The proposed restoration will consist of grinding up the existing pavement and leaving it in place as the subbase and adding new pavement as necessary to achieve the appropriate width and depth. However, projectrelated construction impacts may occur anywhere within TxDOT's 100-ft-wide road right of way. Excluding the 40-ft-wide existing paved road, the archeological survey area for this project is $16 \mathrm{ft}$ wide on both the north and south sides of the road, for a total right of way width of $72 \mathrm{ft}(22 \mathrm{~m})$. The increase in pavement will total $8 \mathrm{ft}(2.4 \mathrm{~m})$, for a total road-expansion area of 4.75 acres. Project-related impacts will be extensive within this area because several feet of fill will be removed and replaced. Additional project-related impacts will occur throughout the right of way as heavy machinery is used for construction and reshaping of the borrow ditches. The Area of Potential Effect (APE) for this project is considered to be the entire right of way.
Although the FM 2092 transportation enhancement project is being undertaken by TxDOT's San Angelo District, the cultural resources studies conducted by Prewitt and Associates, Inc. (PAI), are directly supervised by the Archeological Studies Program, Cultural Resources Management Section of TxDOT's Environmental Affairs Division (TxDOT-ENV). Because the road project involves no new right of way, all of the field investigations were conducted within the road right of way on property owned by the State of Texas.

All of the work described in this report was done in compliance with federal and state cultural resources laws, specifically Section 106 of the National Historic Preservation Act (16 USC 470 et seq.; 36 CFR 800) and the Antiquities Code of Texas (Texas Natural Resources Code, Title 9, Chapter 191; 13 TAC 26). Because the work was done on property owned by the State of Texas, the cultural resources studies were done under the authority of Texas Antiquities Permit No. 4192 issued by the Texas Historical Commission (THC). All of the cultural resources described in this report are evaluated relative to the criteria for listing on the National Register of Historic Places under the National Historic Preservation Act and for designation as a State Archeological Landmark under the Antiquities Code of Texas.

\section{WORK ACCOMPLISHED AND REPORTING OF FINDINGS}

The work reported in this volume was conducted under two separate work authorizations issued to PAI relating to the FM 2092 road improvement project. Testing of two sites along FM 2092-41MN23 and 41MN55-is reported 


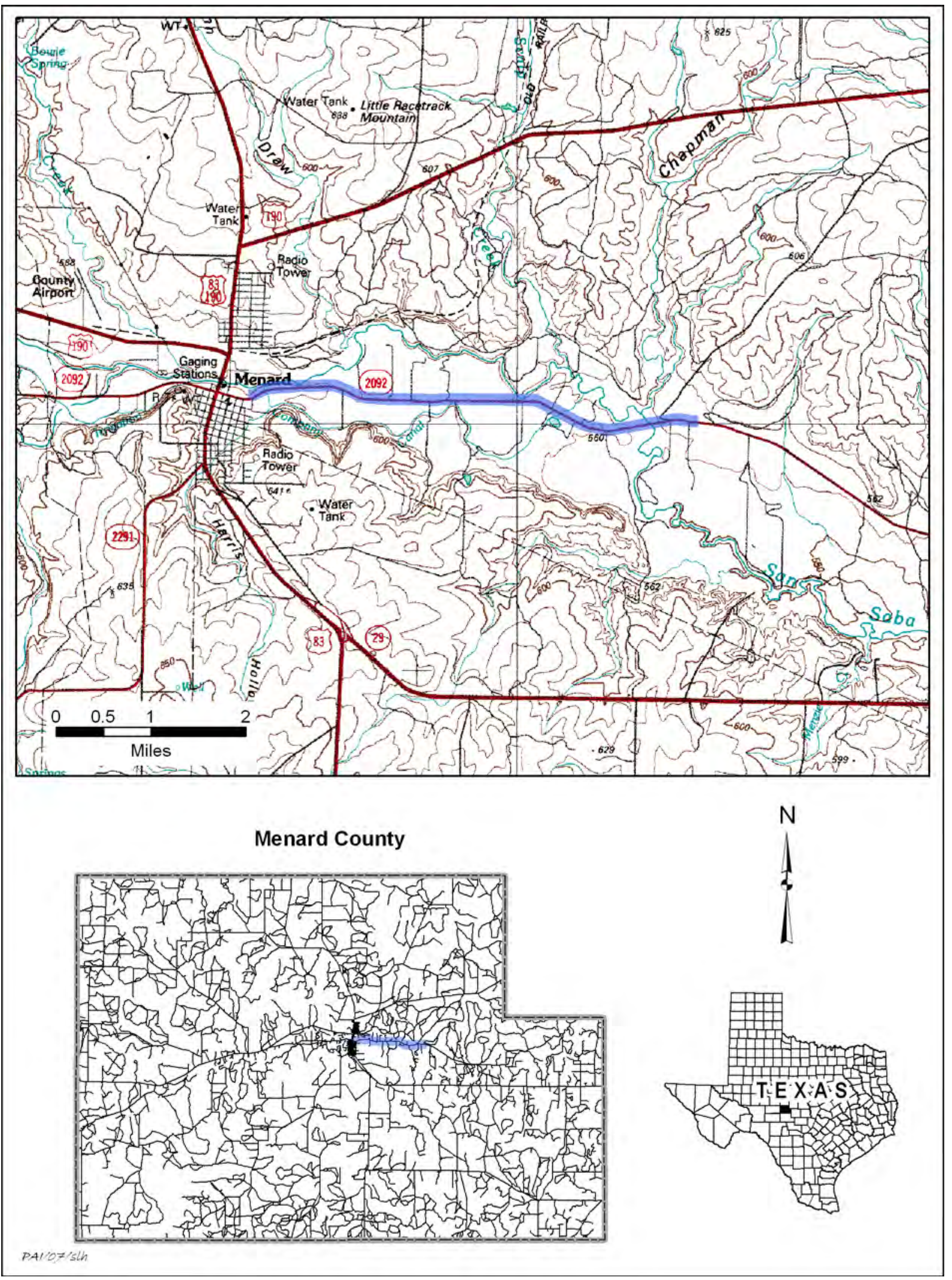

Figure 1. Project area map. 
in a later publication. PAI was issued the first work authorization (WA No. 57536SA006, March 31,2006) to develop a scope of work and outline the methodology for an intensive survey of the FM 2092 project area. This was completed and approved in May 2006. A second work authorization (WA No. 57540SA006, May 17, 2006) was then issued to conduct an intensive geoarcheological survey along the 4.9-mile-long project area and conduct historical research on certain historical sites. For this work, a final scope of work was submitted to the Texas Historical Commission (THC) as part of the antiquities permit application to conduct the archeological investigations. THC issued Texas Antiquities Permit No. 4192 on July 7, 2006, to authorize an intensive survey with mechanical trenching of the FM 2092 project area. The historical research was completed, the archeological survey was conducted from July 10 to 28, 2006, and a preliminary report of findings was prepared in September 2006 (Boyd et al. 2006).

Following this work, TxDOT issued the third work authorization (WA No. 57548SA006) to conduct testing of one prehistoric site, 41MN55, and data recovery excavations at Mission San Sabá (41MN23). THC issued Texas Antiquities Permit No. 4317 on November 13, 2006, to authorize the site testing and data recovery. The testing of 41MN55 took place from November 13 to 17,2006 , and the data recovery work at the mission was conducted between November 27, 2006, and February 9, 2007.

Several different tasks were completed under these work authorizations, but not all of the work is reported here. This volume reports on the following tasks:

- Review of previously recorded prehistoric and historic archeological sites in or near the FM 2092 corridor.

- Historical research on the Menard Irrigation Company Canal, 41MN21.

- Intensive historical documentation research regarding known or possible historic localities in or near FM 2092.

- Geoarcheological assessment of the project area.

- Intensive archeological survey of FM 2092 (excluding the mission area).

- National Register assessments of newly recorded and previously recorded and revisited sites, evaluation of project impacts, and management recommendations.

The following tasks were also completed as part of the FM 2092 project, but are reported separately:

- Transcription and translation of selected Spanish documents, by Mariah Wade (2007).

- Review of previously published historical data, unpublished research notes compiled by historians Kay Hindes and Mark Wolf, and other mission-related documents (McWilliams et al. 2007).

- Intensive archeological survey and data recovery excavations at Mission San Sabá, $41 \mathrm{MN} 23$, including the 0.2 -mile-long "Mission Search Area" (McWilliams et al. 2007).

- Archeological testing and National Register assessment of a Toyah phase occupation at 41MN55 (McWilliams et al. 2007).

From a methodological standpoint, the 4.9mile-long project area was divided into two areas with different types of cultural resources. A 0.2 -mile-long $(350 \mathrm{~m})$ stretch of the roadway in the vicinity of Mission San Sabá (41MN23) was defined as the "Mission Search Area." The remaining 4.7 miles $(7.6 \mathrm{~km})$ of the roadway, including ca. 1.8 miles east and ca. 2.9 miles west of the Mission Search Area, was identified as the FM 2092 survey area. Because of the nature of the known and possible cultural resources in these locations, different field methods were employed to investigate these areas.

The field investigations of the FM 2092 project area included a pedestrian survey of the 4.9-mile-long stretch of FM 2092, along with excavation of 13 backhoe trenches, 1 gradall trench, and 32 shovel tests inside the TxDOT right of way. The work resulted in recording of 9 new sites and revisits to 10 previously recorded sites. These are classified as 6 prehistoric sites, 4 historic sites, and 9 sites with both prehistoric and historic components. The latter group includes the prehistoric and Spanish colonial deposits at Mission San Sabá. 
TxDOT and PAI held a postfield meeting on August 15, 2006, to expedite the cultural resources review process under federal and state laws. All of the survey results were reviewed at that meeting, and it was agreed that additional archeological work at the mission site and one prehistoric site (41MN55) would be appropriate. Because of the construction schedule proposed by the San Angelo District and the need to expedite the federal and state review processes, it was decided that PAI should prepare and submit a preliminary report on the FM 2092 survey project. The analysis of cultural materials and presentation of all data, as required in a full report on the investigations, would be delayed so that a preliminary report could be quickly prepared. The majority of this document is taken from that preliminary report (Boyd et al. 2006).

The remainder of this report summarizes the work that was done for the FM 2092 survey project, describes the cultural resources that were found, and presents assessments of $\mathrm{Na}$ tional Register and State Archeological Landmark eligibility for the resources within the FM 2092 right of way. This report documents only the archeological survey of the 4.7-mile FM 2092 project area, excluding the mission area. Subsequent work was conducted at 41MN55 (testing of prehistoric remains) and at 41MN23 (data recovery at Mission San Sabá), but these investigations will be reported separately (interim reports are Boyd and Mehalchick [2007] and McWilliams et al. [2007]). 


\title{
INITIAL INVESTIGATIONS
}

\author{
Jennifer K. McWilliams
}

2

\section{PREFIELD COORDINATION}

A variety of prefield tasks were undertaken. One of the first tasks was to conduct archeological background research using the online Texas Archeological Sites Atlas and the site files at the Texas Archeological Research Laboratory (TARL) in Austin. This research revealed that 22 prehistoric and historic archeological sites were documented in the San Saba River valley between the presidio and Fivemile Crossing, east of Menard (Figure 2; Table 1). Of these, 19 are located east of Menard in close proximity to the FM 2092 project area. In Figure 2, it is notable that the TARL site plottings show most of the sites as dots, and precise site boundaries are not depicted. Other sources for site boundaries have minor discrepancies (discussed below). The sources include site plottings in individual site files at TARL and site plottings on a 1990 survey map (provided courtesy of Shawn Carlson, Star of the Republic Museum, and Patricia Clabaugh, Anthropology Department, Texas A\&M University).

Modern and historic aerial photographs were carefully examinedhs along with Schlenker's (1991) previous geomorphological study of the San Saba River valley, done in conjunction with Carlson's (1991) Texas A\&M University survey. Carlson's study provided baseline geomorphology interpretations for the San Saba River near Menard.

Historic aerial photographs of the project area were ordered from the Texas Natural Resources Information System. The earliest available photographs for the area date to June 2, 1954, just one year before FM 2092 was straightened and paved. TxDOT provided the 1954 engineering schematic for the FM 2092 road improvements. These plans, which were finalized on May 6, 1955, helped us re-locate irrigation laterals and historic building locations adjacent to the roadway. Historic maps were also consulted to try to pinpoint the route of the historic roadway and to chart historically mapped riverbed channels. Historic maps were collected and/or copied from Mark Wolf's research files, the Texas General Land Office, and the Texas State Library and Archives (both library and Internet website files).

Two onsite meetings were held before the archeological survey began. These meetings, between PAI and TxDOT personnel and various consultants, had two primary goals. The first meeting was held to discuss historical resources and logistics for the fieldwork. The other focused on the geomorphology of the project area.

An onsite project review meeting was held on June 7, 2006, to finalize the strategy for investigating the Spanish colonial remains and to make logistical arrangements for the fieldwork. Participants in this meeting were PAI personnel (Boyd and McWilliams), personnel from the TxDOT San Angelo District Office (Nancy Fisher and Ann Maxwell, Environmental Affairs Division (TxDOT-ENV), and Karen Threlkeld, Public Information Officer) and the TxDOT Menard Maintenance Office (Emiliano Gonzales), and consultants Kay Hindes (historian), Mark Wolf (historian), Dr. Grant Hall (archeologist, Texas Tech University), and Dr. William Doolittle (geographer and irrigation system specialist, The University of Texas at Austin).

The primary purpose of the meeting was to discuss the potential for Spanish colonial, nineteenth-century archeological remains along FM 2092 and to get input on the project area from these knowledgeable researchers. During this 


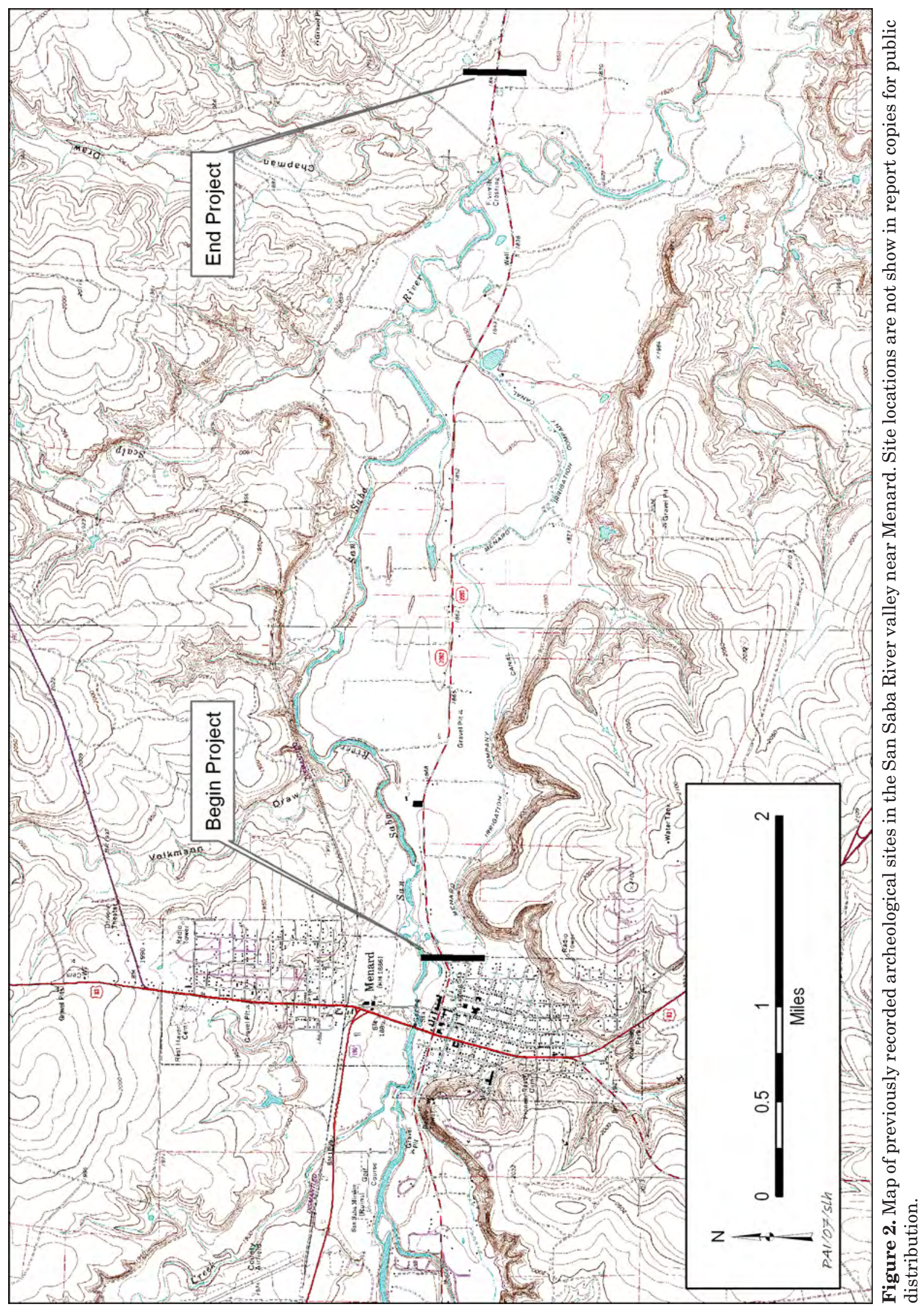


Table 1. Summary of previously recorded sites in the vicinity of the FM 2092 project area*

\begin{tabular}{|c|c|c|}
\hline Site Number & Site Type & Description \\
\hline $41 \mathrm{MN} 1 * *$ & Historic (Spanish colonial) & Spanish presidio, San Luis de las Amarillas \\
\hline $41 \mathrm{MN5}$ & Historic and prehistoric & $\begin{array}{l}\text { Cotton gin; prehistoric campsite (Early Archaic, Late } \\
\text { Prehistoric) }\end{array}$ \\
\hline $41 \mathrm{MN} 6$ & Prehistoric & Burned rock scatter with lithics \\
\hline $41 \mathrm{MN} 7$ & Prehistoric & Prehistoric campsite/light lithic scatter \\
\hline $41 \mathrm{MN} 8$ & Prehistoric & Prehistoric burned rock scatter with lithics \\
\hline $41 \mathrm{MN} 9$ & Historic and prehistoric & Historic farmstead (1880s to present); prehistoric campsite \\
\hline $41 \mathrm{MN} 10$ & Historic & $\begin{array}{l}\text { Historic farmstead (late nineteenth/early twentieth } \\
\text { century) }\end{array}$ \\
\hline $41 \mathrm{MN} 11$ & Prehistoric & Prehistoric campsite \\
\hline $41 \mathrm{MN} 12$ & Historic and prehistoric & $\begin{array}{l}\text { Historic (1930s) farmstead (Contact period artifacts?); } \\
\text { prehistoric campsite }\end{array}$ \\
\hline $41 \mathrm{MN} 13$ & Historic & $\begin{array}{l}\text { Historic farmstead (early twentieth century) and grocery } \\
\text { store }\end{array}$ \\
\hline $41 \mathrm{MN} 14$ & Historic and prehistoric & Historic dump; prehistoric burned rock scatter with lithics \\
\hline $41 \mathrm{MN} 15$ & Historic and prehistoric & Historic dump; prehistoric burned rock scatter with lithics \\
\hline $41 \mathrm{MN} 16$ & Historic and prehistoric & Historic dump; Prehistoric rock mound \\
\hline $41 \mathrm{MN} 17$ & Prehistoric & Prehistoric campsite \\
\hline $41 \mathrm{MN} 18$ & Historic and prehistoric & Historic dump; prehistoric burned rock scatter \\
\hline $41 \mathrm{MN} 19$ & Prehistoric & Prehistoric burned rock scatter with lithics \\
\hline $41 \mathrm{MN} 20$ & Historic & Historic farmstead (turn of the century) \\
\hline $41 \mathrm{MN} 21$ & $\begin{array}{l}\text { Historic (may include } \\
\text { Spanish colonial) }\end{array}$ & $\begin{array}{l}\text { Historic irrigation canal ( } 1874 \text { to present); portions of this } \\
\text { canal were probably built on the eighteenth-century } \\
\text { Spanish acequia }\end{array}$ \\
\hline $41 \mathrm{MN} 22$ & Historic and prehistoric & Historic farmstead \\
\hline $41 \mathrm{MN} 23$ & $\begin{array}{l}\text { Historic (Spanish colonial) } \\
\text { and Prehistoric }\end{array}$ & Spanish mission, Santa Cruz de San Sabá \\
\hline $41 \mathrm{MN} 24 * *$ & Historic (Spanish colonial) & Spanish dam at Presidio San Luis de las Amarillas \\
\hline $41 \mathrm{MN} 25^{* *}$ & Historic (Spanish colonial) & Spanish acequia \\
\hline
\end{tabular}

* Site plottings on the USGS 7.5-minute Menard and Chapman Draw quadrangles on file at the Texas Archeological Research Laboratory are dot symbols and true site boundaries are not shown. Thus, these maps do not indicate which of these site boundaries extends (as originally recorded) into the FM 2092 right of way.

**Site is located west of Menard. All others are located east of Menard within 0.5 mile of FM 2092.

meeting, all parties agreed to details regarding scheduling of fieldwork, safety coordination for trenching and surveying along the roadway, and availability of mechanical trenching equipment from the district (auger, backhoe, and gradall). At that time, PAI project archeologist Jennifer McWilliams and historian Kay Hindes also conducted an interview with Jerry Rambo, a longtime local resident and informant.

A geomorphology field trip to the project area was conducted June 21, 2006. Jim Abbott of TXDOT-ENV attended with PAI personnel (Boyd, Kibler, and McWilliams). Before this meeting, Kibler compiled a preliminary geomor- phic map using soil data from the Soil Survey of Menard County (U.S. Department of Agriculture 1967), geological data from the Llano Sheet, Geological Atlas of Texas (Bureau of Economic Geology 1981), and the results of the Texas A\&M University geomorphology study (Schlenker 1991). The field trip concentrated on "groundtruthing" the geomorphology map compiled by Schlenker (1991:Figure 10) and determining locations along the route where deep trenching was needed to search for buried prehistoric remains or to obtain important geomorphic evidence. Six areas where trenching was needed were identified, and these locations were plot- 
ted onto the modern aerial photograph and topographic map of the project area. Of the six areas slated for mechanical trenching, four were selected for deep trenching based on a high potential for buried prehistoric remains or to obtain important geomorphic data. One area was slated for trenching or scraping to search for possible unmarked graves identified during the historical documents review, and one trenching area was near Mission San Sabá. The six areas and their approximate lengths, as depicted in Figure 3, are:

1. Search for unmarked graves near known historic gravesite $(100 \mathrm{~m})$

2. Deep trenching in and near Harris Hollow for geoarcheology $(400 \mathrm{~m})$

3. Trenching in and around Mission Search Area at 41MN23 $(880 \mathrm{~m})$

4. Trenching near prominent swale for geoarcheology $(250 \mathrm{~m})$

5. Trenching near prominent swale for geoarcheology $(200 \mathrm{~m})$

6. Trenching on either side of Fivemile Crossing for geoarcheology $(1,250 \mathrm{~m})$

The trenching location map was then sent to Emiliano Gonzales, maintenance coordinator for TxDOT's Menard Maintenance Office. From this information, he completed the safety coordination and made appropriate requests to identify and have marked all of the buried utilities along the road right of way. Two buried utility lines were located parallel to and within $4 \mathrm{~m}$ of the south right-of-way fence, and one was located parallel to and within $3 \mathrm{~m}$ of the north right-ofway fence. Both ran the entire length of the project area. These lines were marked on the ground in all of the trenching areas before fieldwork began.

\section{REVIEW OF HISTORICAL DATA AND SPANISH COLONIAL DOCUMENTS}

The objective of the historical research was to synthesize the existing historical information pertaining to the Spanish colonial occupation and subsequent Euroamerican settlement in the San Saba River valley.
The first part of this work involved a thorough review of the following sources:

- Research files on Mission San Sabá compiled by historian Kay Hindes (San Antonio)

- Research files on Mission San Sabá and Menard Irrigation Company compiled by historian Mark Wolf (San Antonio)

- The Handbook of Texas Online, various entries

- Historical maps such as one by Callan (1901) and those on file at the Texas General Land Office

- Published volumes on the general history of Mission San Sabá, Presidio San Saba, Menard County, and the San Saba region, such as Doolittle (1995), Dunn (1914), Maestas (2003), Milford (2000), Ratcliff (1991), and Weddle (1964, 1999).

- Published archeological or historical references that pertain to Mission San Sabá or other eighteenth-century Spanish colonial settlements in Texas, such as Bolton (1914, 1970), Caran et al. (2000), Carlson (1991), Cox (2004), Gilmore (1967), Hindes et al. (1995), McWilliams (2001), and Walter et al. (2003).

- The San Sabá Papers: A Documentary Account of the Founding and Destruction of San Sabá Mission, translated and edited by Paul D. Nathan and Lesley Byrd Simpson (2000).

- Other published translations of Spanish documents pertaining to Mission San Sabá, such as Dennis (1995).

- Interview with local resident Jerry Rambo and information provided by other locals, including Dr. Jake Landers and Judge Otis Lyckman.

- Internet sites on the history of Menard County, including the TexGenWeb page and other research by Alicia Brown (2006).

- Secondary sources such as Menard County History: An Anthology (Menard County Historical Society 1982), The Free State of Menard (Pierce 1946), West Texas Frontier (McConnell, 1933), and the Texas history magazine Frontier Times. 


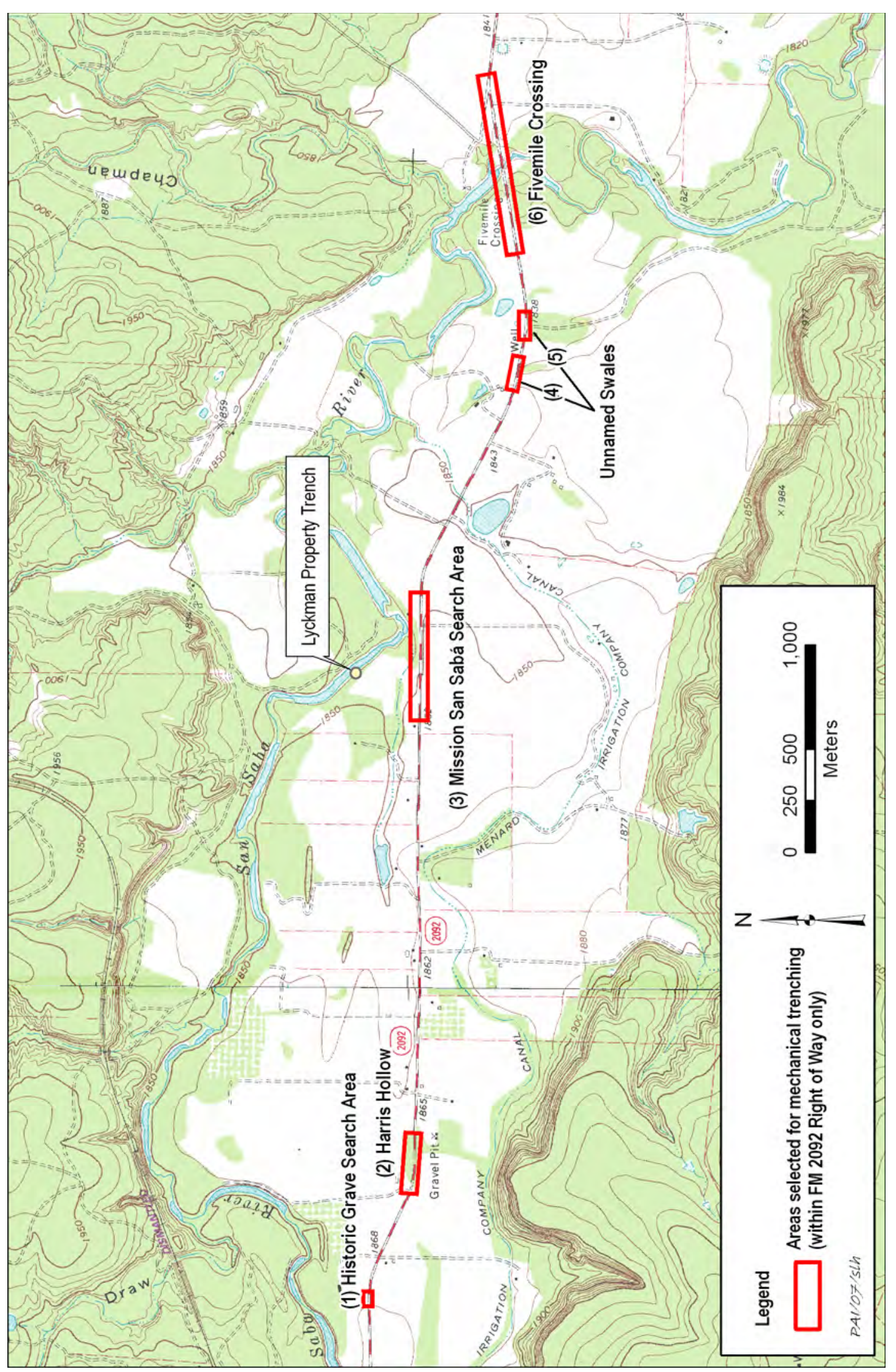

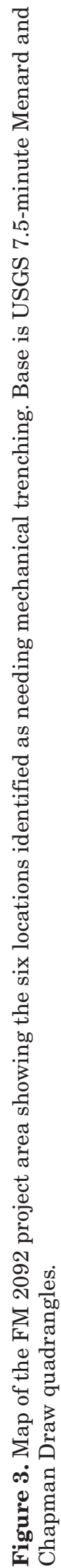


During the review of these sources, special attention was paid to identifying all comments that had relevance to possible historic resources that are known to be, known to have been, or might have been present along the FM 2092 corridor near Menard. All comments relevant to the project area were compiled in a tabulated format (Appendix A). This information was then used to compile a shorter list of definite or possible site locations of historic resources. This work identified 17 historic localities at precise or fairly precise points in or near the project area. Each of these localities was assigned a number (1 through 17) and was plotted on a modern aerial photograph (see Chapter 5). The resulting map of historic localities was used during the field survey to help guide the placement of auger tests, recording of new sites, and plotting new boundaries for previously recorded sites. The historic localities include previously recorded sites, a small cemetery, a Texas Rangers camp, historic homes and businesses, old roads, and structures. The latter locations were checked against plottings of houses on the 1954 engineering schematic for FM 2092 (Texas Highway Department 1954).
The second part of the historical research involved the translation of primary Spanish documents. At the inception of this project, PAI contracted with Spanish colonial historian Mariah Wade to conduct primary historical research. Dr. Wade reviewed more than 150 Spanish documents from various central Texas archives (primarily from the Old Spanish Missions Historical Research Collection, St. Florence Library Special Collections, Our Lady of the Lake University, San Antonio, and the Center for American History, The University of Texas at Austin). Dr. Wade transcribed and translated 10 selected documents. These documents provided more clues about the intensity of Spanish activities at the mission and along the road to the presidio. The results of this work are being published as a separate publication (Wade 2007) along with a comprehensive report on the San Sabá Mission that includes results of survey and data recovery work in the Mission Search Area (McWilliams et al. 2007). Historical research on the Menard irrigation canal was also completed. The results of this research, along with a historical overview of the Menard Irrigation System, are presented in Chapter 3. 


\section{HISTORICAL RESEARCH AND OVERVIEW OF THE MENARD IRRIGATION COMPANY}

Céline Finney and Jennifer K. McWilliams

3

As part of the project to improve FM 2092 in Menard County, Texas, Prewitt and Associates, Inc. (PAI), was contracted to conduct historical research and examine records pertaining to the historic Menard Irrigation Company Canal. The canal was recorded as archeological site 41MN21 in 1991 (Carlson 1991:74-75) and mapped on the USGS 7.5-minute Menard and Chapman Draw quadrangles (see Figure 2).

The modern Menard Irrigation Company system consists of a main canal approximately 10 miles long, beginning at a dam on the San Saba River approximately 5 miles west of Menard and ending where the canal joins the river approximately 5 miles east of town. This system was constructed beginning in 1874 , but portions of the main canal reportedly followed the abandoned acequia built by the SpaniarEEds living at Presidio San Sabá from 1757 to 1768 (Doolittle 1995; Mark Wolf, personal communication 2006; Menard Irrigation Company 2006; Pierce 1946; Lehne 1982). Although some local people have the opinion that the Menard irrigation canal does not follow any sections of the old Spanish acequia, the historical records leave little doubt that this is the case.

The nineteenth-century irrigation system is still in use and was enlarged and improved at various times. Lateral ditches have been constructed all along the main canal to channel water into privately owned fields, but no information has been found about the sequence of lateral construction. It is likely that many laterals were constructed, used, and abandoned throughout the 131-year history of the irrigation system at Menard.

This is not intended to be a comprehensive history of the Menard Irrigation Company, nor is it a thorough historic context. Rather, it is a brief history of what is now the Menard Irrigation Company, based on an examination of selected historical records, and it provides some baseline historic contextual information. To this end, a historical timeline of events pertaining to the irrigation canal was compiled (Table 2).

\section{RESEARCH METHODS}

Tasks associated with this segment of the project included a file search and literature review and preparation of a historical research and overview document. In August 2006, an architectural historian performed the file search and literature review and wrote the overview document. The literature review focused on sources that document the history of the Menard Irrigation Company, the main canal, and smaller lateral canals. Information for this segment of the project was gathered from Mark Wolf's personal research files, the General Land Office (GLO), selected articles in The Handbook of Texas Online, published secondary sources, and pertinent Internet sites. Records that were particularly informative include historical maps; primary documentation from the GLO, including a field inspection conducted in 1876; and a brochure entitled "Menard Irrigation Company" produced by the Menard Irrigation Company (2006).

Personal historic research files were obtained from Mark Wolf, a Mission San Sabá historian from San Antonio, Texas. His files contain copies from the Canal Contract No. 16 found at the GLO entitled "Menard Irrigation Company" and include an 1875 map of Vaughan's (also written Vaughn) Agricultural and Mechanical Canal (Figure 4), various other maps of the irrigation system and San Saba River system, sur- 
Table 2. Historic timeline for the Menard Irrigation Canal

\begin{tabular}{|c|c|c|}
\hline Date & Event & Source \\
\hline 1756 & $\begin{array}{l}\text { "The ditch was dug in } 1756 \text { by early Spanish Padres using } \\
\text { converted Indians for labor." }\end{array}$ & $\begin{array}{l}\text { Menard Irrigation } \\
\text { Company } 2006, * \\
\text { Pierce } 1946\end{array}$ \\
\hline 1866 & W. J. Vaughn and family settle on Elm Creek & Lehne 1982 \\
\hline 1870 & $\begin{array}{l}\text { Vaughn, Comstock, and Tipton chartered Vaughn Ditch } \\
\text { Agricultural and Mechanical Canal }\end{array}$ & $\begin{array}{l}\text { Menard Irrigation } \\
\text { Company } 2006\end{array}$ \\
\hline December 2,1871 & $\begin{array}{l}\text { Vaughn, Comstock, and Tipton chartered the Vaughn } \\
\text { Ditch Agriculatural and Mechanical Canal }\end{array}$ & $\begin{array}{l}\text { Menard Irrigation } \\
\text { Company } 2006\end{array}$ \\
\hline June 3,1874 & $\begin{array}{l}\text { "Re: Irrigation Ditch- } 2 \text { men to fix damages to Wm } \\
\text { Graham's land due to ditch construct." }\end{array}$ & $\begin{array}{l}\text { Menard County Court } \\
\text { Minutes pg } 46 \text { (Wolf } \\
\text { Research Files) }\end{array}$ \\
\hline June 22,1874 & $\begin{array}{l}\text { Court met to deal with matters of the canal in which } \\
\text { landowner Williams Graham reportedly sustained } \\
\text { "damages" to his land by way of the irrigation ditch. The } \\
\text { court found that he sustained no damages. However, later } \\
\text { ditch hands cut his fence, and Vaughn had to pay } \$ 11 \\
\text { damages. }\end{array}$ & Noguess**1946 \\
\hline July 24,1874 & $\begin{array}{l}\text { "Vaughn Ditch Agricultural and Mechanical Canal" } \\
\text { chartered was issued in Austin; W. J. Vaughn, W. J. } \\
\text { Tipton, and J. H. Comstock form a cooperative and get a } \\
\text { charter }\end{array}$ & $\begin{array}{l}\text { Pierce 1946, Lehne } \\
1982\end{array}$ \\
\hline 1874 & $\begin{array}{l}\text { Canal chartered again by Charles Shriner, J. A. Conway, } \\
\text { L. L. Russell, L. M. Chastain, J. W. Ellis, and J. L. } \\
\text { Noguess }\end{array}$ & $\begin{array}{l}\text { Menard Irrigation } \\
\text { Company } 2006\end{array}$ \\
\hline 1874 & $\begin{array}{l}\text { Vaughn built dam across the San Saba River below 4-mile } \\
\text { crossing (at Menard-Ft. McKavitt Road) }\end{array}$ & Lehne 1982 \\
\hline March 10, 1875 & $\begin{array}{l}\text { "Part of the first mile of the ditch is constructed on the line } \\
\text { of a ditch made prior to the Act of March 10th, } 1875 \\
\text { entitled 'An Act to encourage the construction of canals } \\
\text { and ditches for navigation and irrigation.'" }\end{array}$ & $\begin{array}{l}\text { Field inspection by } \\
\text { Henry C. King, } \\
\text { July } 19,1876 \text {, from } \\
\text { General Land Office } \\
\text { (GLO) records (Wolf } \\
\text { Research Files) }\end{array}$ \\
\hline July 19,1876 & $\begin{array}{l}\text { Field inspection [by Henry C. King]addressed to Governor } \\
\text { Richard Coke }\end{array}$ & $\begin{array}{l}\text { GLO records (Wolf } \\
\text { Research Files) }\end{array}$ \\
\hline August 1, 1876 & $\begin{array}{l}\text { Obstruction in the ditch is removed and an oath sworn by } \\
\text { W. J. Vaughn, J. H. Comstock, J. F. Dexter, J. C. } \\
\text { Burchin, and J. F. Harris }\end{array}$ & $\begin{array}{l}\text { Field inspection by } \\
\text { Henry C. King, } \\
\text { July } 19,1876 \text {, from } \\
\text { GLO (Wolf Research } \\
\text { Files) }\end{array}$ \\
\hline October 10,1876 & WA [sic] Vaughn appoints John Dexter as GLO agent & $\begin{array}{l}\text { GLO records (Wolf } \\
\text { Research Files) }\end{array}$ \\
\hline September 23, 1876 & $\begin{array}{l}\text { Ditch is not approved by Governor Richard Coke. "This } \\
\text { report showing the ditch to be in an unfinished condition } \\
\text { is not approved." }\end{array}$ & $\begin{array}{l}\text { Field Inspection by } \\
\text { Henry C. King, } \\
\text { July 19, 1876, from } \\
\text { GLO (Wolf Research } \\
\text { Files) }\end{array}$ \\
\hline February 2,1877 & $\begin{array}{l}\text { Ditch is "examined and approved as a ditch of the fourth } \\
\text { class..." }\end{array}$ & $\begin{array}{l}\text { Field inspection by } \\
\text { Henry C. King, } \\
\text { July } 19,1876 \text {, from } \\
\text { GLO records (Wolf } \\
\text { Research Files) }\end{array}$ \\
\hline 1880 & $\begin{array}{l}\text { "Otto Kordzik, a German immigrant from Prussia, used a } \\
\text { section of the ditch that was dug by the Spaniards and } \\
\text { Indians to operate a gristmill }\end{array}$ & $\begin{array}{l}\text { Menard Irrigation } \\
\text { Company } 2006\end{array}$ \\
\hline 1886 & $\begin{array}{l}\text { Gus Noyes came to Menard from Maine. He acquired } 56 \\
\text { shares of stock in the canal }\end{array}$ & Pierce 1946 \\
\hline
\end{tabular}


Table 2, continued

\begin{tabular}{|c|c|c|}
\hline Date & Event & Source \\
\hline 1890 & $\begin{array}{l}\text { Noyes built a dam (ca. } 18 \mathrm{ft} \text { deep) at the mouth of the } \\
\text { canal }\end{array}$ & $\begin{array}{l}\text { Menard Irrigation } \\
\text { Company 2006; } \\
\text { Pierce } 1946\end{array}$ \\
\hline December 28, 1891 & William J. Vaughn died & Noguess 1946 \\
\hline August 4, 1904 & $\begin{array}{l}\text { Canal was chartered again; Gus Noyes bought the canal } \\
\text { from Vaughn "at a cost of } \$ 10,000 \text { " }\end{array}$ & $\begin{array}{l}\text { Menard Irrigation } \\
\text { Company } 2006\end{array}$ \\
\hline 1905 & "Menard Irrigation Company" chartered & Pierce 1946 \\
\hline 1946 & $\begin{array}{l}\text { N. H. Pierce, author of The Free State of Menard, was the } \\
\text { president of the Menard Irrigation Company, and } \\
\text { T. C.Thaxton was the secretary }\end{array}$ & Pierce 1946 \\
\hline 1975 & $\begin{array}{l}\text {...a "sag-culvert" flow system was installed to replace the } \\
\text { old flume at Las Moras Creek. }\end{array}$ & $\begin{array}{l}\text { Menard Irrigation } \\
\text { Company } 2006\end{array}$ \\
\hline 2003 & $\begin{array}{l}\text { LCRA and Caroline Runge had three stream gauges or } \\
\text { water monitors }\end{array}$ & $\begin{array}{l}\text { Menard Irrigation } \\
\text { Company } 2006\end{array}$ \\
\hline
\end{tabular}

* Menard Irrigation Company (2006) is a brochure produced and distributed by the Menard Irrigation Company, Menard, Texas.

**Mrs. Whittie Vaughn Noguess was the daughter of Williams J. Vaughn and wrote "Founder's Daughter Gives Her Version" in The Free State of Menard, by Pierce (1946).

veys, deeds to the agricultural and mechanical district company, court minutes, a field inspection and notes, an index to deed records, and notes from a phone interview with Chet Haley, former president of the Menard Irrigation Company. The majority of items in Mr. Wolf's files are copies of original records dating from ca. 1875 to ca. 1886.

A review of Menard Irrigation Company records at the GLO was conducted on August 6, 2006, but this work revealed no new data other than that previously compiled by Mark Wolf (in the Canal Contract No. 16 file, Menard Irrigation Company). Céline Finney, architectural historian for PAI, made copies of two historic maps of the irrigation district. With the help of a GLO archivist, Finney determined that no further information pertaining to the Menard Irrigation Company existed at the GLO. In addition, no information pertaining to Gus Noyes, the man who purchased the irrigation canal from W. J. Vaughan in the 1880 s, was on file. The archivist commented that 11 certificates were issued but never delivered to the GLO, and it is speculated that many of the records that document the early history of the irrigation system were originally in the possession of the Menard Irrigation Company but were thrown out when the company's former president, Chet Haley, passed away in 2004 (Kniffen 2006). At present, no new information pertaining to the irrigation company and any improvements or additions to the irrigation system after 1880 has been located. Local informants Katherine Kniffen (current officer) and Jake Landers (on the current board of directors) were consulted to fill in gaps in the historic record.

\section{"THE LIFE-BLOOD OF AGRICULTURE" OF THE SAN SABA VALLEY}

William J. Vaughan came to Menard County in 1866 (Lehne 1982). Realizing the potential a canal held for irrigating fields, as well as attracting settlers, he decided to channel the waters of the San Saba River and persuaded James W. Comstock and William J. Tipton to join the venture (Lehne 1982). A brochure published by the Menard Irrigation Company states that Vaughan, Comstock, and Tipton chartered the Vaughan Ditch Agricultural and Mechanical Company in 1870, and the deed for this purchase was filed on December 2, 1871 (Menard Irrigation Company 2006). However, most sources state that the company was chartered on July 24, 1874, to channel water from the San Saba River "commencing five miles above the town of Menardville and to extend 20 miles below the town" for the purposes of agricultural irrigation, various mill operations, and mechanical uses (Menard Irrigation Company 2006; 


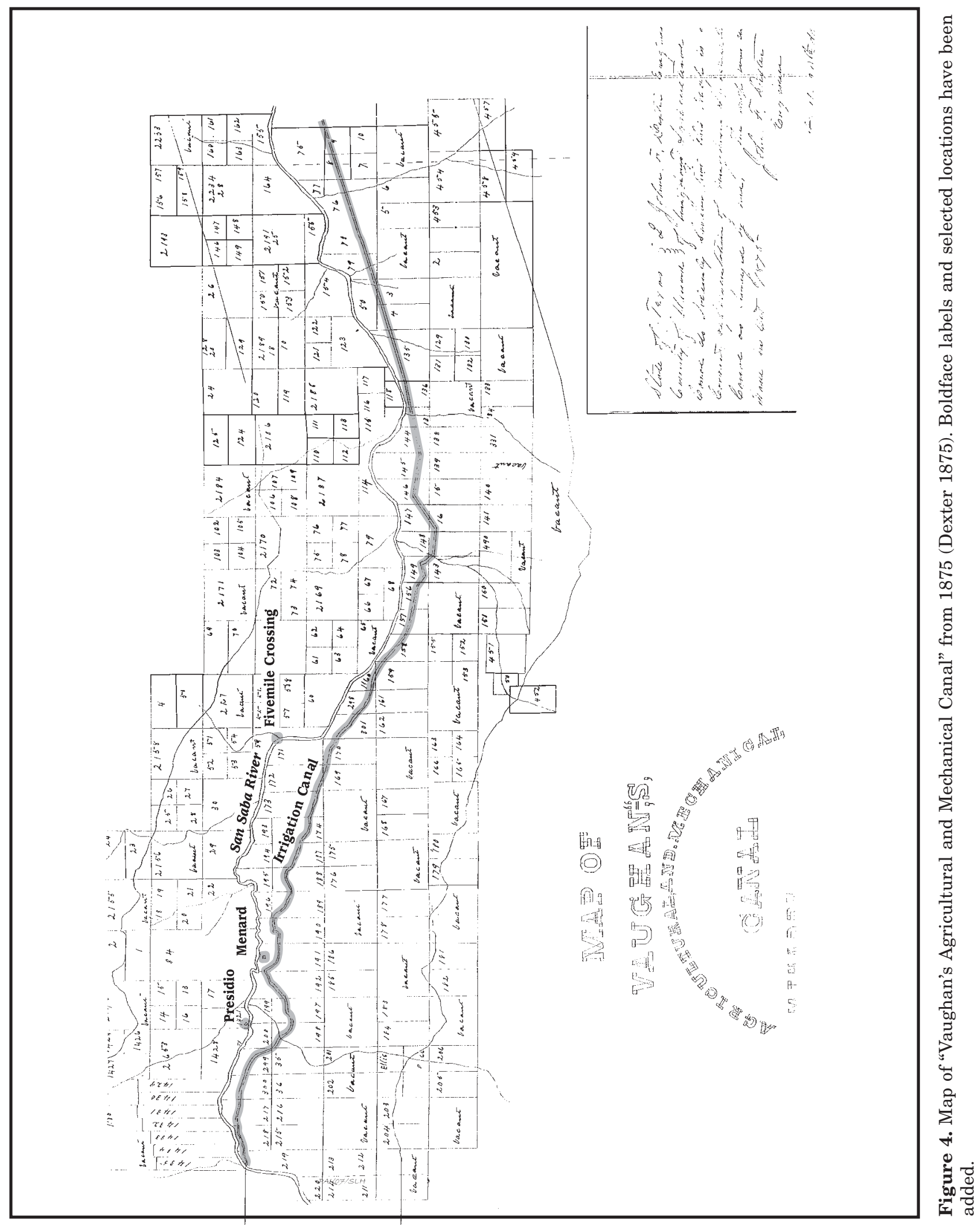


Pierce 1946:21). Again, there is some confusion in the records because a second charter was then issued to Charles Shriner, J. A. Conway, L. L. Russell, L. M. Chastain, J. W Ellis, and J. L. Noguess at an unknown date (Menard Irrigation Company 2006). However, no records of these names appear in the GLO files.

Clearly, the original plan of the canal was approximately 15 miles longer than the modernday canal, and the original proposed canal was intended to extend to the Menard-Mason county line (see Figure 4). Vaughan's original canal only went 2 miles east of town (Pierce 1946). The license to operate the irrigation canal was $\$ 20$ per year (Menard Irrigation Company 2006). Capitol stock in the company was fixed at $\$ 50,000$, and 100 shares were issued (Pierce 1946:21; Noguess 1946:23).

Construction of the dam and ditch began in 1874. Vaughan's crew used picks, shovels, and eventually added a scraper or slip pulled by a team (Lehne 1982; Noguess 1946). However, there were problems with the initial layout of the ditch. Apparently, Vaughan hired a less than reliable surveyor (records do not indicate the name of the original surveyor), and approximately 1 mile of excavated ditch line was not effective (Noguess 1946:22; Lehne 1982:18). This surveyor was replaced by John F. Dexter (Noguess 1946:22), who surveyed the ditch route and compiled a detailed map and notes (Dexter 1875a; 1875b; Figure 5). Henry C. King, a field inspector, explained that the ditch was "more costly than usual, owing to engineering difficulties" (1876:n.p.).

Additional difficulties included at least one court case involving William Graham, a landowner west of Menard, who did not approve of the "destruction" crossing his land (Noguess 1946; Lehne 1982; Menard County Court Records, June 3, 1874). Eventually, the canal was put through his land, but he got his revenge when "ditch hands" cut Graham's fence. Graham charged Vaughan $\$ 11$ for repairs to his fence (Noguess 1946:23).

Captain Dan Roberts, who oversaw the Texas Rangers in Menard from 1875 to 1878 and later at Fort McKavett in 1878, describes the evolution of government subsidies to irrigation projects and the Rangers' role in the irrigation ditch:

When the Republic of Texas came into the Union of the States, she reserved all her public domain, and appropriated it to the upbuilding of the state, in public institutions and school funds. And "Uncle Sam" was not more liberal in giving the people homes. I think it was the Fourteenth Legislature [13 January 1874 to 15 March 1875] that offered land subsidy, to encourage irrigation, specifying the dimensions of a ditch to carry the water, say six feet wide, at the bottom of the ditch, and twelve feet wide, from cut to cut across the top, and four feet deep, on level ground. For this class of ditch, the state offered three sections of land to the mile of ditch, not otherwise appropriated, to the makers of that grade of ditches. The state not reserving any rental, or any further claim on the enterprise. Under this covenant, between the state and the citizen we had the pleasure of seeing the first ditch made, and stood guard for the workers in their happy vocation [Roberts 1987:85].

On July 19, 1876, a field inspection was conducted and recorded by King (transcribed by Mark Wolf in the Wolf Research Files). King served as the "Commissioner of Canals and Ditches West of the Colorado River" under Governor Richard Coke (to whom the field inspection was addressed) and under Governor R. B. Hubbard (Rouse 2001).

In his report, King (1876:n.p.) describes the first mile of the ditch as being

...constructed on the line of a ditch made prior to the Act of the $10^{\text {th }}$ March, 1875, entitled "An Act to encourage the construction of canals and ditches for navigation and irrigation"...that part of the ditch...is $1458 \ldots$ varas in 


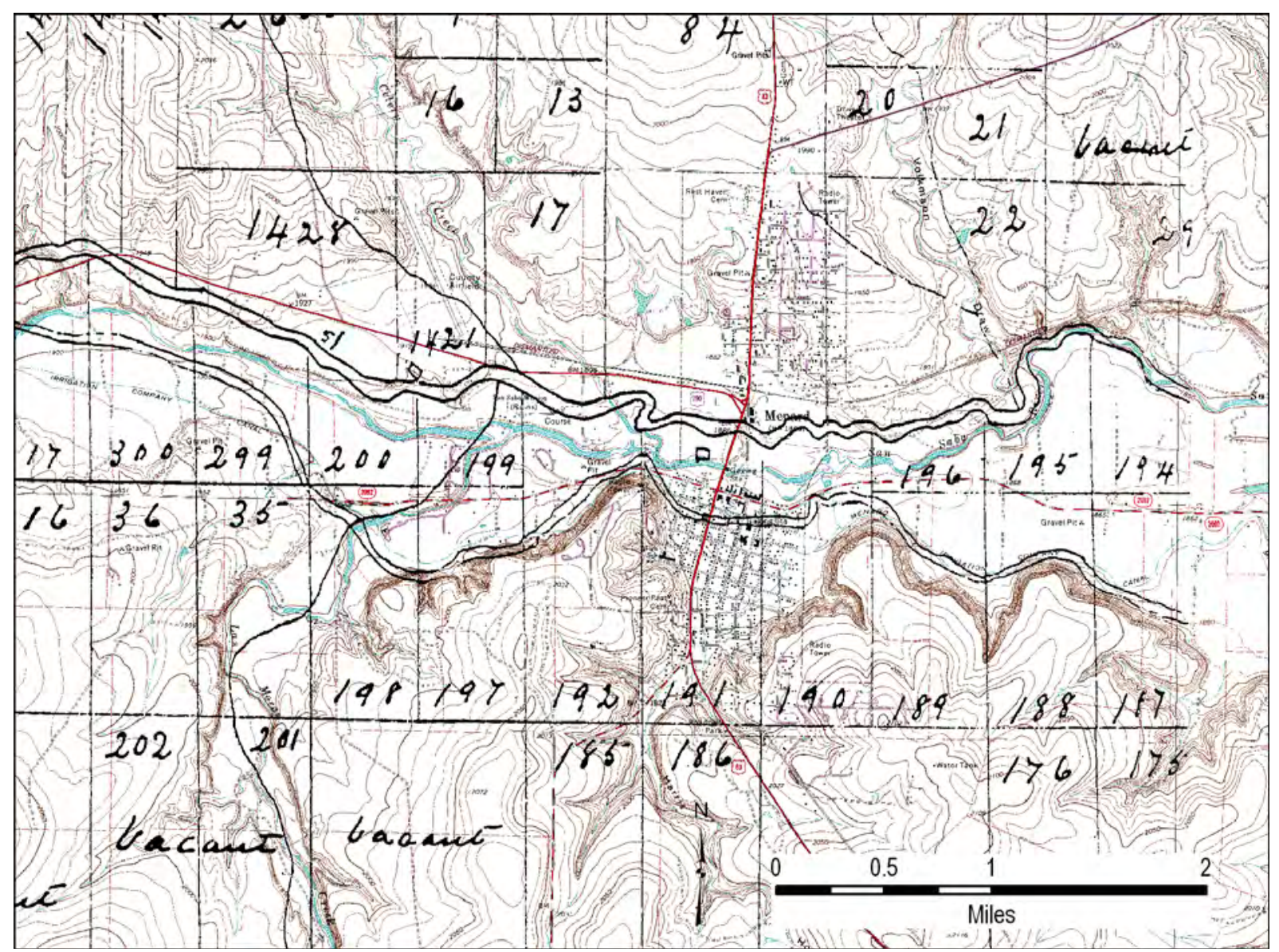

Figure 5. Comparison of the 1875 map of Vaughan's Agricultural and Mechanical Canal (Dexter 1875a) with modern topography in the vicinity of Menard, Texas (U.S. Geological Survey, Menard quadrangle 1987a, 1987b).

length. From the best information that I can obtain, the old ditch has saved the Company about one forth the work of construction.

It is likely that this mention of "the old ditch" refers to the Spanish acequia.

At the time of the 1876 initial inspection, the ditch was 4 miles long. The ditch appears to have passed the inspection with the exception of a rock obstruction found in the last eighth of the final (forth) mile of the ditch. King (1876:n.p.) reported:

The company stated to me that their supply of blasting powder being exhausted and being unable to procure any short of the interior towns, they had been compelled to leave these rocks until the powder arrived. They stated that they expected to take these pieces of rock the following week after the inspection. The rocks do not entirely obstruct the flow of water, and the ditch may be used without removing them. The general character of the work, however, and it's prospective usefulness seem to guaranty the removal of these obstructions.

However, on September 23, 1876, Governor Richard Coke did not approve the ditch, stating "this report show $[\mathrm{s}]$ the ditch to be in an unfin- 
ished condition is not approved" (Field Inspection 1876:n.p., Wolf Research Files). On October 10, 1876, Vaughan appointed John H. Dexter [sic] (probably the same as surveyor John "F" Dexter) to be the agent to the General Land Office (GLO documents, Wolf Research Files). A few months later, King advised the Governor that the rock had been removed, and the ditch finally passed inspection on February 2, 1877. On March 5, 1877, the company received $\$ 5,000$ in bonds for the canal for a 10-year period (Field Inspection 1876, Wolf Research Files).

A description of the Vaughan Agricultural and Mechanical Company was filed with the GLO on June 11, 1875, by Rhoads Fisher, chief clerk (GLO document, Wolf Research Files). This document was transcribed by Mark Wolf as follows:

\section{Description of the Vaughan AM Co.}

Said ditch is cut on the south side of the San Saba River, commencing opposite the mouth of the Coglin [Creek] at Cave Spring Branch, Whence said co. have erected their dam. Said Dam is constructed at dam of rock and brush. The dimensions of said dam are as follows:

\{to wit\} length $420 \mathrm{ft}$, average width $40 \mathrm{ft}$ average height $3 \frac{1}{2}$ feet. The first mile of said ditch is of an average depth of $3^{1 / 2} \mathrm{ft}$ and on average depth of $6 \mathrm{ft}$. General course being NNE At the terminus of the $1^{\text {st }}$ mile the San Antonio and Fort Concho Road crosses. A bridge having been erected of plank and timber $18 \mathrm{ft}$ in width and $12 \mathrm{ft}$ long.

The 2nd mile of the ditch is an average of $3 \mathrm{ft}$ and of an average (sic) width of $6 \mathrm{ft}$.

General course northeast The $3^{\text {rd }}$ mile of said ditch of an average depth of $3 \mathrm{ft}$ and $6 \mathrm{ft}$ wide. $520 \mathrm{ft}$ on the $1^{\text {st }}$ quarter of the $3^{\text {rd }}$ mile is to be a levee or aqueduct as is necessary to raise the water $4 \mathrm{ft}$ above the ground.

On the last quarter of the $3^{\text {rd }}$ mile the San Antonio-Fort Concho Road crosses upon a bridge to be built of plank and timber to be supported [by] abutments (sp) of stone. Said bridge is to be $18 \mathrm{ft}$ wide and $12 \mathrm{ft}$ long.

100 yards below said bridge the water is to be conducted across Howard's Creek [now Las Moras Creek] in an aqueduct or flume to be built of plank resting on abutments of stone at each bank and supported by spileing (?) in the center.

The dimensions of said aqueduct are as follows:

\{to wit\} Length $125 \mathrm{ft}$ width $6 \mathrm{ft}$ depth $2 \frac{1}{2} \mathrm{ft}$ said aqueduct is $10 \mathrm{ft}$ above the water in Howard Creek.

The $4^{\text {th }}$ mile of ditch is of an average depth of $3 \mathrm{ft}$ and of an average width of $6 \mathrm{ft}$ and the general course being east.

The $1^{\text {st }}$ quarter of the $5^{\text {th }}$ mile will average $4 \mathrm{ft}$ deep and $7 \mathrm{ft}$ wide, and the other $3 / 4$ of the same to be $3 \mathrm{ft}$ deep and $6 \mathrm{ft}$ wide. The town of Menardville is situated $4 \frac{1}{2}$ miles below the head of the said ditch.

The remainder of the above described ditch to average $6 \mathrm{ft}$ in width and $2 \frac{1}{2} \mathrm{ft}$ deep. The general course is ENE.

In 1886, engineer Gus Noyes moved from Maine to settle in Menard. Seeing the possibilities of irrigation in the area, he quickly obtained 56 of the 100 available shares and interested others to join him in continuing the development of the canal and irrigation system. He built a dam across the river in about 1890. On August 4, 1904, Noyes purchased the company from J. W. Vaughan, the son of William J. Vaughan. The elder Vaughn died in 1891, having never used water from the canal to irrigate his land, although he reportedly had "sunk" $\$ 12,000$ into its construction (Noguess 1946:23). His widow 
bought water from Noyes at the going rate of $\$ 2$ per inch per acre for 10 years. Mrs. Whittie Vaughn Noguess, the daughter of William J. Vaughn, stated that Noyes also dug the canal deeper and "changed the course of the old chartered line, about 200 yards east of the west line of the old Arnet Tipton survey of land and made what he called a surface ditch" (Noguess 1946:23). This change in the route avoided Vaughan's land, preventing him from using the water. Noguess's note suggests that Tipton surveyed some portion of the early line or that Noyes had access to the Tipton survey for his new line.

Noyes employed approximately 100 workers, and within two years the canal totaled 8 miles through the valley. These workers probably lived in the community of Sunnyside, ca. 4 miles east of Menard on FM 2092. In 1991, Carlson recorded three historic sites (41MN5, $41 \mathrm{MN} 9$, and $41 \mathrm{MN} 10$ ), including the Noyes homesite, remains of other homesites, a cotton gin, a historic artifact scatter, and a dump. However, additional information suggests that these sites represent a community or tent camp that was the home to workmen for Noyes's farm and cotton gin (Smyrl 2001) as well as the "ditch hands." More information on Sunnyside is provided in Chapter 5.

In 1905, Noyes formed the Menard Irrigation Company, and the system irrigated about 2,000 acres in the San Saba River valley. Noyes reportedly profited $\$ 20,000$ per year from his irrigation "projects" (Menard Irrigation Company 2006), suggesting that he may have had other endeavors besides the one at Menard. Once a steady supply of water was established, the valley was able to produce cotton, corn, oats, potatoes, melons and "garden truck" produce (Noguess 1946:25). The normal ditch flow in 1904 was 17.5 cubic feet per second (Menard Irrigation Company 2006).

Vaughan died on December 28, 1891, having "sunk" $\$ 12,000$ into the endeavor (Noguess 1946). Vaughan never irrigated his land with the water from the canal. His widow bought water from Noyes at the going rate of $\$ 2$ per inch per acre for 10 years (Noguess 1946). After 30 successful years operating the irrigation system, Noyes sold his interest in the canal (Pierce 1946:21) in about 1935.

Throughout the twentieth century, the main canal and subsequent lateral ditches irrigated fields along both sides of what is now FM 2092. The canal remains in use today and is operated by the Menard Irrigation Company in Menard. Currently 20 shareholders participate in the irrigation canal, and dues increased from $\$ 100$ to $\$ 150$ in 2003 . Each shareholder is allotted $4 \frac{1}{2}$ hours of water, which runs on a 17 -day cycle (Menard Irrigation Company 2006). A "sag-culvert" was installed in 1975 to replace the old flume at Las Mores Creek, and $\$ 90,000$ was spent on updates between 2000 and 2003 (Menard Irrigation Company 2006). The portion of the historic canal that runs through town is locally known as "The Ditch," and the scenic "Ditch walk" has become a tourist attraction for the community of Menard (Menard Irrigation Company 2006).

\section{EARLY HISTORY OF THE MENARD IRRIGATION CANAL}

When construction of the original system began, some sections of the main canal reportedly followed the abandoned acequias built by the Spaniards living at Presidio San Saba from 1757 to 1768 (Doolittle 1995; Mark Wolf, personal communication 2006; Haley 1995; Pierce 1946; Lehne 1982). Pierce (1946:20) supports the theory in his article entitled "Spaniards Built First Irrigation Ditch." But he also states that the original functions of the acequia were: (1) to "provide some means of transporting rock across the stream, to be used in building rock walls of the presidio and compound"; and (2) to irrigate the fields using lateral ditches. Pierce goes on to explain that the Spanish built rafts to float the rock across the river. However, this is not likely the case; they probably built the acequias for the sole purpose of irrigation.

Four pieces of evidence support the theory that the Menard Irrigation Canal follows the route of the Spanish acequia: (1) Dexter's 1875 field notes mention "Spanish Ditch"; (2) Dexter's 1875 survey map and the USGS map line up with where the Spanish ditch are thought to converge; (3) Callan's 1901 map mentions the old irrigation system; (4) Chet Haley said that the "present ditch did make use of Spanish acequia."

Dexter's field notes and survey map (1875a; $1875 b)$ confirm that the irrigation canal followed the Spanish acequia for some distance (see Figure 5). Starting at Cogden Creek (also called 


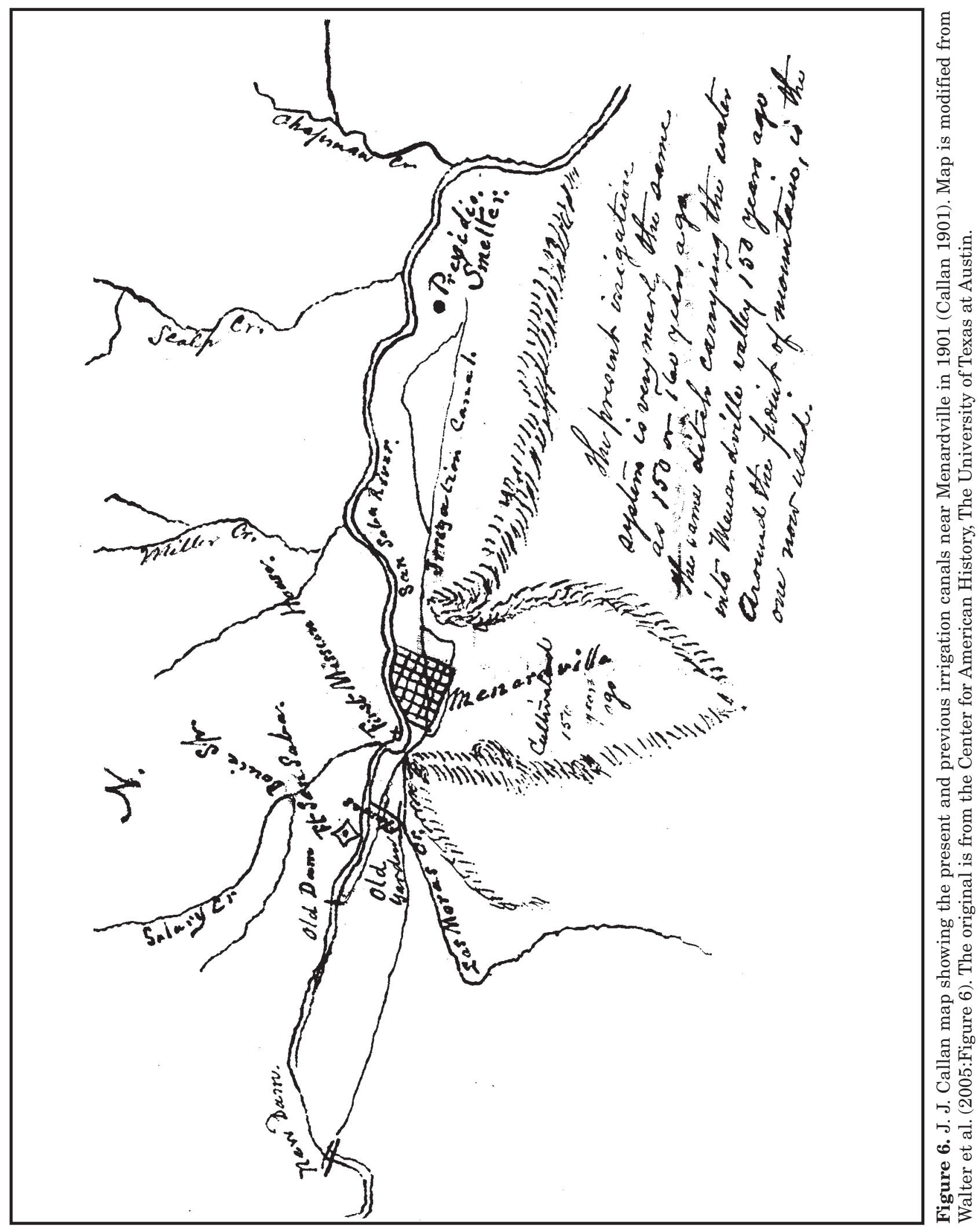


Coghlan in some sources), ca. 4 miles west of town, Dexter measured in 36-vara-lengths (100 ft or 1 chain), taking measurements from survey corners. For a distance of $1,714 \mathrm{ft}$, he wrote "Mountain - - Side," indicating that the canal followed around the north side of the bluffs on the west side of Menard. Then at 4,385 ft, he wrote, "Point Mountain/Old Spanish Ditch." The point at which the canal intersected the "Old Spanish Ditch" is about half a mile southwest of the Presidio San Sabá. Apparently, the canal followed the Spanish acequia for an unknown distance but at least $806.4 \mathrm{ft}$.

Judge J. J. Callan provided many clues to the route and history of the canal in a 1901 map he enclosed in a letter regarding inquiries about the Mission San Sabá (Figure 6). In the map, Callan depicts the San Saba River valley and the canal running from the "new dam" (probably Noyes's 1890 dam), running through Menard and ending east of town near the confluence of Scalp Creek, just east of the mission site. Callan annotated the map with the following statement: "The present irrigation system is very nearly the same as 150 or 160 years ago. The same ditch carrying the water into Menardville valley 150 years ago around the point of mountain, is the one now used." Callan's map clearly shows the irrigation canal converging with a canal that flows from the "old dam" just west of "Fort San Saba"-interpreted as the Spanish acequia—at the point along the bluffs just west of the town of Menard. He shows a second canal coming off the main canal and running south and east through the town of Menard, and explains in his annotation that this area was "cultivated 150 years ago." Continuing eastward, the map shows the canal heading east out of Menard and converging with a third canal that appears to correspond with the location of Harris Hollow on modern topographical maps. Finally, the canal ends near the site of Mission San Sabá with the words "Presidio Smelter." This suggests that Callan (and possi- bly his contemporaries) interpreted the mission site as a smelter for the presidio, perhaps because they observed large amounts of burned daub and metal artifacts there.

Mark Wolf interviewed Chet Haley, the former Menard Irrigation Canal president, in 1995. Haley, who was 80 years old at the time, reported that at one time the ditch ran through town north of San Saba Street. He confirmed three facts: (1) that the "ditch did make use of [the] Spanish acequia"; (2) that at one time, the ditch flowed below Noyes's cotton gin (then on the McDaniels Place) and crossed the river on the east side; and (3) that two to three gristmills and a cotton mill once operated along the ditch, but the "State came through and forbid [the] generation of power" from the irrigation canal (Haley 1995). Haley's records were lost after his death and are thought to be the 11 boxes for which space was reserved at the General Land Office.

\section{FIELD DOCUMENTATION OF THE MENARD IRRIGATION SYSTEM COMPONENTS}

During the FM 2092 archeological survey by PAI in July 2006, five segments of the irrigation system were photodocumented where they pass beneath FM 2092. These segments include one road crossing of the main canal, which is mapped on the USGS 7.5-minute Menard and Chapman Draw quadrangles, and four road crossings of smaller laterals. During the field survey, black-and-white and digital color photographs were taken of each ditch location that was within or near the FM 2092 right of way. This work was not intended as a comprehensive historic resources reconnaissance, and it does not provide all necessary information to support a full evaluation of the irrigation system. However, the photographs do document the sections of the system that are within the stateowned right of way (see Chapter 5). 


\title{
ARCHEOLOGICAL SURVEY OF FM 2092 FROM MENARD TO FIVEMILE CROSSING
}

\author{
Jennifer K. McWilliams and Douglas K. Boyd
}

The investigation of 4.7 miles of FM 2092 (excluding the ca. 400-m-long Mission Search Area) focused on re-locating and reevaluating previously recorded sites and identifying new sites within the road right of way. Work began with a pedestrian survey, mechanical augering, and backhoe trenching. A gradall was also used in one area. This was followed by shovel testing in selected areas. Excavations to expose and sample the subsurface deposits along the 4.7mile-long stretch of FM 2092 included 13 backhoe trenches, 1 gradall trench, 50 auger tests, and 26 shovel tests.

Pedestrian survey was conducted by walking the road right of way, both north and south of the road, and visually inspecting all areas where ground exposures were good. Although the edges of the roadway had been recently mowed, most of the right of way was covered in dense grasses so that the survey had to rely on subsurface testing. Prehistoric sites were discovered by the presence of surface artifacts in some areas that had minimal vegetation cover.

The backhoe and gradall were only used in areas delineated for mechanical trenching where buried utilities had been precisely marked (see Figure 3). A Bobcat equipped with a 12-inch-diameter auger was used to dig tests in the bottoms of the borrow ditches in lieu of shovel tests. Both auger tests and trenches were plotted on aerial photographs as they were dug, and UTM coordinate locations were also recorded using a handheld Garmin GPS LX. The survey and mechanical testing were followed by shovel testing in selected areas.

In general, a no-collection policy was used for the archeological survey of the FM 2092 project corridor, but selected diagnostic specimens were surface collected from one site (41MN55). Flakes found in auger and shovel tests were recorded in the field but not collected.

Survey and subsurface testing within the FM 2092 right of way included examination of many unrecorded historic locations, previously recorded sites, and areas near previously recorded sites. This work also included subsurface

Table 3. Summary of excavations for the FM 2092 project area

\begin{tabular}{lcccc}
\hline \multicolumn{1}{c}{$\begin{array}{c}\text { FM 2092 Survey } \\
\text { Type of Test }\end{array}$} & $\begin{array}{c}\text { (excluding the } \\
\text { mission area) }\end{array}$ & $\begin{array}{c}\text { Mission San Saba } \\
\text { Area* }\end{array}$ & Private Property* & Total \\
\hline Backhoe Trench & 13 & 0 & 1 & 14 \\
Gradall Trench & 1 & 19 & 0 & 20 \\
Auger Test & 50 & 0 & 0 & 50 \\
Shovel Test & 26 & 6 & 0 & 32 \\
Test Unit $(1 \times 1 \mathrm{~m})$ & 0 & 8 & 0 & 8 \\
Test Unit $(50 \times 50 \mathrm{~cm})$ & 0 & 3 & 0 & 3 \\
\hline Total & 90 & 36 & 1 & 127 \\
\hline
\end{tabular}

* These excavations are discussed in a separate report on the excavations at Mission San Sabá. 
Table 4. Summary of mechanical and hand excavations in the FM 2092 project area by site and area proveniences*

\begin{tabular}{|c|c|c|c|c|c|c|}
\hline $\begin{array}{l}\text { Site Number or } \\
\text { Location }\end{array}$ & Site Type or Location & $\begin{array}{l}\text { Backhoe } \\
\text { Trenches }\end{array}$ & $\begin{array}{c}\text { Gradall } \\
\text { Trenches }\end{array}$ & $\begin{array}{c}\text { Auger } \\
\text { Tests }\end{array}$ & $\begin{array}{c}\text { Shovel } \\
\text { Tests }\end{array}$ & Test Units \\
\hline \multicolumn{7}{|c|}{ Previously Recorded Sites } \\
\hline $41 \mathrm{MN5}$ & $\begin{array}{c}\text { Historic and } \\
\text { prehistoric }\end{array}$ & & & & & \\
\hline $41 \mathrm{MN} 9$ & $\begin{array}{c}\text { Historic and } \\
\text { prehistoric }\end{array}$ & & & & & \\
\hline $41 \mathrm{MN} 10$ & Historic & & & & & \\
\hline 41MN11 & Prehistoric & 2 & & & & \\
\hline $41 \mathrm{MN} 12$ & $\begin{array}{c}\text { Historic and } \\
\text { prehistoric }\end{array}$ & & & & & \\
\hline $41 \mathrm{MN} 13$ & Historic & & & & & \\
\hline $41 \mathrm{MN} 15$ & $\begin{array}{c}\text { Historic and } \\
\text { prehistoric }\end{array}$ & & & 8 & 3 & \\
\hline $41 \mathrm{MN} 20$ & Historic & & & 3 & 3 & \\
\hline $41 \mathrm{MN} 21$ & Historic & & & & & \\
\hline $41 \mathrm{MN} 23$ & $\begin{array}{l}\text { Historic (Spanish } \\
\text { Mission) and } \\
\text { prehistoric }\end{array}$ & & 19 & & 6 & 11 \\
\hline \multicolumn{7}{|c|}{ Newly Recorded Sites } \\
\hline $41 \mathrm{MN} 53$ & $\begin{array}{c}\text { Historic and } \\
\text { prehistoric }\end{array}$ & 1 & & 1 & & \\
\hline $41 \mathrm{MN} 54$ & $\begin{array}{c}\text { Historic and } \\
\text { prehistoric }\end{array}$ & 1 & & & & \\
\hline 41MN55 & Prehistoric & 1 & & & & \\
\hline 41MN56 & Prehistoric & & & 4 & 6 & \\
\hline 41MN57 & Prehistoric & & & 2 & 4 & \\
\hline 41MN58 & Prehistoric & & & 1 & 4 & \\
\hline 41MN59 & Prehistoric & & & 2 & 3 & \\
\hline $41 \mathrm{MN} 60$ & $\begin{array}{c}\text { Historic and } \\
\text { prehistoric }\end{array}$ & & & 3 & 3 & \\
\hline $41 \mathrm{MN} 61$ & $\begin{array}{c}\text { Historic and } \\
\text { prehistoric }\end{array}$ & & & 3 & & \\
\hline \multicolumn{7}{|l|}{ Nonsite Areas } \\
\hline $\begin{array}{l}\text { West end of } \\
\text { project area }\end{array}$ & Harris Hollow & 3 & & 10 & & \\
\hline $\begin{array}{l}\text { West end of } \\
\text { project area }\end{array}$ & Tull grave search area & & 1 & & & \\
\hline $\begin{array}{c}\text { Central end of } \\
\text { project area }\end{array}$ & None & & & 6 & & \\
\hline $\begin{array}{l}\text { East end of } \\
\text { project area }\end{array}$ & Unnamed swale & 1 & & & & \\
\hline $\begin{array}{l}\text { East end of } \\
\text { project area }\end{array}$ & & 4 & & 7 & & \\
\hline $\begin{array}{l}\text { Private property, } \\
\text { east end }\end{array}$ & None & 1 & & & & \\
\hline \multicolumn{2}{|l|}{ Total } & 14 & 20 & 50 & 32 & 11 \\
\hline
\end{tabular}

*No artifacts were collected from excavations except at Mission San Sabá, 41MN23. 
testing of site and nonsite areas using backhoe trenching, gradall trenching, auger testing, and shovel testing (Tables 3 and 4).

Table 5 summarizes all of the recorded sites in and near the FM 2092 project area, and their locations are shown in Figure 7. During the survey, eight of the previously recorded sites were found to be outside the project area and between $100 \mathrm{~m}$ and $700 \mathrm{~m}$ away from the road. The right of way was also inspected for 10 previously recorded sites, and archeological remains were found associated with 5 of these. The survey also discovered and documented 9 new sites. Of the 19 sites known to be adjacent to or extend into the FM 2092 right of way, 4 are historic, 6 are prehistoric, and 9 have both historic and prehistoric components.

\section{SUMMARY OF BACKHOE TRENCHING}

Before fieldwork, six investigation areas were determined to need mechanical trenching, and four areas were slated for backhoe trenches (see Figure 3). Backhoe excavations began at Harris Hollow, near the western end of the project area, and moved eastward through the project area. Trenches were $0.8 \mathrm{~m}$ wide, ranged from 6 to $12 \mathrm{~m}$ long, and generally reached depths of 1.5 to $2 \mathrm{~m}$. Appendix B presents descriptions of geologic profiles for selected trenches.

Backhoe Trenches 1-3 were placed within and on either side of the swale at Harris Hollow. Backhoe Trenches 4-6 were placed in the vicinity of an unnamed swale about $1 \mathrm{~km}$ west of Fivemile Crossing. Backhoe Trenches 7-10 were placed in the Holocene alluvial terrace ca. 200-400 m west of Fivemile Crossing. Backhoe Trench 11 was placed on a higher Pleistocene surface east of the San Saba River. Finally, Backhoe Trenches 12 and 13 were placed near the eastern end of the Mission Search Area, about 150-250 m east of the location of Mission San Sabá. No prehistoric or historic remains were found in any of the trenches, although Backhoe Trenches 5 and 6 were dug in prehistoric sites as indicated by surface evidence (see Chapter 5 for 41MN54 and 41MN53).

Harris Hollow is a prominent swale that runs from west to east down the San Saba River valley. Because of the agricultural landscaping, this broad swale holds running water during large rainfall events. There are many stock ponds along the hollow, and numerous electrical pumps line the bottom. Local informants say that the water table in Harris Hollow is only $15 \mathrm{ft}$ deep. Backhoe Trench 1 was dug in the bottom of Harris Hollow, and Trenches 2 and 3 were dug on the west and east sides of the swale, respectively. Trench 1 revealed a dense zone of channel gravels (most fist-sized and smaller) at $158 \mathrm{~cm}$ below surface, overlain by fine-grained alluvium. No gravels were found in the other trenches, but Trench 1 stratigraphy clearly indicates that Harris Hollow was once a large stream, presumably a former channel of the San Saba River. The stratigraphic profile of Backhoe Trench 1 (see Appendix B), examined by geomorphologist Karl Kibler, indicates that this channel has been abandoned for some time. Two soil humate samples were taken on the overlying clayey deposits, and they were submitted to Beta Analytical for radiocarbon dating. The resulting assays and interpretations are reported in a subsequent publication (McWilliams et al. 2007).

\section{SUMMARY OF GRADALL TRENCHING}

Nineteen gradall trenches were excavated in the Mission San Sabá Search Area, but these are discussed in a subsequent publication (McWilliams et al. 2007). The gradall was used in only one other location along FM 2092, in the vicinity of the Tull Smith gravesite (see Historic Localities 1-4 in Chapter 5). Because there was one known and several possible historic graves located $25 \mathrm{~m}$ north of the road, and they were inside a tree motte that comes within $10 \mathrm{~m}$ of the road, the possibility of additional graves associated with the small cemetery or unmarked graves was high. A mechanical grave search was conducted. A 15-m-long gradall trench was dug in the borrow ditch north of FM 2092, directly south of the tree motte where the graves are located. The trench could not be excavated closer to the north right-of-way fence because of a buried utility line, and it could not be excavated closer to the road because of the thickness of the artificial fill forming the road base. The trench was excavated to a depth of $40-50 \mathrm{~cm}$, and homogenous intact clayey sediment was encountered. At this depth, any grave shafts would have been visible, but none were found. The grave locations were not recorded as a historic site because they 
Survey of FM 2092 from Menard to Fivemile Crossing

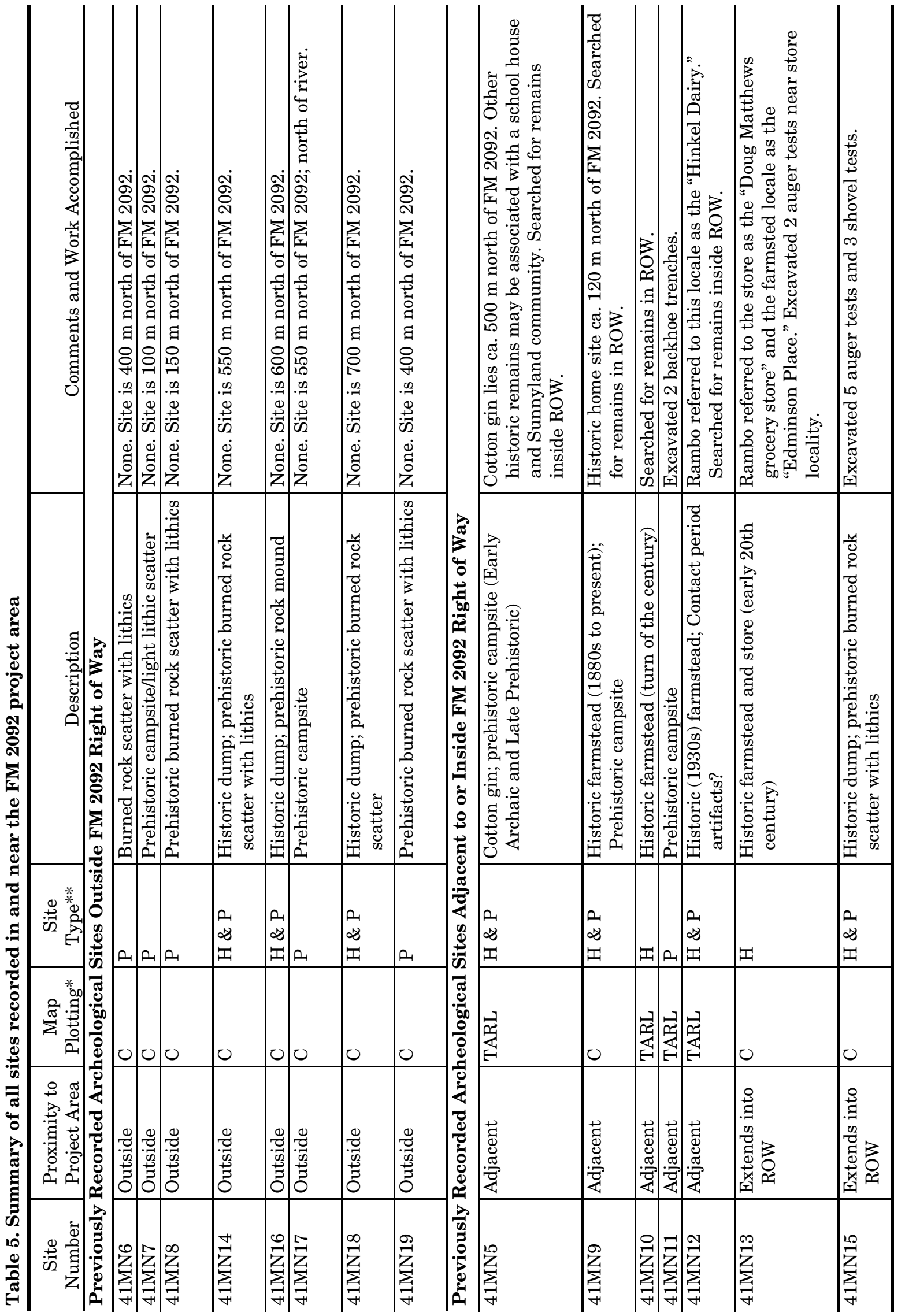


Chapter 4: Archeological Survey of FM 2092

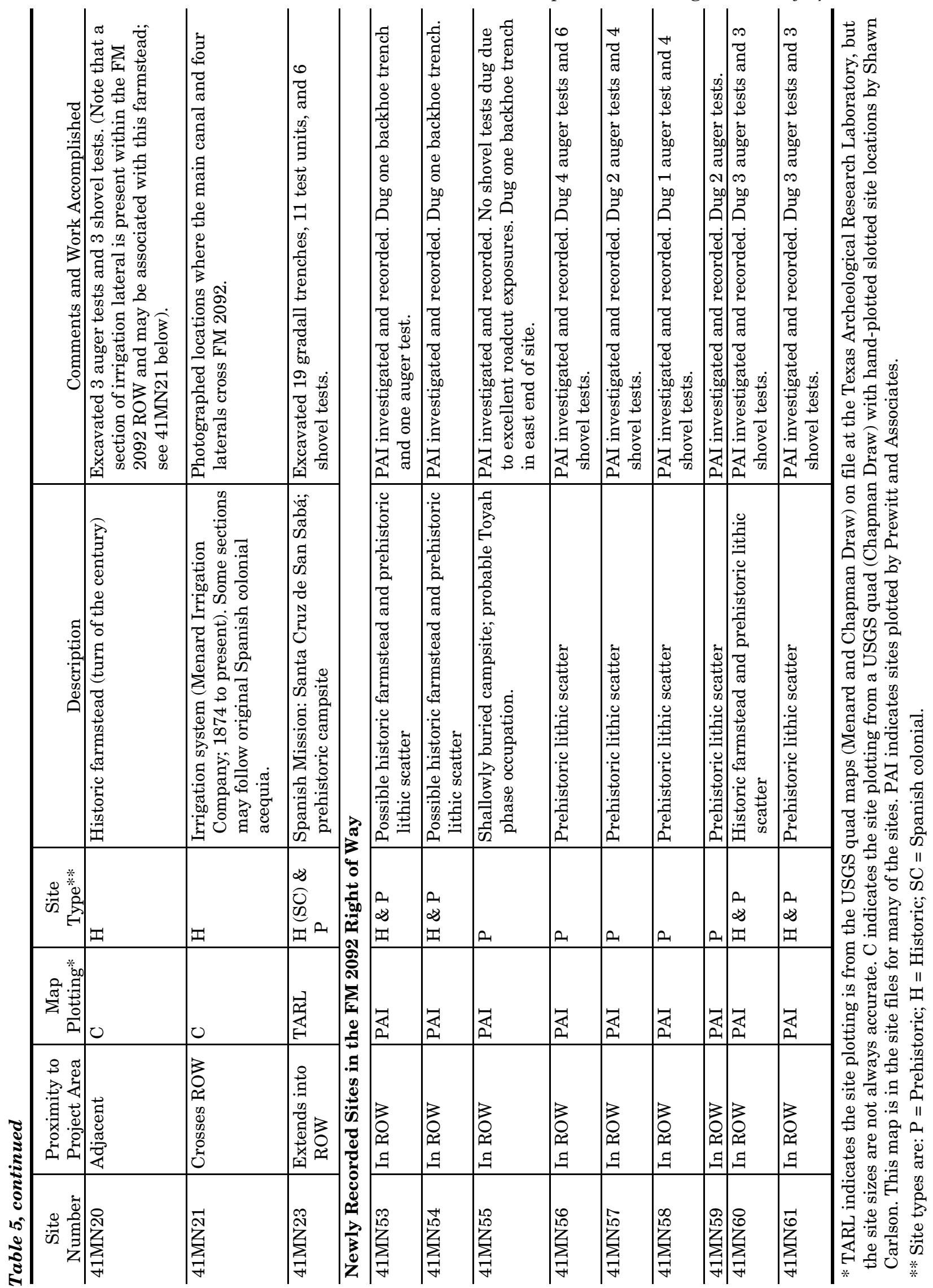





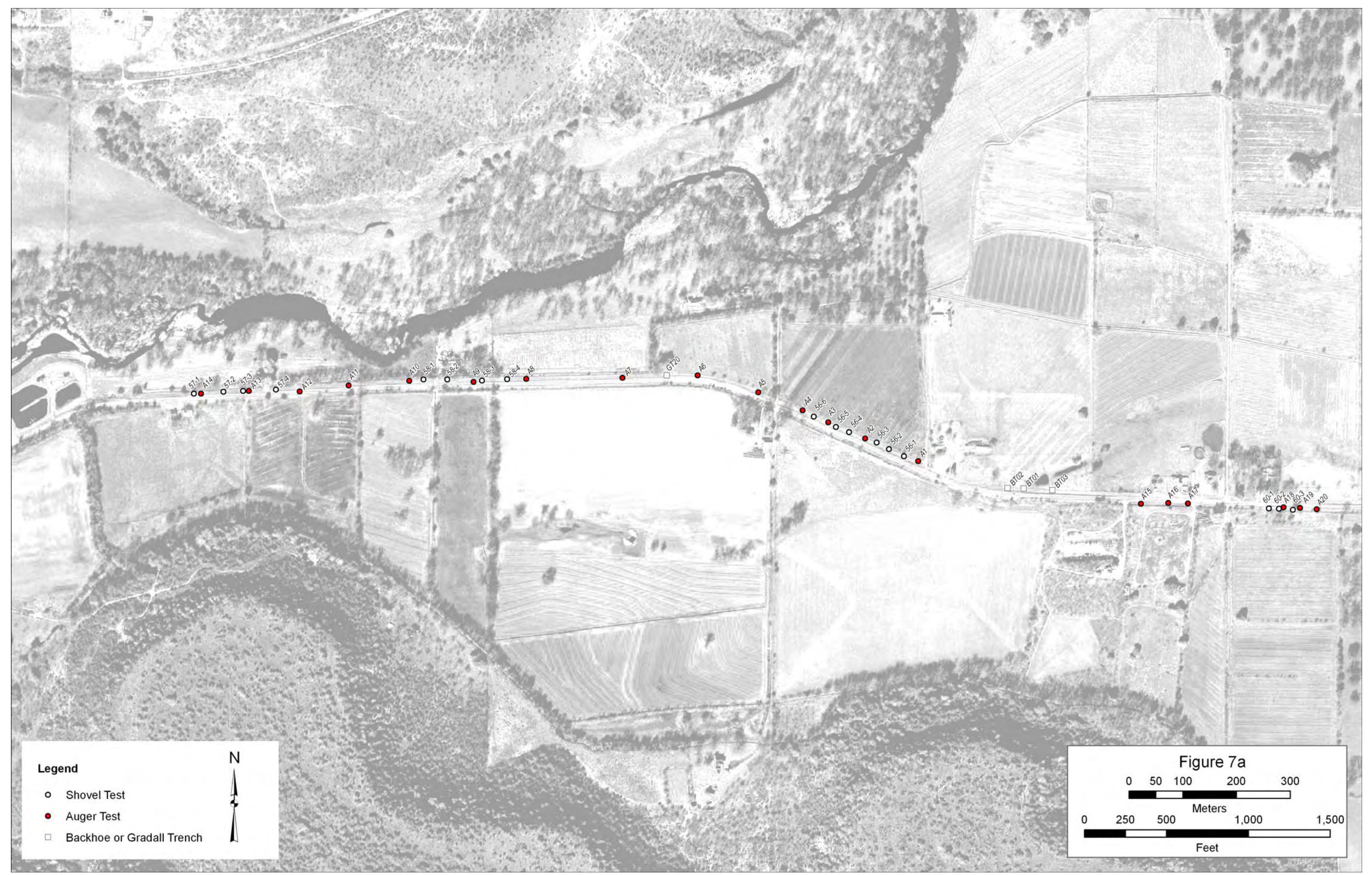

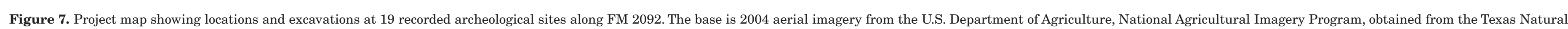
Resources Information System. Note: Figure 7 is in three parts designated as 7a $7 \mathrm{~b}$, and 7c, from east to west. 


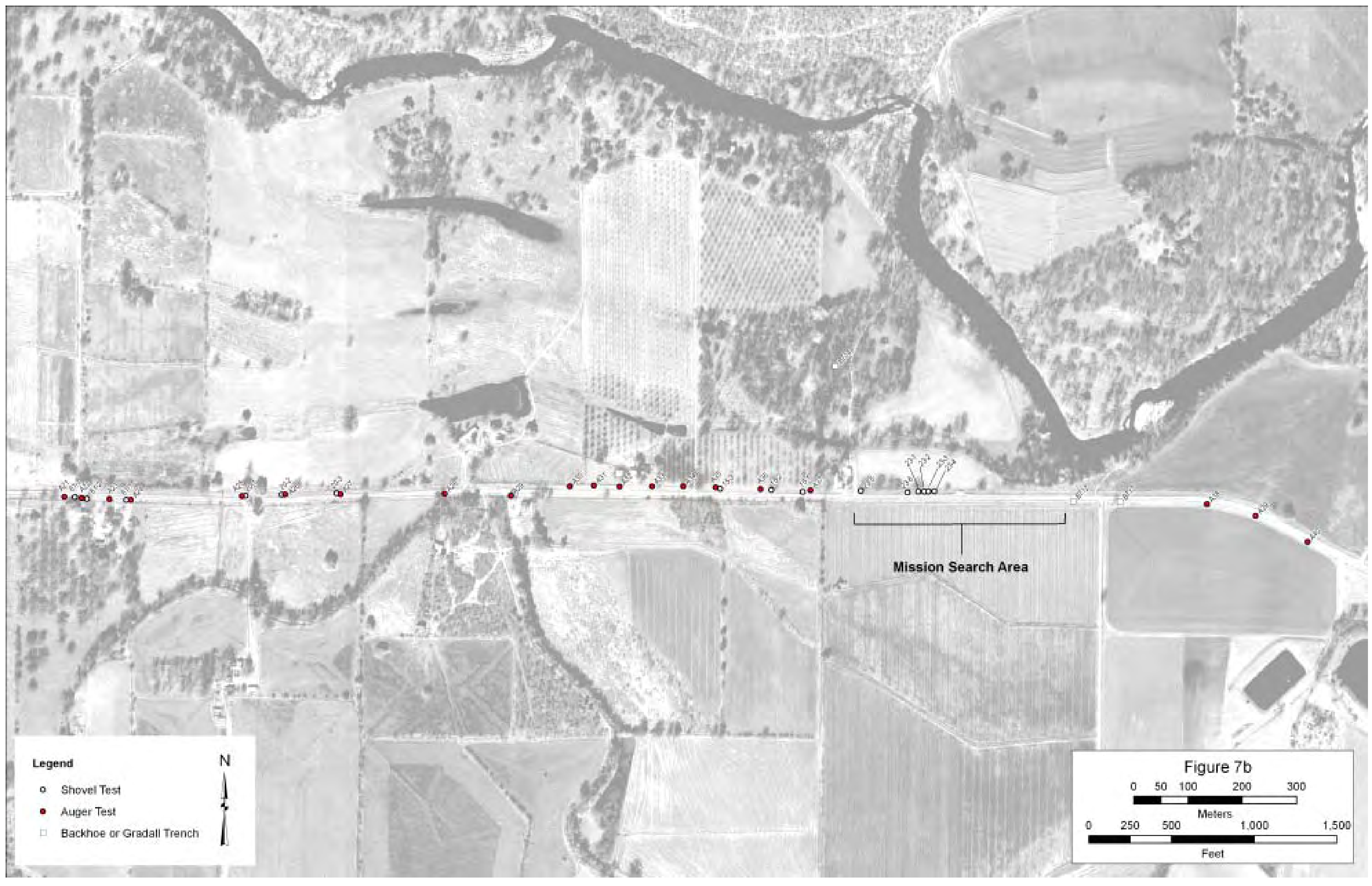




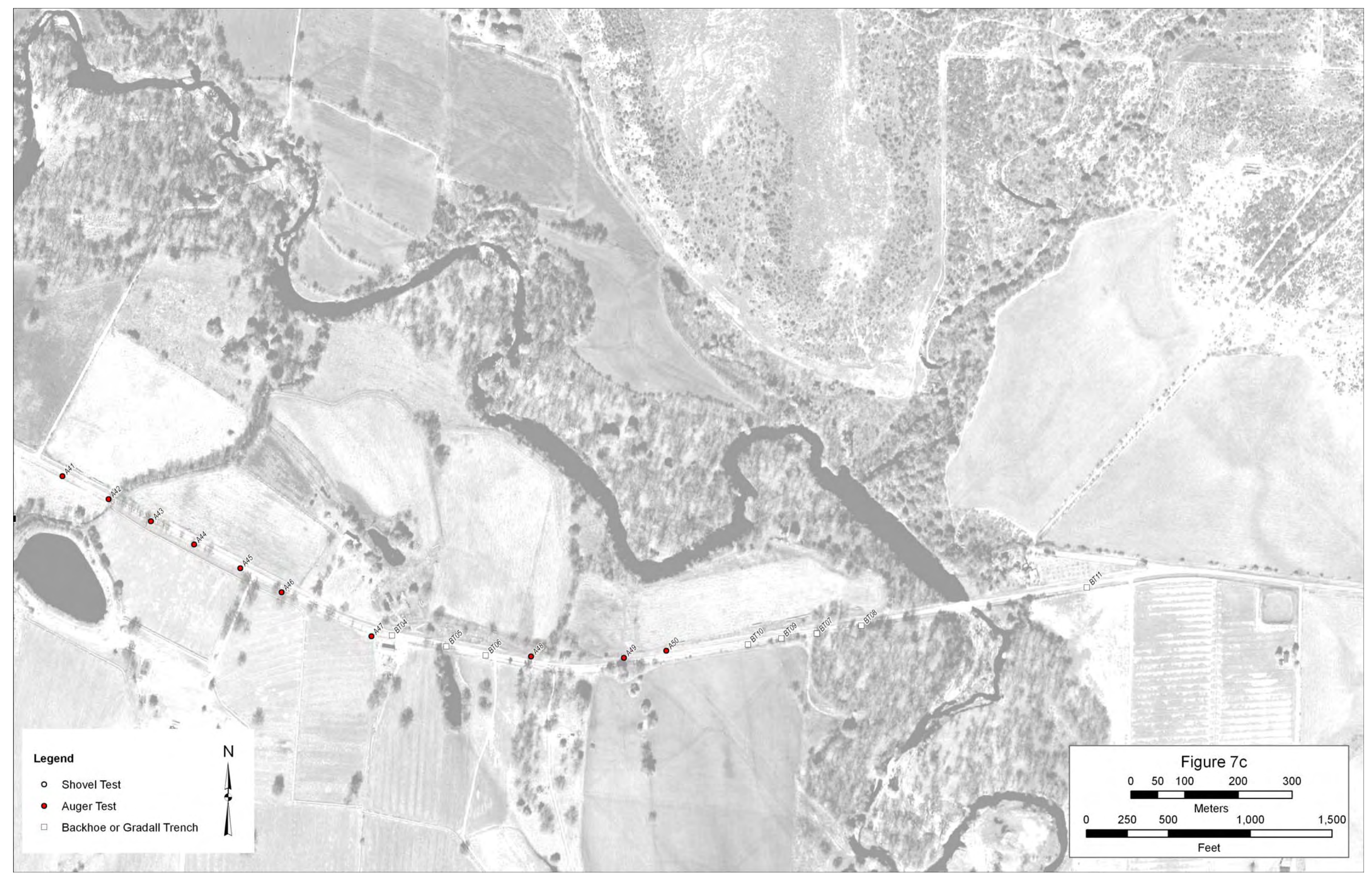


were outside the project area and did not extend into the FM 2092 right of way.

One backhoe trench was excavated on private property, with permission from the landowners, Monte and Suzie Lyckman. This trench was dug across a section of abandoned irrigation lateral ditch not far from the Mission San Sabá site to determine if the historic irrigation lateral might follow an old Spanish acequia near the mission. The evidence suggested that this was not the case. The details of this investigation are presented in a separate report on archeological investigations at Mission San Sabá (McWilliams et al. 2007).

\section{SUMMARY OF AUGER TESTING}

Fifty auger tests were excavated with a Bobcat equipped with a 16-inch-diameter auger attachment (see Appendix C). Each test was approximately $40 \mathrm{~cm}$ in diameter, and they were dug to depths ranging from 28 to $114 \mathrm{~cm}$. Auger testing was stopped at a depth where dense gravels or bedrock was encountered or at a depth of approximately $100 \mathrm{~cm}$. Most were dug to 70 to $100 \mathrm{~cm}$ below surface. In order to avoid the buried utility lines that were within 3 to $4 \mathrm{~m}$ of the right-of-way fences, auger tests had to be dug in the half of the right of way closest to the paved road. This meant that they were either in the middle of the borrow ditch (if there was one) or just upslope toward the road. Because there was often a layer of gravelly artificial fill along the roadway, dense gravels sometimes prevented the auger from digging deep enough to sample the underlying deposits.

Auger tests were dug as a single unit because separation by levels was not possible. Matrix was piled off to one side of the auger hole and screened through a 1/4-inch hardware mesh screen. Stratigraphic observations were made while the auger excavation was being conducted. Each auger test was plotted on an aerial photograph, stratigraphic observations were noted, and recovery of artifacts was recorded on an Auger Test Record Form. Unmodified flakes were the only artifacts observed in auger tests, and since no diagnostic artifacts were found, nothing was collected.

Auger testing began immediately west of Harris Hollow (see Figure 3) and moved westward. When this area was completed, auger testing continued east of Harris Hollow and moved to the east throughout the remainder of the project area. Auger tests were numbered consecutively throughout the project area. Auger tests were generally spaced out about $100 \mathrm{~m}$ apart. However, when an auger test yielded artifacts, additional auger tests or shovel tests would be dug nearby to provide a better sample of the materials.

Two problems were encountered with the unmodified debitage found in auger testing. One was determining the depths that flakes originated from, and the other was determining whether or not they were really flakes. Attempts to determine the depth where these artifacts originated proved difficult in most cases. Auger test profiles commonly exhibited an upper ca. $20 \mathrm{~cm}$ of artificial gravelly road fill, followed by pale brown to dark brown loam, silty loam, or clay loam with small to medium gravels intermixed. At times, larger gravels were found at deeper depths. As the auger tests were dug, it was usually difficult to tell where any particular flake might have been originally. It is notable that the 1954 FM 2092 engineering schematic (Texas Highway Department 1954) shows at least five quarries near the road-improvement project that were used to collect gravel for fill base. Thus, it is clear that much of the road base added for FM 2092 was from local gravel sources, and the materials would be indistinguishable from those in natural gravels.

Because of the gravelly nature of the soils and the presence of artificial gravels, chert nodules and broken pieces of chert were common. It appears likely that several different processes introduced pseudo artifacts. Plowing of the agricultural fields, including areas now within the road right of way, undoubtedly broke some of the natural chert nodules and created "artifacts." Next, gravelly road base was introduced when the county road was built and maintained, and again when FM 2092 was built in the 1950s. During initial construction and subsequent maintenance episodes, heavy machinery certainly broke chert nodules and created "road artifacts." Finally, "auger artifacts" were created during this archeological project when the mechanical auger hit chert nodules, especially as it was grinding through dense layers of artificial gravels. While it was often possible to identify these pseudo artifacts, it was not obvious in some cases. While some auger tests produced 
flakes that were unmistakably of prehistoric origin, others produced flakes of uncertain origin. This was an issue in some of the shovel tests as well (see below), but the better vertical control enabled more confidence in determining the origins of the flakes. However, one could not assume that a flake was a prehistoric artifact simply because it was found in the underlying clay deposits, because it was common to find isolated nodules and broken cobbles deep in drying cracks in the clayey alluvium. Because of this uncertainty, the archeologists often labeled the auger test records with qualifiers such as "possible" and "probable" when recording lithic debitage counts. Airing on the conservative side, auger tests were only considered to be positive if an unmistakable flake was present or if multiple flakes were found.

Of the 50 auger tests excavated, 31 were placed near previously recorded sites or in areas where new sites were discovered. These auger tests are discussed in Chapter 5. The remaining 19 auger tests were excavated in areas where no sites were previously known. They produced no archeological remains. The off-site auger tests are briefly described below.

Auger Tests 5 and 6 were placed $15 \mathrm{~m}$ and $150 \mathrm{~m}$ west of the Historic Graves Search Area (see Figure 3), and Auger Tests 7 and 8 were placed $46 \mathrm{~m}$ and $180 \mathrm{~m}$ east of the grave area. These reached depths ranging from 70 to $93 \mathrm{~cm}$ below surface and exposed road gravels over grayish brown silty loam. Auger Tests 10-12 were placed between 41MN57 and 41MN58 at the western end of the project area (see Figure 3). Auger Test 10 reached $40 \mathrm{~cm}$ and exposed pale pinkish brown silty loam with gravels. Auger Tests 11 and 12 reached 100 and $90 \mathrm{~cm}$ below surface and exposed brown silty clay loam with gravels.

Auger Tests 15-17 were dug north of a whitewashed stone well house located just outside of the right of way. These were placed to test for historic materials associated with a possible historic farmstead that may have extended into the right of way. A 1-m roadcut here truncated the site within the right of way. These tests reached $65-90 \mathrm{~cm}$ and exposed pale pinkish brown to light brown silty loam with dense gravel well below surface deposits. Two to three possible flakes were recovered from each of these auger tests, but they are not considered to be prehistoric due to the depths and contexts where they were found. They are most likely flakes brought in with road fill or created through gravel damage by road maintenance or auger testing.

Auger Tests 38-46 were dug in the southern right of way near the eastern end of the project area. These reached $61-87 \mathrm{~cm}$, with the exception of Auger Test 41, which only reached $30 \mathrm{~cm}$. These exposed gravelly brown silty loam. Auger Test 40 recovered an isolated core. Auger Test 42 recovered one sherd of whiteware with blue glaze and three iron fragments (probably associated with the irrigation ditch crossing). Auger Test 43 recovered one possible flake, one mussel shell fragment, and one aqua bottleneck fragment. Auger Tests 44, 45, and 46 recovered 2 possible flakes each. This area was surveyed intensively, but no surface artifacts were observed, other than light scatters of modern and recent historic debris, probably associated with highway-related trash. Because no distinct concentration of materials could be defined, no site was recorded here. It is likely that these light surface scatters of lithics are the result of road maintenance, plowing, and gravel quarrying over the years and are not prehistoric deposits.

\section{SUMMARY OF SHOVEL TESTING}

Thirty-two shovel tests were excavated during the survey phase of fieldwork along FM 2092. All shovel tests excavated during the survey were placed on either previously recorded or newly recorded sites (see Appendix C). Shovel tests were $30 \mathrm{~cm}$ in diameter and were dug in $20-\mathrm{cm}$ levels. Matrix was screened through 1/4inch hardware mesh. Soil stratigraphy and artifacts were recorded on a Shovel Test Record Form. Unmodified flakes and one core were the only definite artifacts found in shovel tests, and since no diagnostic artifacts were recovered, nothing was collected. Most shovel tests were placed in the vicinity of positive auger tests where definite or probable prehistoric artifacts were recovered. The shovel tests were used to establish the vertical distribution of historic and prehistoric artifacts, and in some cases to confirm that flakes found in the auger tests were actually prehistoric artifacts. The shovel tests also helped establish the site boundaries for previously recorded and newly recorded sites. 


\title{
ARCHEOLOGICAL SITES AND HISTORIC LOCALITIES RECORDED ALONG FM 2092
}

\author{
Jennifer K. McWilliams
}

Prior to this survey, 22 archeological sites were recorded in the general vicinity of the project area, 19 of which fall along this segment of FM 2092 east of Menard (see Table 1; Figure 3). These include six prehistoric sites, one Spanish colonial site (41MN23, Mission San Sabá), three nineteenth-century historic sites, eight that contain both nineteenth-century and prehistoric components, and one that contains both nineteenth-century and probable Spanish colonial components (41MN21, irrigation canal). The site of Presidio San Sabá is 41MN1, and its location has long been known. All of the other sites were recorded after 1990 .

Texas A\&M University conducted an archeological survey of a portion of the San Saba River valley around Menard in 1990, and the results of this study are reported by Carlson (1991). This survey was conducted primarily to search for the archeological remains of Mission San Sabá. Although they were able to narrow down the search area for the missing mission, they did not find the site. The survey did, however, record 18 archeological sites (41MN5 through 41MN22) scattered across the San Saba River valley, primarily east of Menard.

In conjunction with the 1990 Texas A\&M survey, Schlenker (1991) conducted a preliminary geoarcheological study of a 5-mile-long section the San Saba River valley east of Menard. This study documented several landforms in the valley (including an alluvial fan, old and young alluvial terraces, active floodplain, and active channel) and identified some old river channel locations based on subsurface exposures (see Schlenker 1991:Figures 10-15). Schlenker (1991:Table 1) also documented many high-velocity flood events from 1899 to 1977. In addition, historian Martha Doty Freeman

(1991:Figure 24) located a 1913 county surveyor map showing that a portion of the San Saba River channel (in the eastern end of the FM 2092 project area) was in a different location than it is today. Collectively, these studies indicate that the San Saba River was a dynamic river system and that the potential for well-preserved buried prehistoric or historic deposits in different alluvial settings is very high.

\section{PREVIOUSLY RECORDED SITES IN THE FM 2092 RIGHT OF WAY}

Ten previously recorded archeological sites are adjacent to or within TxDOT right of way along FM 2092 (see Table 1). These sites are described below, including setting, previous work, summary of the current investigations, observed cultural materials, horizontal and vertical extent of cultural deposits, and assessment of site type and research potential. All 10 of the previously recorded sites are discussed below, even if no cultural remains were found within the TxDOT right of way during this survey.

\section{MN5, Sunnyside Community (see also 41MN10)}

Originally recorded by Carlson in 1991, $41 \mathrm{MN} 5$ consisted of three distinct historic artifact scatters, remnants of a cotton gin, and a prehistoric lithic scatter that produced Early Archaic and Late Prehistoric diagnostics (1991:54). At that time, the historic component was interpreted as a farmstead associated with the cotton gin. Carlson (1991:54) states, "The scatter nearest State Highway 2092 had the greatest density and no doubt represents the house site while the other two [scatters] may 
have been outbuildings." Artifacts observed were indicative of household and farm-related activities.

The lithic scatter was observed as a concentration on a slight mound in the center of the field and included cores, blades, gravers, retouched flakes, rough bifaces, tested and untested chert cobbles, burned limestone, and at least four keeled end scrapers. A piece of possible daub was also observed. The presence of possible daub at this site close to the mission is interesting. Although daub could certainly be from a prehistoric or historic Indian occupation, daub was the most common material found in the cultural deposits at Mission San Sabá (Hindes et al. 1995:55-61), only $0.7 \mathrm{~km}$ to the west.

Current historical research revealed that the community of Sunnyside was located here in the 1880s. The community consisted of a cotton gin, a store, and a school (Smyrl 2001), although homes or a tent camp was probably also present. The settlement was established for workers of the Gus Noyes farm (Smyrl 2001). Since Noyes came to Menard in 1886 (Pierce 1946:21) and employed approximately 100 men to extend the irrigation canal in the $1890 \mathrm{~s}$ (Menard Irrigation Company 2006), it is possible that this settlement may have housed the workers.

Jerry Rambo (personal communication 2006) reported that his father attended school in Sunnyside (interpreted to possibly be around the 1920s). The community does not appear on the 1936 or 1958 Menard County Highway maps (Texas Highway Department 1936, 1958), but is further described in the context of the irrigation canal (see Chapter 3).

Carlson's hand-drawn map found in the TARL site files shows the site extending ca. $150 \mathrm{~m}$ along the northern FM 2092 right of way, roughly between Rambo Lane and the crossing of the irrigation canal near the east-central portion of the project area. Historic artifacts were found on the southern side of the right of way in Auger Test 42 but were associated with the irrigation ditch crossing. Disturbances within the right of way may have removed artifacts along FM 2092. Although no artifacts were observed within the right of way along this portion of FM 2092, a TexSite archeological site revisit form was filed at TARL explaining the probable history of the site.

\section{MN9}

Carlson recorded 41MN9, the Gus Noyes farmstead, in 1991. The site consists of an original structure atop a limestone-lined basement thought to be constructed in the 1880 s or 1890 s, a spring-fed tank, irrigated fields, and a prehistoric lithic scatter. The home has been modified significantly. Carlson excavated six shovel tests and recovered nondiagnostic historic artifacts that appeared to be consistent with a late-nineteenth-century occupation. A light scatter of prehistoric artifacts suggests a few short Native American occupations.

On Carlson's hand-drawn map found in the TARL site file, the site spans ca. $175 \mathrm{~m}$ along FM 2092. No cultural materials were observed along the FM 2092 right of way. Because no cultural materials were found, no further work was conducted at this site, and no site revisit form was completed.

\section{MN10, Sunnyside Community (see also 41MN5)}

Carlson also recorded 41MN10, a historic farmstead, in 1991. Household and architectural artifacts were observed as well as a low rockstrewn mound thought to be the remains of a house or possibly a stone corral and dump. Artifacts consisted of bottle glass, stoneware, transferware, and related household artifacts that Carlson interpreted to date to a turn-ofthe-century occupation. Based on the physical relationship of sites, common artifact assemblage, and historic documentation, 41MN5 (Sunnyside Community) and 41MN10 may both represent portions of a tent-camp community of Sunnyside. Further investigations into the historic community may clear up the confusion.

On Carlson's hand-drawn map found in the TARL site file, the site appears immediately west of Rambo Lane and spans ca. $75 \mathrm{~m}$ along the FM 2092 right of way. No historic artifacts were observed in the right of way. Because no cultural materials were found in the right of way, no further work was done at this site, and no site revisit form was completed.

\section{MN11}

Carlson recorded 41MN11, a burned rock scatter with lithics, in 1991. The site follows the 
southern banks of the San Saba River immediately east of the mission site. A sparse scatter of burned rocks, chert flakes, and rough tools was observed at the time of recording.

On Carlson's hand-drawn map found in the TARL files, the southern end of the site extends to FM 2092, spanning ca. $100 \mathrm{~m}$ along the right of way. Several chert cobbles and flakes were observed in the northern right of way, but these were later determined to be noncultural, most likely chert debris from local gravels brought in as road fill. Backhoe Trenches 12 and 13 were excavated in the southern right of way in the vicinity of this site. Artificial fill layers were exposed in the upper $15-30 \mathrm{~cm}$ of these trenches followed by ca. $30 \mathrm{~cm}$ of very dark gray clay with $40-80 \mathrm{~cm}$ of brown clay loam. The two trenches were excavated to ca. $150 \mathrm{~cm}$ in depth and exposed a brown clay loam in the lower portions of the trenches (see Appendix B). No prehistoric materials were observed. Because no cultural remains were found, no further work was conducted at this site, and no site revisit form was completed.

\section{MN12}

Site 41MN12 is located north of FM 2092 near the center of the project area and was originally recorded by Carlson (1991). This historic homesite and prehistoric artifact scatter also included a dense historic artifact scatter that she suggested dates from approximately 1850 to the present. Artifacts observed included various whitewares (1805-1900); aqua (1880-1916), brown, and lavender bottle glass (1880-1918); Albany-slipped stoneware (1900+); Bristolglazed stoneware (1920+); salt-glazed stoneware (pre-1900); cut nails; and building hardware (Carlson 1991:65-68). A 1907 Indianhead penny was collected from the site at that time. Cores, chert, and retouched flakes were also noted around the house. Shovel tests were shallow $(30-40 \mathrm{~cm})$ and recovered artifacts categorized as historic household and building materials and prehistoric lithics (Carlson 1991:65-68).

Current PAI investigations at $41 \mathrm{MN} 12$ included surface inspection within the right of way, photography of a lateral irrigation ditch, and an interview with a local informant. No historic artifacts were observed during extensive surface inspection in the right of way. Although Carlson's hand-drawn site location maps show the site boundary extending up to the FM 2092 roadway, a slight $30-\mathrm{cm}$ roadcut may have disturbed this portion of the site, or the artifact scatter may be limited to the house-barn conglomerate located ca. $100 \mathrm{~m}$ north of the roadway.

Jerry Rambo referred to this locale as the old Hinkle Dairy. In an interview, Rambo said, "This used to be a dairy at one time back in the '20s or the '30s-there was a dairy here. And Sammy Hinkle—he's still living-his folks had a dairy right there. And there was an old home there. And this lake down behind this home was fed by the ditch system there" (Jerry Rambo, personal communication 2006).

\section{MN13, Doug Matthews Grocery Store}

Site 41MN13, a historic farmstead and grocery store, is south of FM 2092 and is plotted south of the irrigation ditch on the USGS Chapman Draw quadrangle in the TARL map file. Carlson (1991:68-69) originally recorded the site in 1991, and a hand-drawn map found in the TARL files shows the site extending northward to FM 2092 and eastward to include an existing structure. This site was reported as a dense historic scatter in a field referred to by the owner as the "old homesite" where her grandfather had lived. However, the informant did not provide specific dates. At the time of the recording, visibility was 100 percent in the plowed field, and artifacts indicative of an earlytwentieth-century occupation were observed. Artifacts included blue Bristol-glazed stoneware (ca. 1880-1920), whiteware (1805-1900), lavender bottle glass (1880-1918), and assorted metal. Burned clay was observed to the south of the field, but the owner attributed the burned clay to bulldozing and burning of mesquite trees several years earlier (Carlson 1991:68-69).

Current investigations were limited to visual inspection of the right of way, the excavation of Auger Tests 28 and 29, and information from a local informant. Auger Tests 28 and 29 were placed at the eastern and western extent of the 41MN13 site boundaries on the south side of FM 2092. Auger Test 28 reached $83 \mathrm{~cm}$ and exposed pale brown silty loam with gravels throughout. No artifacts were recovered, but the remains of a home (a large concrete slab and tin outbuildings) was noted in a field to the 
south. Auger Test 29 reached $79 \mathrm{~cm}$ and exposed light grayish brown silty loam with gravels throughout. One piece of blue glass was recovered. A $30-\mathrm{cm}$ roadcut was noted adjacent to Auger Test 29.

Jerry Rambo noted a storm cellar, concrete slab, and cistern next to a small stone house immediately south of FM 2092. He stated:

Now see that old cellar there. There used to be an old grocery store there. And that was back in the wagon days.... There used to be a little grocery store there. Doug Matthews was the owner of it. And there's the old cistern right back of it and there's some of the cement slab that's still left to it... probably [would have been here] in the 1910s-'20s. Well, it was still there when I was a boy, uh, I'd say in the '30s [Jerry Rambo, personal communication 2006].

Site 41MN13 encompasses a large area with at least two historic components. The Matthews store is next to FM 2092 and a historic farmstead (with existing structures) located farther to the southwest. There is little chance that any significant historic deposits associated with the Matthews store remain intact within the FM 2092 right of way. Although no artifacts were observed within the right of way along this portion of FM 2092, a TexSite archeological site revisit form was filed at TARL describing the probable history of the site.

\section{MN15}

Site 41MN15 is located north of FM 2092 and was recorded in 1991. Carlson described the site as being on a knoll, with a prehistoric scatter as well as historic materials scattered around a brick house (1991:70-71). A sparse scatter of historic materials, mainly on the north edge of the knoll, included lavender bottle glass (18801918), whiteware, and metal debris. The prehistoric component consisted of a burned rock scatter with flakes, cores, and retouched flakes, but no formal tools. One piece of unglazed semiporcelain was collected at that time (Carlson 1991:70-71).
Current investigations included surface inspection and the excavation of Auger Tests 3037 and Shovel Tests 15-1-15-3 as well as limited interviews with the homeowners. Auger Tests 30-37 were placed $50-100 \mathrm{~m}$ apart from the western end of the previously recorded site boundary to ca. $200 \mathrm{~m}$ east of the eastern boundary. Auger Test 30 and 31 exposed $80 \mathrm{~cm}$ of fine brown silty loam with gravels in the upper $40 \mathrm{~cm}$. Auger Test 30 recovered one large possible tested cobble and one small corroded iron fragment. A few flakes and one fire-cracked rock were observed on the surface near the fence line at this location. Auger Test 31 recovered 11 flake fragments (probable road fill) and two thin metal fragments. Auger Test 32 exposed $114 \mathrm{~cm}$ of grayish brown clay loam with gravels in the upper $30 \mathrm{~cm}$ and recovered one small flake. Auger Test 33 exposed similar stratigraphy, but reached a depth of $79 \mathrm{~cm}$ and was negative. One possible flake fragment was recovered in Auger Test 34 that exposed $82 \mathrm{~cm}$ of brown silty clay loam with gravels throughout. Auger Tests 3537 were significantly more shallow, reaching $38 \mathrm{~cm}, 50 \mathrm{~cm}$, and $28 \mathrm{~cm}$ respectively and exposing grayish brown silty loam with gravels throughout. Auger Test 35 recovered 3 possible flakes; Auger Test 36 recovered 2 possible flakes, several fragments of thin rusted metal, and one fragment of turquoise glass (probable insulator glass); Auger Test 37 recovered 3 flakes (re-fits) that were most probably created by the auger.

Shovel Tests 15-1-15-3 were placed closer to the fence line in somewhat less disturbed context. Shovel Test 15-1 was placed $2 \mathrm{~m}$ west of Auger Test 37, near the eastern extent of the site. It exposed $50 \mathrm{~cm}$ of dark brown clay loam with no gravels and recovered 1 small bifacially flaked core in Level $2(20-40 \mathrm{~cm})$. Shovel Test 15-2 was placed $2 \mathrm{~m}$ east of Auger Test 36, exposed $40 \mathrm{~cm}$ of dark brown silty loam, and was negative. Shovel Test 15-3 was placed near the center of the site extent along FM 2092, ca. $5 \mathrm{~m}$ west of Kniffen Lane. The shovel test exposed $10 \mathrm{~cm}$ of dense gravels in brown silty loam and was negative.

The original site size was recorded as 30 square meters, but the hand-drawn map in the TARL site file shows the site spanning ca. $200 \mathrm{~m}$ east-west with ca. $80 \mathrm{~m}$ extending to FM 2092. Current investigations extend the site boundaries significantly, spanning $450 \mathrm{~m}$ east-west along FM 2092. A TexSite archeological site re- 
visit form was filed at TARL extending the site boundaries. The prehistoric and historic artifact scatters are very light within the right of way, and this area is highly disturbed. This portion of the site has very low research potential.

\section{MN20}

Site 41MN20 lies on a late Holocene alluvial terrace on the north side of FM 2092. Carlson recorded a historic scatter around several metal barns adjacent to the highway (1991:73-74). Artifacts observed included whiteware (1805-1900), Bristol-glazed stoneware (1920+), Albany-slipped stoneware (1900), lavender bottle glass (1880-1918), and cut nails. Numerous foundations, of relatively recent origin, were also noted. However, one foundation that appeared to be somewhat older, possibly turn-of-the-century, was observed in the grass east of the driveway (Carlson 1991:73-74).

PAI investigations included three auger tests and three shovel tests. Auger Tests 25-27 were placed ca. $100 \mathrm{~m}$ apart in the right of way adjoining the site boundaries. Auger Test 25 exposed $100 \mathrm{~cm}$ of pale brown silty loam and recovered one tested cobble and four fire-cracked rocks. Auger Test 26 exposed $90 \mathrm{~cm}$ of light brown sandy loam and recovered five flakes. And Auger Test 27 exposed $52 \mathrm{~cm}$ of brown silty loam with gravel in the upper $20 \mathrm{~cm}$ and recovered 10 flakes and one core.

Shovel Test 20-1 was placed $20 \mathrm{~m}$ south of a white wooden well house and $6 \mathrm{~m}$ south of a cluster of large oak trees. The shovel test exposed $50 \mathrm{~cm}$ of grayish brown gravelly silty loam and recovered three pieces of bottle glass in the upper $20 \mathrm{~cm}$, one piece of obsidian-like dark grayish black glass, and one piece of clear bottle glass. The lower $10 \mathrm{~cm}$ was negative. Shovel Test 20-2 exposed $10 \mathrm{~cm}$ of pale brown silt to silty loam and recovered 1 possible flake. Three possible flakes were observed on the surface near Shovel Test 20-3. This test exposed $40 \mathrm{~cm}$ of silty clay loam with dense small to medium-sized gravels and recovered four pieces of lightly patinated amber glass.

The site extent was originally recorded as 30 square meters. However, the hand-drawn map in the site file shows the site extending approximately $400 \mathrm{~m}$ along FM 2092. Current investigations recovered and observed artifacts in the right of way only along a ca. 100-m seg- ment north of the road. A barn appears at this location of the 1954 Texas Highway Department engineering schematic for FM 2092, but no evidence of this structure was observed during the current investigation. Although no artifacts were observed within the right of way along this portion of FM 2092, a TexSite archeological site revisit form was filed at TARL with revised site boundaries.

\section{MN21, Menard Irrigation Company System}

Carlson (1991:74-75) recorded the historic Menard Irrigation Company Canal as 41MN21 in 1991. This canal is the main channel of an extensive irrigation system that runs generally west to east in a meandering course through the San Saba River valley (see Figure 1). Over most of its course, the canal is less than $1 \mathrm{~km}$ south of and runs parallel to FM 2092. The canal runs within 20 m of FM 2092 midway in the project area, and the road crosses over the canal in the eastern end of the project area.

A more complete history of the Menard irrigation system was presented earlier in this report (see Chapter 3). The existing system dates to the 1870 s, but portions of the main canal were built following the much older Spanish colonial acequia (Doolittle 1995; Mark Wolf, personal communication 2006). Its nineteenth-century history is well known locally (Doolittle 1995). The Vaughan Agricultural and Mechanical Canal Company was chartered and construction on the canal began in 1874, and it extended for 5 miles to the east and west of Menard. Water began running two years later, and the irrigation was eventually expanded to cover more than 10 miles. "The Ditch," as it was later dubbed, irrigated approximately 2,000 acres and provided power to several gristmills in the San Saba River valley. The irrigation canal is still used today and is overseen by the Menard Irrigation Company. A Texas historical subject marker attests to the historical importance of this nineteenth-century irrigation system (Texas Historical Commission 1972).

Before beginning the archeological survey, PAI personnel used documents pertaining to the Menard Irrigation Company-such as copies of written company records in Mark Wolf's research files and various historic and modern aerial photos and maps-to plot the locations of 
irrigation system components. Locations where the main irrigation canal and lateral ditches crossed FM 2092 were put onto project area maps and aerial photos, which were then used by PAI personnel to guide the field survey.

Five crossings-one where FM 2092 crosses the main canal about $1.6 \mathrm{~km}$ west of Fivemile Crossing and four where it crosses smaller lateral ditches-were plotted. Each location was examined during the field survey. Black-andwhite and digital color photographs were taken to document the resources at each location. The only resources within the right of way were the concrete-lined culverts that go under the road. These almost certainly represent improvements that were installed during the 1950 s construction of FM 2092. Current construction plans for the improvements to FM 2092 state that the bridges and culverts will not be altered during this project (as specified in Work Authorization No. 57536SA006). Other substantial components of the irrigation system, such as concrete headgates, were observed near the road, but all of these areas were located outside the right of way and will not be impacted by the project.

\section{MN23, Mission San Sabá}

The location of Mission Santa Cruz de San Sabá was discovered by Kay Hindes, Mark Wolf, Kim Wolf, and Grant Hall in 1993. The current investigations concentrated on finding missionrelated cultural deposits within the FM 2092 right of way. During the testing phase, 19 gradall trenches, 11 test units, and 6 shovel tests were dug. During the data recovery phase, 78 1x1-m units, $41 \mathrm{x} 0.5-\mathrm{m}$ units, and two gradall-stripped blocks were placed. In total, 21 features were recorded. Two features are probable Spanish colonial posts, and one is a probable Native American bone deposit that dates to the Spanish occupation of the site. One is a small stain that is probably Spanish, one is a long but sporadic ash lens (a probable result of the mission massacre), two are small ash stains of unknown function or date, one is a small unassociated pit, three are tree root soil stains, and one is associated with fence disturbance. Also included are nine recent historic/modern (ca. 1954) fence posts or postholes.

Preliminary analysis of the artifacts collected resulted in $22.4 \mathrm{~kg}$ of daub and 94 Span- ish artifacts including majolica, olive jar, burnished redware and native-made ceramic sherds, container and flat glass, glass beads, wrought nails, melted lead pieces, snipe hinges, and chain links. Historic metal, glass, and ceramics were also collected. Ground stone and a hammerstone, melted objects, debitage, and lithic tools were collected but have not been classified with the Spanish or Native American occupations. Snail shells, mussel shells, charcoal, and bones were collected as well as wood and ash samples. Also observed were more than 1,000 modern artifacts, including fence staples, wire, scrap metal, nails, plastic, rubber, and glass.

After the survey investigations were completed, intensive data recovery investigations were undertaken at the mission site. The PAI survey and data recovery investigations are described in detail in a separate publication (McWilliams et al. 2007).

\section{NEWLY DISCOVERED SITES}

The PAI survey of the 4.7 miles along FM 2092 discovered and documented nine previously unrecorded sites within the TxDOT right of way. These sites were assigned temporary field numbers 2092-A through 2092-I during the survey, and shovel tests placed on each of the sites were numbered consecutively. Electronic site forms were submitted to the Texas Archeological Sites Atlas, and permanent trinomial numbers $41 \mathrm{MN} 53$ to $41 \mathrm{MN} 61$ were subsequently assigned to these sites. The following site descriptions include setting, description of current investigations, cultural materials observed, identification of site type, horizontal and vertical extent of cultural deposits, evaluation of impacts to cultural deposits within the TxDOT right of way, and evaluation of the site's research potential.

\section{MN53}

Site $41 \mathrm{MN} 53$ is on a Pleistocene-age terrace ca. 1-2 $\mathrm{m}$ above the Holocene floodplain of the San Saba River. A light prehistoric scatter was observed on the surface. The excavation of Backhoe Trench 4 confirmed that the cultural deposits were limited to the upper $20 \mathrm{~cm}$. The trench profile exhibited $28 \mathrm{~cm}$ of gravelly fill material over $1.0 \mathrm{~m}$ of light brown 
silty clay loam (see Appendix B). Observed artifacts included a few scattered burned rocks, widely scattered flakes (primarily tertiary and bifacial thinning flakes), mussel shells, including a few umbos, chert core, one chert unifacial tool fragment, and one middle-stage biface fragment. A few scattered early-twentiethcentury artifacts, including whiteware sherds, bottle glass fragments, clear window glass fragments, and a steel file handle, were observed.

Auger Test 47 was placed at the western end of the site and exposed $72 \mathrm{~cm}$ of pale brown silty loam. Four probable flake fragments were recovered in Auger Test 47. Both prehistoric and historic artifacts were primarily observed in the right of way on the south side of FM 2092. The site spans $80 \mathrm{~m}$ east-west by $25 \mathrm{~m}$ northsouth, based on observations within the existing right of way. All artifacts were in a surface context, which is disturbed. The portion of 41 MN53 within the FM 2092 right of way has a low research potential.

\section{MN54}

Site 41MN54 is on a slight rise immediately east of a small swale that is probably a fairly recent overflow chute of the San Saba River. Backhoe Trench 6 revealed fine-grained deposits in the swale, so the swale is not an old channel of the river. The artifacts observed included a few scattered burned rocks, widely scattered flakes including two secondary utilized flakes and tertiary flakes, a chert uniface fragment, a chert core, and mussel shell umbos and fragments. Bottle glass was also observed in the right of way. The site spans $30-40$ m east-west by ca. $25 \mathrm{~m}$ north-south within the existing right of way. Artifacts were more common in the right of way on the south side of FM 2092 but were present north of the highway as well. Material was concentrated in exposed areas. Some material may have been brought up to the surface when buried utility lines were dug. All artifacts were found in a surface context-possibly reaching a depth of $20 \mathrm{~cm}$ and in eroded area of the right of way, which is disturbed. No diagnostics were found, but the age of the deposit suggests that these materials are late-probably within the last 2,000 years. The portion of 41MN54 within the FM 2092 right of way has a low research potential.

\section{MN55}

Site 41MN55 is a Toyah phase artifact scatter on a Pleistocene-age terrace overlooking the San Saba River floodplain (Figure 8). The terrace surface, which is 4 to $5 \mathrm{~m}$ above the floodplain, is bisected by the road cut at the point where FM 2092 rises up from the floodplain. The terrace surface consists of grass-covered barrow ditches flanked by level fallow agricultural fields to the south and a small pecan orchard and homestead to the north. An occupied rock house is about 20 m north of the FM 2092 right of way near the edge of the terrace. The edge of the terrace and the active San Saba River floodplain are covered by pecan and elm trees. Prickly pear and mesquite grow along the edge of the right of way, particularly along the southern fence line. The age of the landform is interpreted as Pleistocene based on the stratigraphic profile of Backhoe Trench 11 (at the east end of the site), where a well-developed Bk or calcic horizon was observed. The calcic horizon was exposed from 102 to $125 \mathrm{~cm}$ in the trench, and it presumably extends deeper. It has more than 50 percent carbonate nodules toward the bottom of the trench, indicating that the alluvial deposit is ancient.

Scattered burned rocks, chert flakes (primary, tertiary, and bifacial thinning flakes), two utilized flake tools, two blade flakes, one possible limestone mano, three bone-tempered pottery sherds, and mussel shell umbos and fragments were observed. Artifacts were primarily observed in the right of way on the north side of FM 2092 but were also present on the south. All artifacts were observed where the road cuts down into the margin of the Pleistocene terrace. Material appeared to be eroding down the exposed road cut face, but fewer materials were observed east of the terrace margin on the intact terrace surface on both the north and south sides of FM 2092. The site is $190 \mathrm{~m}$ eastwest by $25 \mathrm{~m}$ north-south.

Subsequent to the survey, National Register testing was conducted at this site. The results of that investigation are reported in a separate publication (McWilliams et al. 2007).

\section{$41 \mathrm{MN56}$}

Site 41MN56, located on a Late Holocene alluvial terrace, consists of a few scattered 
Plan

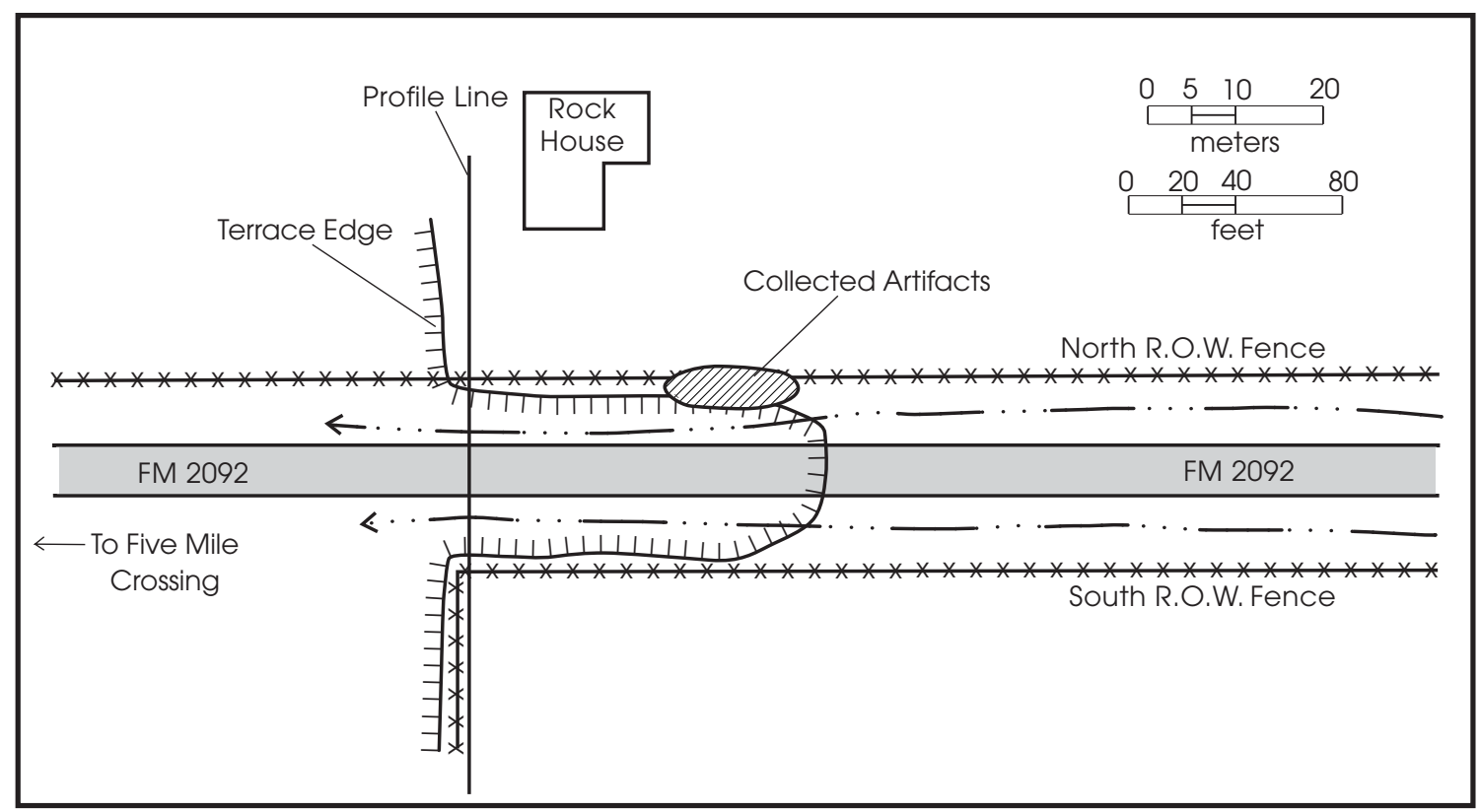

Profile

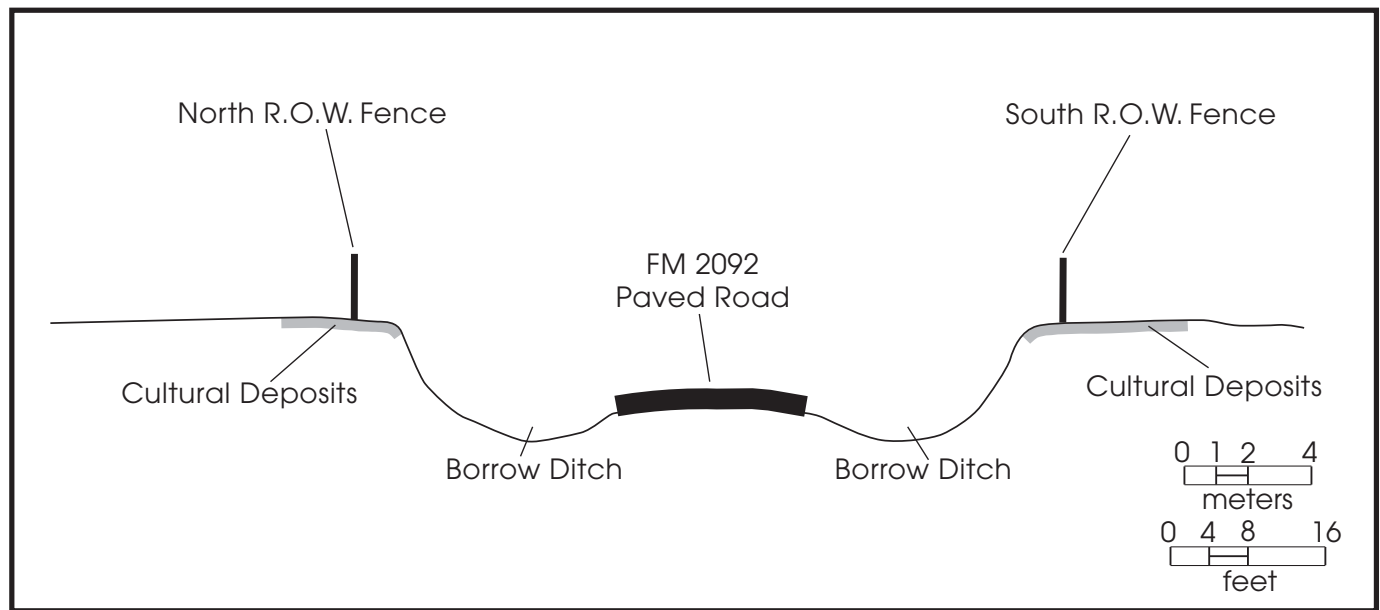

PAI/06/BW

Figure 8. Plan and profile of 41MN55, a probable Toyah phase occupation site on a Pleistocene terrace overlooking the San Saba River floodplain at Fivemile Crossing. 
burned rocks, widely scattered flakes, and mussel shells. The site was revealed in auger tests and shovel tests placed the northern FM 2092 right of way. Auger Tests 1-4 exposed 72-100 cm of road fill over pale brown to pinkish brown clay to silty clay loam. Auger Test 1 recovered 2 flakes, and Auger Tests 2-4 recovered 1 flake each. A biface was found near the northern rightof-way fence line at Auger Test 3. Shovel Tests were placed between the positive auger tests to establish depth of the deposit. Shovel Tests 561 through 56-5 were negative. Shovel Test 56-6 yielded three flakes (one primary, one secondary, and one possible) and three mussel shell fragments from Level $2(20-40 \mathrm{~cm})$. Level $3(40$ $60 \mathrm{~cm}$ ) produced one mussel shell fragment.

Artifacts were primarily observed in the right of way on the south side of FM 2092 and were primarily in a surface context, which is disturbed. A ca. 40-cm-deep road cut runs along the northern side of FM 2092 at this location. No cultural materials were observed on the south side of FM 2092, which lies on a lower plain. The site extent spans $160 \mathrm{~m}$ east-west by $2 \mathrm{~m}$ north-south (due to the roadcut). The portion of 41MN56 within the FM 2092 right of way has a low research potential.

\section{MN57}

Site 41MN57, which lies on a Late Holocene alluvial terrace, consists of two areas of widely scattered flakes and one core observed on the surface. The site was revealed in auger tests and shovel tests placed in a disturbed setting within the existing FM 2092 right of way. Auger Tests 13 and 14 both exposed $104 \mathrm{~cm}$ of pale brown silty loam with gravels throughout. Auger Test 13 recovered three flakes, one mussel shell umbo, two mussel shell fragments, and one whiteware sherd. Auger Test 14 recovered two flakes. Four shovel tests were placed between the auger tests to determine the depth of the deposit. Shovel Tests 57-1, 57-3, and 57-4 were negative. Shovel Test 57-2 recovered one core (unifacially flaked), one piece of weathered bone, and three pieces of modern bottle glass in Level $1(0-20 \mathrm{~cm})$.

Auger tests were positive, necessitating shovel tests, which revealed only a light surface scatter of prehistoric artifacts, one whiteware sherd, a bone fragment (which could be modern, historic, or prehistoric), and modern mate- rial. Artifacts were observed in the right of way on the north side of FM 2092. Within the right of way, the site spans $140 \mathrm{~m}$ east-west by $5 \mathrm{~m}$ north-south. All artifacts are in a surface context, which is disturbed. The portion of 41MN57 within the FM 2092 right of way has a low research potential.

\section{MN58}

Site 41MN58 lies on a Late Holocene alluvial terrace and was revealed in one auger test, four shovel tests placed in a disturbed setting within the existing FM 2092 right of way, and surface scatter. Auger Test 9 exposed $103 \mathrm{~cm}$ of pale brown silty sandy loam and recovered two large flakes, one fire-cracked rock, and four mussel shell fragments. Four shovel tests were placed around the positive auger test to determine site extent and depth of the deposit. Shovel Tests 58-1-58-3 exposed 10-20 cm of gravels over a compact caliche layer (possibly road base). Shovel Test 58-1 recovered one flake, Shovel Test 58-2 recovered one piece of fire-cracked chert, and Shovel Test 58-3 recovered one piece of firecracked chert and one piece of fire-cracked rock. Shovel Test $58-4(0-40 \mathrm{~cm})$ exposed $20 \mathrm{~cm}$ of similar upper deposits but extended to $40 \mathrm{~cm}$, becoming compact. Shovel Test 58-4 recovered one flake in Level $1(0-20 \mathrm{~cm})$ and one piece of thin black glass in Level $2(20-40 \mathrm{~cm})$. Several scattered burned rocks were also observed on the surface.

Site $41 \mathrm{MN} 58$ spans $170 \mathrm{~m}$ east-west by $5 \mathrm{~m}$ north-south as seen in auger and shovel tests as well as surface scatter. Artifacts were only observed in the right of way on the north side of FM 2092, in a disturbed surface context. The portion of 41MN58 within the FM 2092 right of way has a low research potential.

\section{MN59}

Site 41MN59 lies on a Late Holocene alluvial terrace. The site was revealed in auger tests placed in a disturbed setting within the existing FM 2092 right of way as well as a surface scatter. Auger Test 49 exposed $84 \mathrm{~cm}$ of brown silty loam with gravels and recovered eight mussel shell umbos and mussel shell fragments. Auger Test 50 reached $79 \mathrm{~cm}$ and exposed a similar profile. Auger Test 50 recovered three flakes, two mussel shell umbos, and mussel shell frag- 
ments. Five fire-cracked rocks, one core, and mussel shell fragments were also observed on the surface.

Site 41MN59 consists of a few scattered burned rocks, very widely scattered flakes, and mussel shells. Three flakes and one fire-cracked rock were found in the right of way near Auger Test 49. Three additional flakes, one core, and four fire-cracked rocks were found scattered between Auger Test 49 and Auger Test 50 and to the east. Artifacts were only observed in the right of way on the north side of FM 2092. The site spans $170 \mathrm{~m}$ east-west by $5 \mathrm{~m}$ north-south on the north side of FM 2092 only. All artifacts are in a surface context, which is extensively disturbed within the right of way. It appears that artifacts extend into the plowed field to the north. The portion of 41MN59 within the FM 2092 right of way has a low research potential.

\section{MN60}

Site 41MN60, which lies on a Late Holocene alluvial terrace, is a historic farmstead with a light prehistoric scatter. The site was revealed in auger tests and shovel tests placed in a disturbed setting within the existing FM 2092 right of way. Auger Tests 18-20 were placed to the east and west of an extant wooden windmill stand overlying a brick well and an extensive surface scatter of cinder blocks, bricks, and historic debris outside the right of way. Auger Tests 18-20 exposed 80-95 cm of grayish brown silty loam, with gravels in the upper $30 \mathrm{~cm}$. Auger Test 19 recovered 6 possible flakes, charcoal, eight pieces of corroded iron, one lightly patinated clear class, one aqua mold-formed glass fragment, and one small animal long bone with spiral fracture. Auger Test 19 exposed six probable flakes and a probable twentiethcentury iron wire fence staple. Auger Test 20 recovered several fragments of corroded iron (probable twentieth-century artifacts).

Three shovel tests were placed in between and west of the auger tests. Shovel Tests 60-160-3 exposed 50-80 cm of moist brown silty loam. Shovel Test $60-1$ produced one milk glass bottle rim, one washer, three corroded metal scraps, one tin can piece, one cut long bone fragment, one piece of wire, one clear glass from Level 1 (0$20 \mathrm{~cm}$ ); one flake, eight corroded metal scraps, two pieces of wire, two clear glass fragments, and a small animal vertebra from Level $2(20-40 \mathrm{~cm})$; eight corroded metal scraps, two bone fragments, and one piece of wire from Level $3(40-60 \mathrm{~cm})$; and three pieces of wire and two corroded metal scraps from Level $4(60-80 \mathrm{~cm})$.

Shovel Tests $60-2$ exposed more than 20 pieces of clear thin bottle glass, one aqua glass fragment, two sherds of a decorative transferware teacup from Level $1(0-20 \mathrm{~cm})$, and one transferware sherd (same as above), one cut nail, three metal can rim fragments, one fragment of patinated clear glass, one burned cut bone fragment, and charcoal from Level 2 (20$40 \mathrm{~cm})$. Levels $3(40-60 \mathrm{~cm})$ and $4(60-80 \mathrm{~cm})$ were negative. Finally, Shovel Test $60-3$ recovered a .22-caliber cartridge case, one corroded piece of scrap metal, one undecorated whiteware sherd, patinated bottle glass (two oxidized, one aqua, two clear), one metal bottle cap, and foil from Level 1 $(0-20 \mathrm{~cm})$; and one fence staple, three corroded pieces of metal, one large whiteware sherd, and one gold-painted whiteware sherd from Level $2(20-40 \mathrm{~cm})$. Level $3(40-50 \mathrm{~cm})$ was negative.

Site $41 \mathrm{MN} 60$ extends $120 \mathrm{~m}$ east-west by $2 \mathrm{~m}$ north-south, truncated by a roadcut. A house appears in this location-close to the old roadon the 1954 Texas Highway Department engineering schematic for FM 2092. The house may have been moved or burned during the 1954 roadwork or possibly at a later date. The historic archeological remains within the FM 2092 right of way have a low research potential.

\section{MN61}

Site 41MN61, which lies on a Late Holocene alluvial terrace, is the northern extent of a homesite. The site was observed as extending out from yards of two homes: A large nineteenth-century wooden two-story house ca $30 \mathrm{~m}$ south of the right of way and a small 1920s-'30s stone cottage ca. $15 \mathrm{~m}$ south of the right of way. The site was revealed in auger tests and shovel tests placed in a disturbed setting within the existing FM 2092 right of way. Auger Test 21 recovered two flakes. Auger Test 22 recovered an old metal can and one small fragment of rusted iron, and Auger Test 23 recovered two flakes. Shovel Tests 61-1-61-3 were placed between the auger tests. Shovel Test 61-3 was the only positive shovel test, with one flake found in Level 1 $(0-10 \mathrm{~cm})$. No cultural material was observed on the surface.

Jerry Rambo referred to the large wooden 
home as the Buierer (Buier) Home. The site extends 110 m east-west and spans only $5 \mathrm{~m}$ northsouth along the southern right of way. The historic archeological remains of $41 \mathrm{MN} 61$ that are within the FM 2092 right of way have a low research potential.

\section{HISTORIC LOCALITIES IDENTIFIED IN ARCHIVAL RECORDS OR BY INFORMANTS}

Seventeen historic localities were identified next to FM 2092 through archival research and oral history interviews. Although the road sections closest to each of these locations were closely examined, no cultural materials or other physical evidence associated with any of these localities were found within the road right of way. Consequently, these localities were not recorded as archeological sites, but they include the following types of resources: irrigation laterals and other old ditches; historic graves; historic road bridges; homesites; the location of the original Mission San Sabá historical monument; sections of wagon roads, a Texas Rangers' camp, and the general location of a possible Spanish colonial-age smelter. Figure 9 shows the locations of these historic localities and ditch segments plotted on the modern aerial photograph.

\section{Ditch Crossings 1-5}

Four crossings of irrigation laterals and the main canal were photographed between the Menard city limits and Fivemile Crossing (see Figure 9). These were assigned Ditch Crossing numbers 1-5 moving west to east through the project area. The four laterals are limited to concrete ditches within the right of way, but water "gates" are present at some locations immediately beyond the right of way. Technically, these laterals should be part of $41 \mathrm{MN} 21$, which Carlson (1991) originally recorded to designate the main irrigation canal, which is Ditch Crossing 5 (see 41MN21 earlier in this chapter). These laterals are discussed in Chapter 3 as components of the irrigation system administered by the Menard Irrigation Company.

\section{Historic Localities 1-4}

Historic localities 1-4 are historic graves located north of FM 2092 and outside the state right of way. A tombstone enclosed in a wroughtiron fence can be seen about 20 yards north of FM 2092, about 1 mile east of Menard and $40 \mathrm{ft}$ north of the highway. Protected in an oak tree motte, the tombstone marks the grave of Tull B. Smith (also written Tullos B. Smith and Tully V. Smith). Information on the graves was collected from the Internet, the Menard County History and Anthology, an interview with local informant, Jerry Rambo, and e-mails from Alicia Brown, a local volunteer with the TXGenWeb Project.

Tully B. Smith is listed as a country storekeeper, age 37, in the 1870 Menard Census. He is listed along with his presumed wife, Cynthia E. Smith, and children Lucilla A. (9), Brooklin (5), Robert S. (2), and Abijah/Alijah (4 mo.), as well as Saul Smith (70) and John M. Fuller (27), a salesman in the store (Brown 2006). Brown states that Tully was born January 14, 1833, and died January 10, 1871. East of his headstone is a concrete slab. Two more concrete slabs are east of the iron fence. Jerry Rambo stated that one additional tombstone was present in the 1940 s, when his uncle and aunt owned the land. The second headstone and parts of the fence were stolen over the years.

This is where your river makes a bend and goes north there. We're right on that curve in the road. And right straight in front of us where those live oaks are is where your graves are...on the north side of the road...My uncle and aunt owned the property at one time. And they didn't want those graves disturbed but people were taking the steel fences and one of the steel fences is still around the marker....See there's a stone there, well there were two of those when my aunt and uncle owned the property [Jerry Rambo, personal communication 2006].

Alicia Brown, a local genealogist, has collected information about Tull Smith from articles, conversations, and records but cannot confirm their accuracy. She has learned that Smith's wife may have been Cynthia B. Russell, 


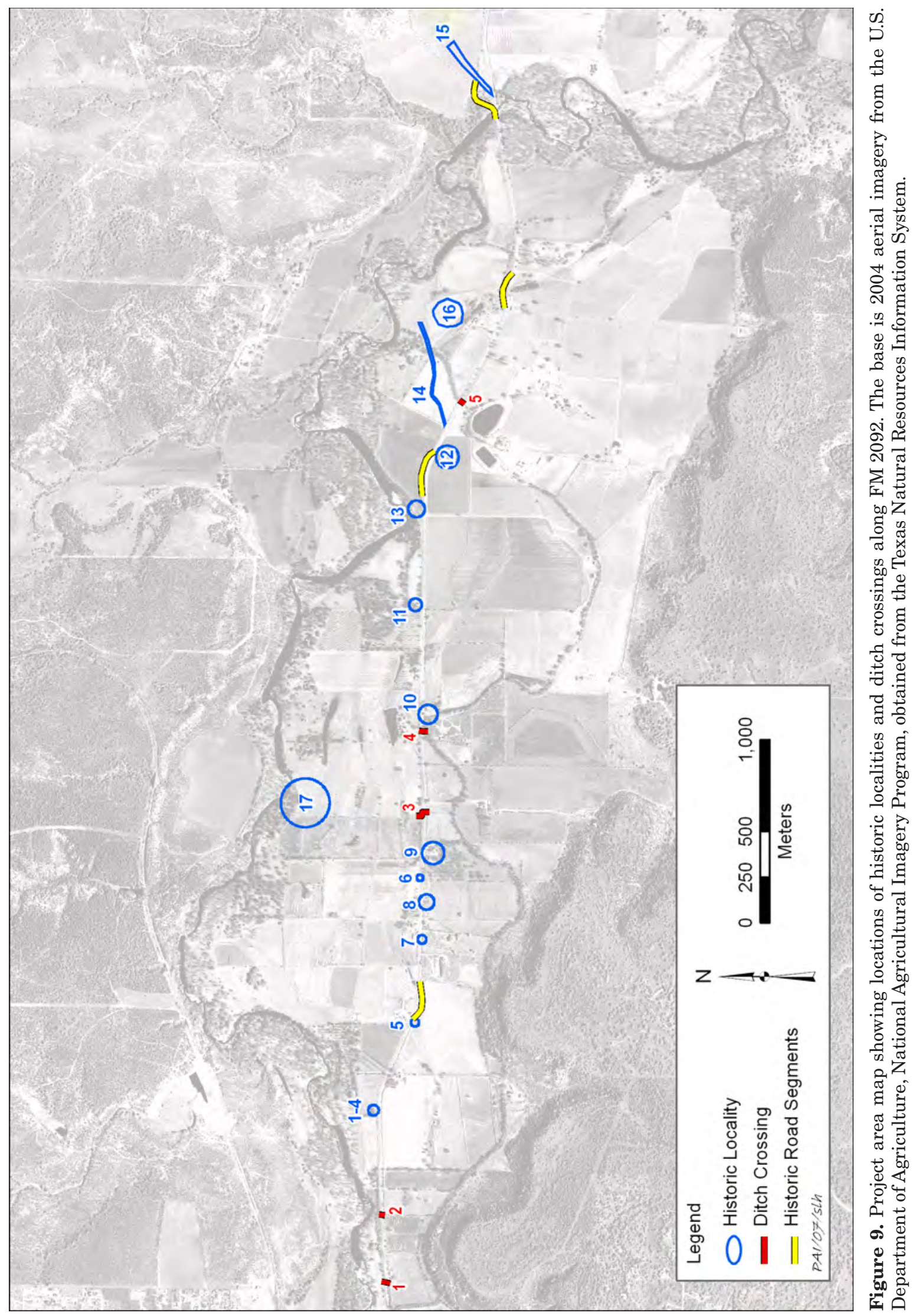


and there is a possibility that her burial may be next to Smith's and was marked by the second (missing) headstone.

According to local lore, Tull was on his way home one day when Indians attacked him. However, it appeared that "he had been shot with a gun and an arrow was placed in the wound to make it look like an Indian had done it" (Brown 2006). The West Texas Frontier by Joseph Carroll McConnell (McConnell 1933) provides another version of the story:

Tullos B. Smith was returning late in the evening to his home in Menard, from the Wilkerson Ranch, about sixteen miles away, was mounted on a large black pony, and was leading about two other horses. As he passed a cluster of bushes, a few miles from his destination, Tullos B. Smith was ambushed and killed. Late in the evening the stage going from San Antonio to El Paso came along and found him. Since he was not scalped, some local citizens thought perhaps he may not have been killed by Indians. Searching parties soon found moccasin tracks, however, and other Indian signs. Wm. Templeton, Lewis Wilson and David Thorp brought Tullos B. Smith's body to Menard in a spring wagon. Note: Author interviewed: J. F. P. Kruse, who intended to accompany Tullos B. Smith to the Wilkerson Ranch but was unable to find his pony; Mr. and Mrs. Ben Ellis and Mr. and Mrs. J. D. Carlisle, who were early settlers in that section [McConnell 1933].

It is also reported that J. P. Kruse married Tull's widow, Cynthia (Brown 2006).

Other references state that three children of the Bradford family are buried here. Brown quotes an excerpt from the Menard News Centennial Edition (dated November 11, 1971): "Adam Bradford reared seventeen children to be adults...two or three small children of his are buried east of Menard in what is now a field. The small tombstones can still be seen under some live oak trees" (Brown 2006). One publication claims that a young woman who had been scalped and later died was buried one-half mile east of Menard, suggesting yet another burial in the vicinity (Menard County Historical Society 1982).

One lady told of some travelers who came to Menard, bringing with them a woman of undetermined age who had been scalped. They had found her lying on the bank of Scalp Creek, but she died shortly thereafter. Another man said this brother-in-law told him that the woman scalped by the Indians was a sixteen year old white girl who had red hair. He thinks she is buried about one half mile east of Menard on the Five Mile Road [Menard County Historical Society 1982].

The burials were assigned historic localities 1-4, representing (1) the marked grave of Tull Smith; (2) possible unmarked grave (headstone reportedly stolen) next to Smith; (3) possible unmarked grave(s) of the Bradford children; and (4) possible unmarked grave of the scalped woman. No archaeological site forms were completed because the graves are located on private property and could not be examined.

This information suggests that additional graves may be located beyond the iron fence and could extend into the FM 2092 right of way. PAI personnel conducted gradall scraping at this location, but no addition graves were found. More information on this investigation is found in the summary of gradall trenching in Chapter 4 .

\section{Historic Locality 5}

A historic concrete bridge lies ca. $10 \mathrm{~m}$ south of the southern right of way, ca. 1.6 miles east of Menard. The bridge crosses Harris Hollow and is designated as historic locality 5 . The bridge is located by a large pecan tree and consists of a 
little concrete archway with minimal rockwork on the edges. Jerry Rambo stated that this bridge was located along the original route of FM 2092 but was avoided during the 1954 paving, when a curve was straightened.

In an interview, he said, "OK, now this curve here has been changed. I can show you the old wagon or gravel road that was traveled when it was gravel because they had a bridge over at that time-over Harris Hollow to the south side of the road..." (Jerry Rambo, personal communication 2006). He recalled that he traveled over the bridge when he was young.

No sign of the roadway was observed in the right of way; construction and maintenance of FM 2092 may have obliterated the original road.

\section{Historic Locality 6}

Historic locality 6, the location of the original historic marker for the Mission San Sabá, is ca. 2 miles east of Menard. The marker was placed south of a large motte of oak trees in what was once thought to be the original mission location. Many locals stated that they believed the mission was at that location for so many years because that is where the marker was placed in 1936. Carlson recorded a prehistoric lithic scatter and historic farmstead in the oak motte in 1991. Historic artifacts from 41MN22 are suggestive of a turn-of-the-century domestic site (Carlson 1991).

\section{Historic Locality 7}

Historic locality 7 is a whitewashed stone well house that is immediately south of the right of way, ca. 1.7 miles east of Menard. Three auger tests were placed northeast, north, and northwest of the well house, below a ca. $1 \mathrm{~m}$ roadcut. The tests, placed in a disturbed setting due to the roadcut, were negative. Several large rocks extend into the right of way within the roadcut and could be part of base of the well house. Jerry Rambo said that the well house was made of hand-hewn limestone that was plastered and painted white (Jerry Rambo, personal communication 2006).

\section{Historic Localities 8-10}

Historic localities 8, 9, and 10 are historic homesites or businesses that are now consid- ered part of recorded archeological sites. Based on artifacts found at these localities, they are now linked with historic archeological sites $41 \mathrm{MN} 60,41 \mathrm{MN} 61$, and 41MN13, respectively, and are described above.

\section{Historic Locality 11}

Historic locality 11 is a slight swale running north-south across the FM 2092 right of way, just west of Monte and Suzie Lyckman's house. It is all that remains of an irrigation lateral at the far western end of the Mission San Sabá site (41MN23). This ditch once had a metal flume that carried water over Harris Hollow, about $100 \mathrm{~m}$ north of FM 2092. The ditch has been abandoned, and the flume has been gone for many years (Jerry Rambo, personal communication 2006; Monte Lyckman, personal communication 2006).

\section{Historic Locality 12}

In his 1901 map, J. J. Callan indicated a place close to Mission San Sabá that he labeled "Presidio. Smelter." It is not clear what this represents. Because of its location, it is possible that Callan interpreted the mission remains as those of a smelter, but this interpretation is speculative.

\section{Historic Locality 13}

A historic wagon road to the river was used in the 1910-1930s. It is assigned historic locality 13 . The road was located just east of the mission, where the river dips southward. Before the 1940 s, the river ran farther north, and a huge spring flowed at this location. It was a popular swimming hole and picnic location in the 1910 s1930 s, according to Jerry Rambo (personal communication 2006).

\section{Historic Locality 14}

A linear depression can be seen extending across a field east of the mission. Mark Wolf observed this north-northeasterly line in an aerial photo and considers it to be a possible old wagon road. The linear feature is probably an old road. It runs through 41MN5, a historic site recorded in a 1990 survey by Texas A\&M University (see description earlier in this chapter [Carlson 1991]). Additional research suggests 
that both 41MN5 and this linear feature are remains of a historic settlement called Sunnyside (Smyrl 2001). The settlement was established for workers of the Gus Noyes farm and perhaps was occupied by workers who helped expand the irrigation ditch. Sunnyside, located 3 miles east of Menard and 1 mile west of the Noyes farm, was apparently present in the 1880s but does not appear on 1940s county maps. The community consisted of a cotton gin, a store, and a school, although homes or a tent camp were probably also present. Jerry Rambo reported that his father attended school at this location (Jerry Rambo, personal communication 2006). Carlson (1991) recorded a gin and a historic scatter as 41MN5, and the field is referred to as the McDaniels' place.

\section{Historic Locality 15}

A probable old wagon road is recorded as historic locality 15 based on information from local informant Jerry Rambo (personal communication 2006). The old road turned northward off of FM 2092 at the far eastern end of the project area, and it is reported to have predated the existing paved highway. A modern road called Vinegaroon Road runs at a northeasterly direction of FM 2092 at this general location and may follow the old wagon road.

\section{Historic Locality 16}

Historic locality 16 is a concrete bridge over an unnamed drainage, which is really little more than a swale. The bridge was once on the county road, but it has been abandoned since the 1954 construction of FM 2092. The 1954 aerial photograph shows that this bridge was near a bend in the country road, and that it was cut off when FM 2092 was built. The bridge location is now about $30 \mathrm{~m}$ to $40 \mathrm{~m}$ north of FM 2092, just northeast of 41MN53. A linear concentration of gravels, easily visible from FM 2092, marks the location of the old county road in this area.

\section{Historic Locality 17}

Historic locality 17, the possible location of a Texas Rangers' camp and tent camp of Captain Dan Roberts, is ca. $0.8 \mathrm{~km}$ north of FM 2092, ca. 2 miles east of Menard. The camp was described in a publication containing the memoirs of Captain Dan Roberts and those of his wife (Roberts and Roberts 1987). The camp was reportedly 2 miles east of Menard, but the home of Captain Roberts and his wife was 1.5 miles east of Menard, possibly set away from the camp for privacy. The camp was in this vicinity from 1875 to 1878. 



\title{
NATIONAL REGISTER ASSESSMENTS, EVALUATION OF PROJECT-RELATED IMPACTS, AND MANAGEMENT RECOMMENDATIONS
}

\author{
Douglas K. Boyd and Jennifer K. McWilliams
}

6

The intensive archeological survey resulted in documentation of 19 archeological sites that are adjacent to or within the FM 2092 right of way owned by the State of Texas (see Table 5). Four are previously recorded sites that are adjacent to the road and presumably have remains that extend (or once extended) into the roadway, but no archeological remains were observed within the right of way. Six are previously recorded sites where remains were found inside the right of way. Nine are newly discovered sites. Of these 19 sites, 6 have prehistoric components, 4 have historic components, and 9 have both prehistoric and historic components.

\section{PRELIMINARY SURVEY REPORT AND PROJECT REVIEW BY TxDOT AND THC}

All of the sites documented along FM 2092 were described in a preliminary report submitted to TxDOT-ENV (Boyd et al. 2006). The preliminary report was reviewed by TxDOT-ENV and THC, and they concurred with all of the recommendations that were made. Table 6 summarizes the assessments and recommendations for the 19 sites adjacent to or within the FM 2092 right of way. The archeological sites were evaluated for potential to be listed on the National Register of Historic Places (National Register) under Criterion D, according to Section 106 of the National Historic Preservation Act (16 USC 470 et seq.; 36 CFR 800), and for potential for designation as a State Archeological Landmark (SAL), according to the Antiquities Code of Texas (Texas Natural Resources Code, Title 9, Chapter 191; 13 TAC 26).

For the purpose of discussing site assessments and recommendations, these sites are grouped as prehistoric and historic sites. Two sites-the Menard Irrigation Company system and Mission San Sabá-are discussed separately. Seventeen historic localities, for which historical evidence was examined, also are discussed. The remainder of this report presents the assessments and recommendations for these resources (see Boyd et al. 2006).

\section{PREHISTORIC SITES}

Fifteen sites adjacent to or within the FM 2092 right of way have prehistoric components (see Tables 3 and 5). At four previously recorded sites, PAI found no evidence that cultural remains actually extended into the right of way, and these sites (41MN5, 41MN9, $41 \mathrm{MN} 11$, and $41 \mathrm{MN} 12$ ) were recommended as not eligible for listing in the National Register or for designation as SALs. Prehistoric remains found within the right of way at two sites represent low-density ephemeral occupations in disturbed contexts. The prehistoric components at these sites, $41 \mathrm{MN} 15$ and $41 \mathrm{MN} 23$, were recommended as not eligible for listing on the National Register or for designation as SALs.

Prehistoric components were present in the TxDOT right of way at all nine of the newly recorded sites. All of these components are low-density artifact scatters where no buried occupation zones or cultural features were identified. At eight of these sites, the prehistoric remains within the right of way appear to be in extensively disturbed contexts due to previous agricultural activities (i.e., plowing) and later FM 2092 construction. The prehistoric components at each of these eight sites (41MN53, 41MN54, and 41MN56-61) were recommended as not eligible for listing in the National Register or for designation as SALs. 
Table 6. Assessments and recommendations for portions of archeological sties within the FM 2092 right of way*

\begin{tabular}{|c|c|c|c|c|}
\hline $\begin{array}{l}\text { Site } \\
\text { Number }\end{array}$ & Component & Description & Assessment* & Recommendation \\
\hline \multicolumn{5}{|c|}{ Previously Recorded Sites } \\
\hline $41 \mathrm{MN} 5$ & $\begin{array}{l}\text { Historic } \\
\text { Prehistoric }\end{array}$ & $\begin{array}{l}\text { Former townsite of Sunnyside } \\
\text { Lithic scatter }\end{array}$ & $\begin{array}{l}\text { Not eligible } \\
\text { Not eligible }\end{array}$ & $\begin{array}{l}\text { No further work } \\
\text { No further work }\end{array}$ \\
\hline $41 \mathrm{MN} 9$ & $\begin{array}{l}\text { Historic } \\
\text { Prehistoric }\end{array}$ & $\begin{array}{l}\text { Farmstead } \\
\text { Lithic scatter }\end{array}$ & $\begin{array}{l}\text { Not eligible } \\
\text { Not eligible }\end{array}$ & $\begin{array}{l}\text { No further work } \\
\text { No further work }\end{array}$ \\
\hline $41 \mathrm{MN} 10$ & Historic & $\begin{array}{l}\text { Historic farmstead (turn-of-the- } \\
\text { century) }\end{array}$ & Not eligible & No further work \\
\hline $41 \mathrm{MN} 11$ & Prehistoric & $\begin{array}{l}\text { Prehistoric burned rock and lithic } \\
\text { scatter }\end{array}$ & Not eligible & No further work \\
\hline $41 \mathrm{MN} 12$ & $\begin{array}{l}\text { Historic } \\
\text { Prehistoric }\end{array}$ & $\begin{array}{l}\text { Farmstead } \\
\text { Lithic scatter }\end{array}$ & $\begin{array}{l}\text { Not eligible } \\
\text { Not eligible }\end{array}$ & $\begin{array}{l}\text { No further work } \\
\text { No further work }\end{array}$ \\
\hline $41 \mathrm{MN} 13$ & Historic & $\begin{array}{l}\text { Historic farmstead and store } \\
\text { (early 20th century) }\end{array}$ & Not eligible & No further work \\
\hline $41 \mathrm{MN} 15$ & $\begin{array}{l}\text { Historic } \\
\text { Prehistoric }\end{array}$ & $\begin{array}{l}\text { Artifact scatter } \\
\text { Burned rock scatter with lithics }\end{array}$ & $\begin{array}{l}\text { Not eligible } \\
\text { Not eligible }\end{array}$ & $\begin{array}{l}\text { No further work } \\
\text { No further work }\end{array}$ \\
\hline $41 \mathrm{MN} 20$ & Historic & $\begin{array}{l}\text { Historic farmstead (turn-of-the- } \\
\text { century) }\end{array}$ & Not eligible & No further work \\
\hline $41 \mathrm{MN} 21$ & Historic & $\begin{array}{l}\text { Menard Irrigation Company } \\
\text { irrigation system (1874 to } \\
\text { present) }\end{array}$ & $\begin{array}{c}\text { Potentially } \\
\text { eligible** }\end{array}$ & No further work \\
\hline $41 \mathrm{MN} 23$ & \begin{tabular}{|l} 
Historic \\
(Spanish \\
Colonial) \\
Prehistoric \\
\end{tabular} & $\begin{array}{l}\text { Spanish Mission: Santa Cruz de } \\
\text { San Sabá (1757-1758) } \\
\text { Lithic scatter }\end{array}$ & Not eligible & $\begin{array}{l}\text { Data recovery of } \\
\text { Spanish colonial } \\
\text { remains in the FM } \\
2092 \text { right of way } \\
\text { No further work } \\
\end{array}$ \\
\hline \multicolumn{5}{|c|}{ Newly Recorded Sites } \\
\hline $41 \mathrm{MN} 53$ & $\begin{array}{l}\text { Historic } \\
\text { Prehistoric }\end{array}$ & $\begin{array}{l}\text { Possible farmstead } \\
\text { Lithic scatter }\end{array}$ & $\begin{array}{l}\text { Not eligible } \\
\text { Not eligible }\end{array}$ & $\begin{array}{l}\text { No further work } \\
\text { No further work }\end{array}$ \\
\hline $41 \mathrm{MN} 54$ & $\begin{array}{l}\text { Historic } \\
\text { Prehistoric }\end{array}$ & $\begin{array}{l}\text { Artifact scatter } \\
\text { Lithic scatter }\end{array}$ & $\begin{array}{l}\text { Not eligible } \\
\text { Not eligible }\end{array}$ & $\begin{array}{l}\text { No further work } \\
\text { No further work }\end{array}$ \\
\hline $41 \mathrm{MN} 55$ & Prehistoric & $\begin{array}{l}\text { Shallowly buried campsite; } \\
\text { probable Toyah phase occupation }\end{array}$ & $\begin{array}{l}\text { Potentially } \\
\text { eligible }\end{array}$ & $\begin{array}{l}\text { Testing of deposits } \\
\text { in the FM } 2092 \\
\text { right of way to } \\
\text { determine } \\
\text { National Register } \\
\text { eligibility } \\
\end{array}$ \\
\hline $41 \mathrm{MN} 56$ & Prehistoric & Prehistoric lithic scatter & Not eligible & No further work \\
\hline 41MN57 & Prehistoric & Prehistoric lithic scatter & Not eligible & No further work \\
\hline $41 \mathrm{MN} 58$ & Prehistoric & Prehistoric lithic scatter & Not eligible & No further work \\
\hline $41 \mathrm{MN} 59$ & Prehistoric & Prehistoric lithic scatter & Not eligible & No further work \\
\hline $41 \mathrm{MN} 60$ & $\begin{array}{l}\text { Historic } \\
\text { Prehistoric }\end{array}$ & $\begin{array}{l}\text { Farmstead } \\
\text { Lithic scatter }\end{array}$ & $\begin{array}{l}\text { Not eligible } \\
\text { Not eligible }\end{array}$ & $\begin{array}{l}\text { No further work } \\
\text { No further work }\end{array}$ \\
\hline $41 \mathrm{MN} 61$ & $\begin{array}{l}\text { Historic } \\
\text { Prehistoric }\end{array}$ & $\begin{array}{l}\text { Homesites } \\
\text { Lithic scatter }\end{array}$ & $\begin{array}{l}\text { Not eligible } \\
\text { Not eligible }\end{array}$ & $\begin{array}{l}\text { No further work } \\
\text { No further work }\end{array}$ \\
\hline
\end{tabular}

* Except as noted, assessment refers to the portion of the site within the TxDOT right of way and its eligibility for listing on the National Register of Historic Places under Criterion D (archeological research potential) and for designation as a State Archeological Landmark. These recommendations were presented previously in the preliminary survey report by Boyd et al. (2006).

** The Menard Irrigation Company canal and laterals within the FM 2092 right of way are not eligible for listing on the National Register of Historic Places under Criterion D, but the irrigation system is potentially eligible for listing under other criteria. 
Site $41 \mathrm{MN} 55$ is a prehistoric campsite located on an older alluvial terrace just east of Fivemile Crossing. The site is exposed on both the north and south sides of FM 2092, and the finding of bone-tempered pottery and a Plainsstyle end scraper suggest that it represents a Toyah phase occupation. It appears that the deposits along the north and south fence lines have not been disturbed because the road was cut down deeply into the terrace, leaving intact deposits near the edge of the terrace well above the level of the road. Because of the possibility that this site contains a discrete Toyah phase occupation, it was recommended that it is potentially eligible for listing in the National Register and for designation as a SAL. It also was recommended that archeological testing was needed to define the nature and contextual integrity of the prehistoric deposits and provide sufficient data for a thorough assessment of National Register and SAL eligibility. A testing effort of 10 test units (each $1 \times 1 \mathrm{~m}$ and hand dug to ca. $40 \mathrm{~cm}$ below surface for a total of 4.0 cubic meters) was recommended as an appropriate level of work and was carried out in November 2006. Results of this work are reported in McWilliams et al. (2007).

\section{HISTORIC SITES}

Excluding the Menard Irrigation Company and Mission San Sabá (discussed below), there were 11 sites with historic components (see Tables 3 and 5). At seven previously recorded sites documented as being adjacent to FM 2092, minimal or no evidence of the historic component was found inside the right of way. In some cases, minimal effort was expended to search for late-nineteenth or early-twentieth-century remains inside the right of way because the deposits in the right of way are extensively disturbed. The portions of these seven sites (41MN5, 41MN9, 41MN10, 41MN12, 41MN13, $41 \mathrm{MN} 15$, and $41 \mathrm{MN} 20$ ) inside the right of way were recommended as not eligible for listing in the National Register or for designation as SALs.

Historic components were found at four of the newly recorded sites. Historic artifacts were observed on surface or in auger and shovel tests. At each of these sites, the archeological remains found within the right of way are limited to nondiagnostic artifacts that date generically to the late nineteenth or early twentieth centuries. Although historic features associated with some of these sites were observed outside the right of way, no features were observed in the right of way, and all of the observed artifacts came from disturbed contexts. Given the evidence for extensive disturbance to the deposits (due to previous agricultural activities and subsequent construction of the county road and FM 2092) throughout the project corridor, the potential for intact historic deposits and features inside the right of way was considered minimal. It was recommended that the historic components inside the right of way at each of these four sites (41MN53, 41MN54, 41MN60, and 41MN61) are not eligible for listing in the National Register or for designation as SALs.

\section{MN21, MENARD IRRIGATION COMPANY SYSTEM}

As recorded at TARL, 41MN21 includes the main irrigation canal of the Menard Irrigation Company, which was founded in the 1870s and is still in operation today. The many smaller lateral ditches that branch off the main system are not documented as part of the site, but they are clearly part of the same system. Historic archival and oral history research identified many gaps in the records of the Menard Irrigation Company. No maps of the entire irrigation system were found, and the company records do not clearly define the construction sequence and history of different parts of the system. No attempt was made during this project to map all of the lateral ditches that are outside the FM 2092 project area.

Based on a July 2004 letter agreement between TxDOT and THC, several relevant points were considered to establish the National Register eligibility potential for a historic irrigation system under Section 106 review. For the south Texas region, Jensen (2004:1) states that:

Cultural resource studies in this region will subsequently address the following points to establish eligibility for purposes of Section 106 review:

1. brief history of the origins of the system

2. a general understanding of the 
current and historic extent of the system 3 . known programs of improvements, based on interviews with the district management

4. establishment of historic integrity without further documentation requirements when these investigations reveal that at least $50 \%$ of the system as a whole continues to survive.

Although the Menard Irrigation Company system is in a different region of Texas, these requirements would still generally apply when considering its eligibility for listing in the $\mathrm{Na}$ tional Register. Based on the limited research conducted for the current FM 2092 project, and considering the eligibility requirements implemented by TxDOT and THC, PAI cannot adequately evaluate the National Register eligibility of the historic Menard Irrigation Company system at this time. More research is needed to develop a meaningful historic context for understanding the irrigation system relative to late-nineteenth- and early-twentieth-century agricultural developments. Comparisons between the Menard Irrigation Company system and other contemporaneous irrigation systems in the region would be helpful. At least two irrigation systems operated in nearby San Saba County: the Fleming San Saba Irrigation Company canal, dating to 1875 (Upchurch 1946) and the Sloan Ditch, dating to about 1880 (Greene 2001). In addition, a field reconnaissance survey is needed to establish the integrity of the various components of the irrigation system, most of which are on private property. Until this work can be done, it is appropriate to consider the irrigation district potentially eligible for listing in the National Register. A state historical subject marker attests to the historical importance of this nineteenth-century irrigation system (Texas Historical Commission 1972).

Although the FM 2092 project will involve restoring, resurfacing, and widening the paved road, it appears that the current construction plans will not impact any of the five identified irrigation system areas. As specified in Work Authorization No. 57536SA006, current construction plans specifically states that no bridges or culverts will be altered. Consequently, it was recommended that no further historical or archeological work is needed for the irrigation district in conjunction with this project.

\section{MN23, MISSION SAN SABA}

For this project, the Mission San Sabá search area was defined as approximately $400 \mathrm{~m}$ (0.3 miles) east to west along FM 2092, and it included the entire TxDOT right of way on the north and south sides of the road. This area is located immediately south of the main mission compound, which is located on private land and was intensively investigated by Texas Tech University archeologists from 1993 to 1997 under the direction of Grant D. Hall. Extensively investigated with both mechanical and hand excavations, the area where the main mission compound was located has been almost completely excavated (Grant Hall, personal communication 2006), but only the 1993 season of work has been reported (Hindes et al. 1995).

The PAI survey phase investigations (see Chapter 5) examined both north and south of the road, and extensive disturbances from the 1954 construction of FM 2092 were observed. Within the larger Mission Search Area, PAI archeologists excavated 19 gradall trenches, 11 test units, and 6 shovel tests. No evidence of Spanish colonial deposits was found south of the road. Intact deposits containing the Spanish colonial zone were found only in a narrow strip immediately adjacent to the north right-of-way fence. The Spanish colonial zone is a ca. 30-cmthick layer of Spanish artifacts and features defined by the previous Texas Tech investigations (Hindes et al. 1995:24-25).

At the conclusion of the survey phase, PAI archeologists recommended that the remains of Mission San Sabá within the FM 2092 right of way should be considered eligible for listing in the National Register and for designation as an SAL (Boyd et al. 2006). TxDOT and THC concurred with this recommendation, and TxDOT immediately issued a work authorization directing PAI to conduct archeological data recovery of the Spanish colonial remains within the FM 2092 right of way. The data recovery phase at Mission San Sabá was conducted between November 2006 and February 2007. PAI archeologists excavated 78 1x1-m units and 4 1x0.5$\mathrm{m}$ units. Extensive mechanical stripping was also conducted in a final effort to search for buried features in the TxDOT right of way north of FM 2092. Because this work investigated virtually all of the intact Spanish colonial deposits in the FM 2092 right of way, it effectively miti- 
gated the adverse affects that the FM 2092 road project will have on the cultural remains in the right of way. The details of all of the investigations, during the survey and data recovery phases, are presented in a separate report by McWilliams et al. (2007).

\section{HISTORIC LOCALITIES}

Seventeen historic localities were identified in archival documents or by informants along the 4.9-mile-long project area. While the research provided interesting, informative, and often conflicting historical data, none of these historic locations will be impacted by the proposed road construction. No further research or investigations were recommended for these localities.

\section{PUBLIC OUTREACH BROCHURE}

The year 2007 marked the 250th anniversary of the founding of the mission and presidio. The community of Menard and the Presidio de San Saba Restoration Board hosted several public events in the summer of 2007 to commemorate these historic events. A Pilgrimage Walk was held on June 8, 2007, and many people walked from the mission site to downtown Menard to rededicate the old Catholic Church that was recently renovated. The community and presidio restoration board also hosted the annual Texas Archeological Society field school at Presidio San Sabá June 9-16, 2007, which was directed by Texas Tech University archeologist Dr. Tamra Walter. TxDOT's Archeological Studies Branch and PAI viewed these large public events as an opportunity for public outreach associated with the FM 2092 road improvement project. In conjunction with the Phase II archeological data recovery investigations (see McWilliams et al. 2007), PAI researchers produced a popular brochure titled "The Menard Irrigation Canal: 250 Years of Agricultural History, 1757-2007" (Prewitt and Associates, Inc. 2007). This brochure outlined the history of the entire irrigation system and presented evidence that portions of the 1874 canal followed the "Old Spanish Ditch" built and used by the people living at Presidio San Sabá from 1757 to 1772 . Five thousand copies of this 4fold, 11x17-inch brochure were printed and delivered to the local community. Many of the brochures were distributed in the Menard area during the June 2007 events commemorating the founding of the mission and presidio. 



\section{REFERENCES CITED}

Bolton, Herbert Eugene

1914 The Founding of the Missions on the San Gabriel River, 1745-1749. Southwestern Historical Quarterly 17(4):323-378.

1970 Texas in the Middle Eighteenth Century: Studies in Spanish Colonial History and Administration. University of Texas Press, Austin and London. Originally published in 1915 as Volume 3 of the University of California Publications in History.

Boyd, Douglas K., Jennifer K. McWilliams, and Céline Finney

2006 Preliminary Report on Archeological Survey of 4.7 Miles of FM 2092 from Menard to Fivemile Crossing, Menard County, Texas. Prewitt and Associates, Inc., Austin. Submitted to the Archeological Studies Program, Environmental Affairs Division, Texas Department of Transportation, by Prewitt and Associates, Inc., September 2006.

Boyd, Douglas K., and Gemma Mehalchick

2007 Interim Report on Archeological Testing of 41FM55, a Toyah Phase Site in the FM 2092 Right of Way, Menard County, Texas. Submitted to the Archeological Studies Program, Environmental Affairs Division, Texas Department of Transportation, by Prewitt and Associates, Inc., September 2007.

Brown, Alicia

2006 "Menard County, Texas." Available from http://www.rootsweb.com/ txmenard [accessed various dates 2006-2007].

Bureau of Economic Geology

1981 Geologic Atlas of Texas, Llano Sheet. Bureau of Economic Geology, The University of Texas at Austin.
Callan, J. J.

1901 Correspondence to Adina de Zavala, 1901. Original in the Adina de Zavala papers, Box 2M133. The Center for American History, The University of Texas at Austin.

Caran, S. Christopher, Joe R. Wallace, and James Stotts

2000 Evidence of Spanish Colonial Mining at the James Stotts Ranch, Llano County, Texas. In Geology and Historical Mining, Llano Uplift Region, Central Texas, edited by J. Richard Kyle, pp. 65-73. Guidebook 20. Austin Geological Society, Austin, Texas.

Carlson, Shawn Bonath

1991 The Search for San Sabá: An Apache Mission on the San Saba River, Menard County, Texas. Archeological Surveys No. 9. Archeological Research Laboratory, Texas A\&M University, College Station.

Cox, I. Waynne

2004 The Spanish Acequias of San Antonio. Maverick Publishing Company, San Antonio.

Dennis, Philip A. (translator)

1995 Revenge of the Rio San Saba. In The Rediscovery of Santa Cruz de San Sabá, A Mission for the Apache in Spanish Texas, by Kay V. Hindes, Mark R. Wolf, Grant D. Hall, and Kathleen Kirk Gilmore, pp. 7984. Texas State Historical Association and Texas Tech University.

Dexter, John F.

1875a Vaughan's Agricultural and Mechanical Canal, Menardville, Tex (map). Filed October 28, 1875, under Canal Contract \#16, Vaughan Agricultural Mechanical Co. 
(Irrigation Co), Menard Co., Texas General Land Office, Austin.

1875b Survey Notes. Vaughan's Agricultural and Mechanical Canal, Menardville, Tex. Filed October 28, 1875 under Canal Contract \#16, Vaughan Agricultural Mechanical Co. (Irrigation Co), Menard Co., Texas General Land Office, Austin.

Doolittle, William E.

1995 The San Saba-Menard Irrigation System: Lessons Learned by Unraveling Its Origins. In Soil, Water, Biology, and Belief in Prehistoric and Traditional Southwestern Agriculture, edited by H. Wolcott Toll. New Mexico Archaeological Council, Albuquerque.

Dunn, William Edward

1914 The Apache Mission on the San Saba River; Its Founding and Failure. Southwestern Historical Quarterly 17(4):379-414.

Freeman, Martha Doty

1991 Legal Abstracts for Seven Tracts on the San Saba River. In The Search for San Sabá:An Apache Mission on the San Saba River, Menard County, Texas, by Shawn Bonath Carlson, pp. 91-106. Archeological Surveys No. 9. Archeological Research Laboratory, Texas A\&M University, College Station.

Gilmore, Kathleen

1967 A Documentary and Archaeological Investigation of Presidio de San Luis de las Amarillas and Mission Santa Cruz de San Sabá, Menard County, Texas. State Building Commission, Austin.

Greene, Daniel P.

2001 "Sloan, Texas." The Handbook of Texas Online. Available from http:// $\mathrm{w}$ w w. t s h a . u t e x a s . e d u / handbook/online/articles/SS/hrs49.html [accessed September 1, 2006].

Haley, Chet

1995 Notes from telephone interview July 3, 1995, by Mark Wolf. Mark Wolf Research Files.

Hall, Grant D.

2001 "Mission San Sabá.”Texas Beyond History Web exhibit. Texas Archeological Research Laboratory, The University of Texas at
Austin, and the Texas Archeological Society. Available from: http:// www.texasbeyondhistory.net/sansaba/ index.html [accessed March 4, 2006].

Hindes, V. Kay, Mark R. Wolf, Grant D. Hall, and Kathleen Kirk Gilmore

1995 The Rediscovery of Santa Cruz de San Sabá, A Mission for the Apache in Spanish Texas. Texas State Historical Association and Texas Tech University.

Jensen, Bruce

2004 Historic Irrigation Systems in South Texas. Letter from Bruce Jensen to Bob Brinkman, July 26, 2004. On file at the Environmental Affairs Division, Texas Department of Transportation, and the History Programs Division, Texas Historical Commission.

King, Henry C.

1876 "Field Inspection" addressed to Governor Richard Coke, July 19, 1876. Handwritten copy from Mark Wolf Research Files. Original document from the Canal Contract No. 16 file, Texas General Land Office, Austin.

Kniffen, Katherine

2006 Interview with Katherine Kniffen, June 7, 2006, at her residence east of Menard, Texas, by Douglas K. Boyd and Mark Wolf.

Lehne, Nella Mae

1982 "Menard's Big Ditch." In Menard County History: An Anthology, by Menard County Historical Society. Anchor Publishing Co., San Angelo, Texas.

Maestas, Enrique Gilbert-Michael

2003 Culture and History of Native American Peoples of South Texas. Ph.D. dissertation, The University of Texas at Austin.

McConnell, Joseph Carroll

1933 The West Texas Frontier: A Descriptive History of Early Times in Western Texas by Joseph Carroll McConnell, 1993 (Vol. 1) and 1939 (Vol. 2). Gazette Printing, Jacksboro, Texas. Available from http://www.forttours.com/pages/ mcconnellbook.asp [accessed various dates 2006-2007]

McWilliams, Jennifer K.

2001 Material Culture and Mission Inventories: A Comparison of Archaeological and 
Archival Data from the Mission Santa Cruz de San Sabá, Menard County, Texas. Master's thesis. Texas Tech University, Lubbock.

McWilliams, Jennifer K., Douglas K. Boyd, and Gemma Mehalchick

2007 Interim Report on Archeological Data Recovery of the Southern Portion of Mission Santa Cruz de San Sabá (41MN23) in the FM 2092 Right of Way, Menard County, Texas. Submitted to the Archeological Studies Program, Environmental Affairs Division, Texas Department of Transportation by Prewitt and Associates, Inc., September 2007.

Menard County

Court Records

Menard County Historical Society

1982 Menard County History: An Anthology. Anchor Publishing Co., San Angelo, Texas.

Menard Irrigation Company

2006 Menard Irrigation Company. Brochure produced and distributed by the Menard Irrigation Company, Menard, Texas. Compiled from "A Brief History of the Menard Irrigation Company" by C. A. Haley, notes from Ila Mae Davis, minutes of the Menard Irrigation Company meetings. On file at Prewitt and Associates, Inc., Austin, Texas.

Milford, Homer E.

2000 Mining and Smelting Techniques on the Northern Spanish Colonial Frontier. In Geology and Historical Mining, Llano Uplift Region, Central Texas, edited by J. Richard Kyle, pp. 1-16. Guidebook 20. Austin Geological Society, Austin, Texas.

Nathan, Paul D., and Lesley Byrd Simpson (translator and editor)

2000 The San Sabá Papers: A Documentary Account of the Founding and Destruction of San Sabá Mission. Southern Methodist University Press, Dallas.

Noguess, Mrs. Whittie Vaughan

1946 "Founder's Daughter Gives Her Version" in The Free State of Menard: A History of the County, compiled by N. H Pierce. Sixth Printing, 1989. Western Advertising Company, Menard, Texas.

Pierce, N. H.
1946 The Free State of Menard: A History of the County. Sixth Printing, 1989. Western Advertising Company, Menard, Texas.

Prewitt and Associates, Inc.

2007 "The Menard Irrigation Canal: 250 Years of Agricultural History, 1757-2007.” Popular brochure produced and distributed by Prewitt and Associates, Inc., Austin, Texas, and the Archeological Studies Branch, Environmental Affairs Division, Texas Department of Transportation, Austin, Texas.

Ratcliff, Sam D.

1991 Escenas de Martirio: Notes on The Destruction of Mission San Sabá. Southwestern Historical Quarterly 94(4):506-534.

Roberts, Capt. Dan W, and Mrs. D. W. Roberts

1987 Rangers and Sovereignty \& A Woman's Reminiscences of Six Years in Camp with the Texas Rangers. State House Press, Austin, Texas.

Rouse, Wra N.

2001 "King, Henry C." The Handbook of Texas Online. Available from http:// $\mathrm{w} \mathrm{w} \mathrm{w} \cdot \mathrm{t} \mathrm{s} \mathrm{h} \mathrm{a} \cdot \mathrm{u} \mathrm{t}$ e $\mathrm{x}$ a s . e d u / handbook/online/articles/KK/fki17.html [accessed May 25, 2007].

Schlenker, Greg C.

1991 Geomorphology of the Study Area. In The Search for San Sabá: An Apache Mission on the San Saba River, Menard County, Texas, by Shawn Bonath Carlson, pp. 2546. Archeological Surveys No. 9. Archeological Research Laboratory, Texas A\&M University, College Station.

Smyrl, Vivian Elizabeth

2001 "Sunnyside, Texas." Handbook of Texas Online. Available from http:// $\mathrm{w}$ w w. t s h a. u t e x a s.e d u / handbook/online/articles/SS/hrsxj.html [accessed September 1, 2006].

Texas Highway Department

1936 General Highway Map, Menard County, Texas. In cooperation with the U.S. Department of Agriculture, Bureau of Public Roads.

1954 Plans of Proposed State Highway Improvement: State Project FM Highway No. 2092, September 1954. Plans 
recommended for approval October 13, 1954, by District Engineer J. A. Snell, final completed May 6, 1955.

1958 General Highway Map: Menard County, Texas. In cooperation with the U.S. Department of Agriculture, Bureau of Public Roads.

Texas Historical Commission

1936 Real Presidio de San Saba.Texas historical marker No. 4212 erected by the Texas Historical Commission. Marker text available from http://atlas.thc.state.tx.us/ shell-county.htm [accessed April 10, 2006].

1962 Mission Santa Cruz de San Saba. Texas historical marker No. 4835 erected by the Texas Historical Commission. Marker text available from http://atlas.thc.state.tx.us/ shell-county.htm [accessed April 10, 2006].

1972 The Ditch. Texas historical marker No. 12 erected by the Texas Historical Commission. Marker text available from http://atlas.thc.state.tx.us/shellcounty.htm [accessed April 10, 2006].

Upchurch, Alice Gray

1946 Sketch History of San Saba County, Texas. Southwestern Historical Quarterly Online 50(1). Available from http:// www.tsha.utexas.edu/publications/ journals/shq/online/v050/n 1/ contrib_DIVL1264.html [accessed September 1, 2006].

U.S. Department of Agriculture

1967 Soil Survey of Menard County, Texas. U.S. Department of Agriculture, Soil Conservation Service, in cooperation with the Texas Agricultural Experiment Station, College Station.
U.S. Geological Survey

1987a Chapman Draw Quadrangle, 7.5-minute.

1987b Menard Quad, 7.5-minute.

Wade, Dr. Mariah F. (transcription and translation) 2007 Spanish Colonial Documents Pertaining to the Mission Santa Cruz de San Sabá (41MN23), Menard County, Texas. Archeological Studies Program Report No. 102. Environmental Affairs Division, Texas Department of Transportation, Austin. Reports of Investigations No. 154. Prewitt and Associates, Inc., Austin.

Walter, Tamra L., Elizabeth A. Cooper, Nancy Zayatz, and Grant D. Hall

2003 The Ruin of Ruins: Archaeological Excavations at Presidio San Sabá, 41MN1, Menard County, Texas. 2000-2002 Field Expeditions. San Saba Regional Survey Report 2.Archaeological Laboratory, Texas Tech University, Lubbock.

Walter, Tamra L., Mark Wolf, and Bennett Kimbell 2005 Spanish Colonial Presidio Architecture:An Example from Presidio San Sabá, Menard County, Texas. Bulletin of the Texas Archeological Society 76:29-44.

Weddle, Robert S.

1964 The San Sabá Mission: Spanish Pivot in Texas. University of Texas Press, Austin.

1999 The San Sabá Mission: Spanish Pivot in Texas. Texas A\&M University Press, College Station.

2006 "Santa Cruz de San Sabá Mission." The Handbook of Texas Online. Available from http://www.tsha.utexas.edu/handbook/ online/articles/SS/uqs36.html [accessed May 1, 2006]. 


\title{
APPENDIX A: Tabulated Historical Data for the San Saba River Valley Near Menard, Texas
}

\author{
Compiled by Jennifer K. McWilliams
}



This appendix presents historical and modern observations about historic events and locations along FM 2092 east of Menard. Some observations are keyed to identified historic sites or documented historical localities, but many are general references that cannot be linked to a specific location. Site locations are shown in Figure 7, and historic localities are shown in Figure 9.

This information was compiled during the research phase of this project. All of the historic resources included in this table are historic sites or general historic localities dating to the nine- teenth and early twentieth centuries during the period of Anglo-American settlement. Some observations that may pertain to the historic period or the earlier Spanish colonial period are included. However, observations that pertain only to Spanish colonial resources (such as the presidio and mission and associated roads and acequias), are excluded from this table. Observations on the Spanish colonial resources will be presented in a separate report on the archeological investigations at the mission site (41MN23). 
Table A.1. Observations on historical resources and features along FM 2092 between Menard and Fivemile Crossing

\begin{tabular}{|c|c|c|c|c|c|c|}
\hline $\begin{array}{c}\text { Site or } \\
\text { Historic } \\
\text { Locality } \\
\text { No. } \\
\end{array}$ & $\begin{array}{l}\text { Resource or } \\
\text { Feature }\end{array}$ & Observation & Interpretation & Observer & $\begin{array}{c}\text { Date of } \\
\text { Observation }\end{array}$ & Source \\
\hline 41MN5 & Cotton gin & $\begin{array}{l}\text { "The historic component of this site is focused } \\
\text { upon an extant cotton gin located east of } \\
\text { Menard. Three associated scatters were } \\
\text { identified with the cotton gin and all are } \\
\text { restricted to an area bounded on the south by } \\
\text { State Highway [sic] } 2092 \text {, on the east by the } \\
\text { Menard Irrigation Company Canal, on the } \\
\text { north by the San Saba River, and on the west } \\
\text { by a road dividing two properties. The owner } \\
\text { referred to this area as her 'dry' field. Three } \\
\text { distinct historic artifact scatters were found in } \\
\text { the field and probably represent the remains } \\
\text { of a farmstead associated with the gin. The } \\
\text { scatter nearest State Highway } 2092 \text { had the } \\
\text { greatest density and no doubt represents the } \\
\text { house site while the other two may have been } \\
\text { outbuildings... [extensive artifact list]. The } \\
\text { artifacts examined in the field were scattered } \\
\text { from State Highway } 2092 \text { northward to a } \\
\text { fenceline which traversed the highest portion } \\
\text { of the field at an angle parallel to the } \\
\text { highway." }\end{array}$ & $\begin{array}{l}\text { Historic/prehistoric site } \\
\text { recorded by } \\
\text { Carlson/Texas A\&M; } \\
\text { historic cotton gin and } \\
\text { associated artifact } \\
\text { scatter }\end{array}$ & Shawn Carlson & June 13,1990 & Carlson (1991:54-55) \\
\hline 41MN5 & Cotton gin & $\begin{array}{l}\text { "This land was real fertile in here. My daddy } \\
\text { and them farmed this field right in here } \\
\text { [across FM } 2092 \text { from Lyckman's house]. } \\
\text { Across the road over there. And man they used } \\
\text { to raise alfalfa and cotton. And Mr. Noyes had } \\
\text { the gin over there. And that's right across the } \\
\text { fence from my place. The old cement—or } \\
\text { rocks-are still there." }\end{array}$ & $\begin{array}{l}\text { All the land in this } \\
\text { valley is very fertile. } \\
\text { The rocks of the old } \\
\text { cotton gin can still be } \\
\text { seen. }\end{array}$ & Jerry Rambo & June 7, 2006 & $\begin{array}{l}\text { Interview with Jerry } \\
\text { Rambo by Jenny } \\
\text { McWilliams and Kay } \\
\text { Hindes, June 7, } 2006\end{array}$ \\
\hline
\end{tabular}




\section{Table A.1, continued}

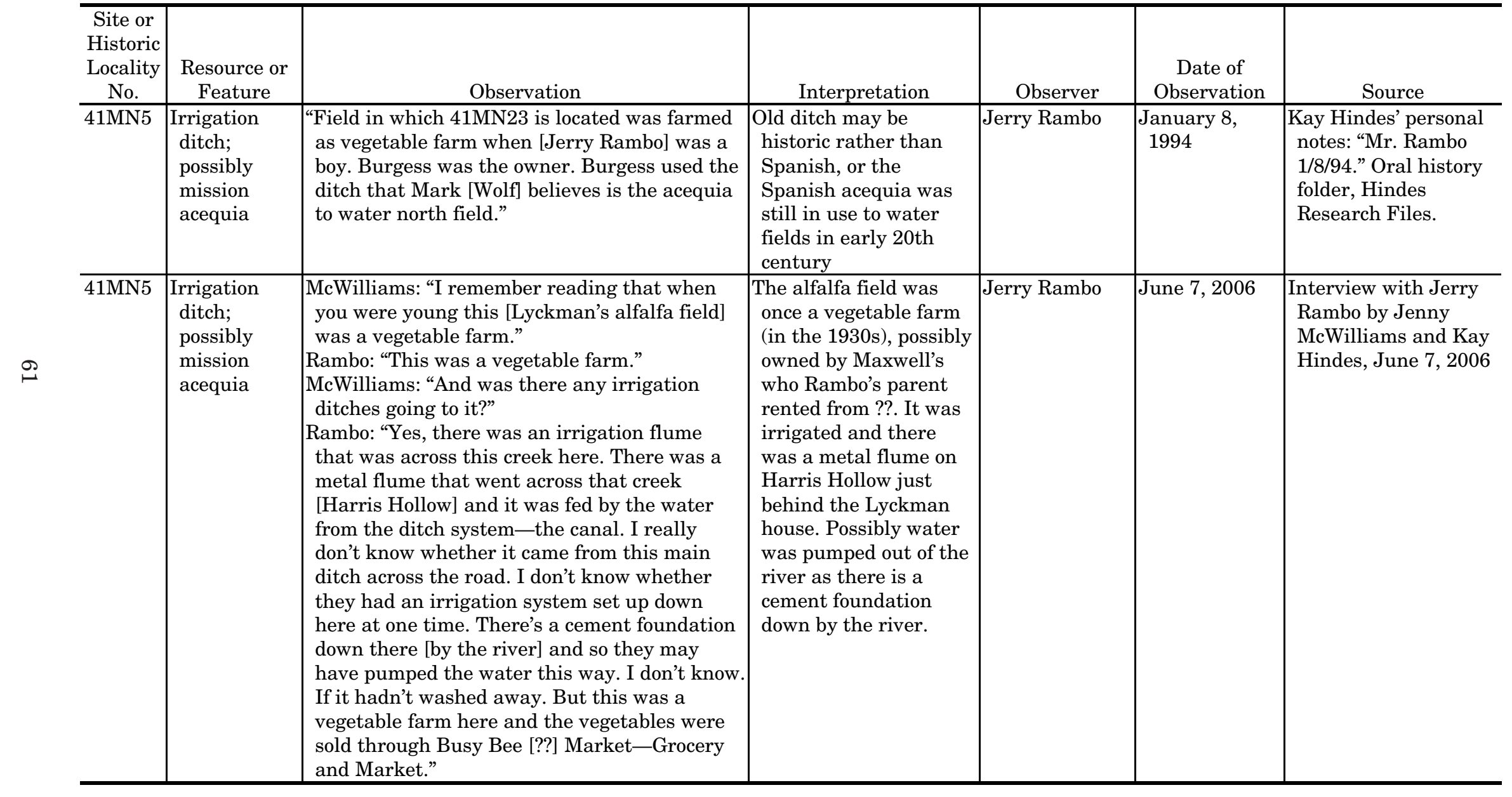


Table A.1, continued

\begin{tabular}{|c|c|c|c|c|c|c|}
\hline $\begin{array}{c}\text { Site or } \\
\text { Historic } \\
\text { Locality } \\
\text { No. }\end{array}$ & $\begin{array}{c}\text { Resource or } \\
\text { Feature }\end{array}$ & Observation & Interpretation & Observer & $\begin{array}{c}\text { Date of } \\
\text { Observation }\end{array}$ & Source \\
\hline $41 \mathrm{MN} 9$ & Historic site & $\begin{array}{l}\text { "This historic farmstead, located east of } \\
\text { Menard, was originally constructed in the } \\
1880 \text { s or 1890s by a man named Gus Noyas } \\
\text { (Mrs. McDaniel, personal communication). } \\
\text { The original structure rests atop a limestone- } \\
\text { lined basement while the remainder of the } \\
\text { house appears to have been added at various } \\
\text { stages throughout the years (Figure } 21 \text { ). Six } \\
\text { STs were excavated and reached } 20-35 \mathrm{cmbs} \text {. } \\
\text { Historic and prehistoric artifacts were } \\
\text { recovered." }\end{array}$ & $\begin{array}{l}\text { Historic/prehistoric site } \\
\text { recorded by } \\
\text { Carlson/Texas A\&M; } \\
\text { historic farmstead; } \\
\text { Gus Noyes farmstead } \\
\text { constructed 1880s- } \\
\text { 1890s; burned rock } \\
\text { scatter }\end{array}$ & Shawn Carlson & June 13, 1990 & Carlson (1991:61-63) \\
\hline $41 \mathrm{MN} 10$ & Historic site & $\begin{array}{l}\text { "This site is located in a field east of Menard } \\
\text { and characterized by a low rock strewn mound } \\
\text { visible from State Highway } 2092 \text { [sic]. The site } \\
\text { is believed to be the remains of a house, or } \\
\text { possibly a stone corral and dump. Historic } \\
\text { artifacts were quite dense and visibility was } \\
100 \% \text { in the southeast corner of the field. } \\
\text { Artifacts observed include aqua (1880-1916) } \\
\text { [cites source], lavender (1880-1918) [cites } \\
\text { source], and brown bottle glass, Bristol-glazed } \\
\text { stoneware (ca. 1880-1920) [cites source], } \\
\text { Albany-slipped stoneware (1900+) [cites } \\
\text { source], blue transferprinted whiteware } \\
\text { (1900+) [cites source], brick fragments, and } \\
\text { metal debris. [Goes on to describe artifacts } \\
\text { collected in detail]. These artifacts suggest a } \\
\text { turn-of-the-century use of the site." }\end{array}$ & $\begin{array}{l}\text { Historic site recorded by } \\
\text { Carlson/Texas A\&M; } \\
\text { turn-of-the-century } \\
\text { farmstead; historic } \\
\text { farmstead; mound } \\
\text { represents remains of } \\
\text { a house, or possibly a } \\
\text { stone corral and dump; } \\
\text { dense artifact scatter }\end{array}$ & Shawn Carlson & June 13, 1990 & Carlson (1991:63-64) \\
\hline
\end{tabular}


Table A.1, continued

\begin{tabular}{|c|c|c|c|c|c|c|}
\hline \begin{tabular}{c|} 
Site or \\
Historic \\
Locality \\
No.
\end{tabular} & $\begin{array}{l}\text { Resource or } \\
\text { Feature }\end{array}$ & Observation & Interpretation & Observer & $\begin{array}{c}\text { Date of } \\
\text { Observation }\end{array}$ & Source \\
\hline 41MN12 & Historic site & $\begin{array}{l}\text { "This site is located east of Menard in a similar } \\
\text { setting to that of } 41 \mathrm{MN} 9 \text { [located on the north } \\
\text { side of FM } 2092 \text { near the eastern end of the } \\
\text { project area]. The house sits atop a terrace } \\
\text { with a steep drop-off to a spring-fed tank on } \\
\text { the north (Figure } 22 \text { ). Although the brick } \\
\text { house appears to be of relatively recent date } \\
\text { (ca. 1930s), there was a dense scatter of } \\
\text { historic artifacts all around it which dated } \\
\text { from approximately 1850 to the present. } \\
\text { Artifact observed include various whitewares } \\
\text { (1805-1900) [cites sources], aqua (18880- } \\
\text { 1916) [cites source], brown, and lavender } \\
\text { bottle glass (1880-1918) [cites source], } \\
\text { Albany-slipped stoneware (1900+) [cites } \\
\text { source], Bristol-glazed stoneware (1920+) } \\
\text { [cites source], salt-glazed stoneware (pre-1900) } \\
\text { [cites source], cut nails and building } \\
\text { hardware. Artifacts collected [are described at } \\
\text { length and include a 1907 Indianhead penny]. } \\
\text { Cores, chert, and retouched flakes were also } \\
\text { noted around the house. STs were shallow } \\
\text { (30-40 cm) and recovered artifacts." }\end{array}$ & $\begin{array}{l}\text { Historic/prehistoric site } \\
\text { recorded by } \\
\text { Carlson/Texas A\&M; } \\
\text { modern brick house } \\
\text { with } 1850 \text { s-to-present } \\
\text { artifact scatter; } \\
\text { prehistoric artifact } \\
\text { scatter }\end{array}$ & Shawn Carlson & June 13,1990 & Carlson (1991:65-68) \\
\hline $41 \mathrm{MN} 12$ & Structure & $\begin{array}{l}\text { "This used to be a dairy at one time back in the } \\
\text { 20s or the 30s-there was a dairy here. And } \\
\text { Sammy Hinkel-he's still living-his folks had } \\
\text { a dairy right there. And there was an old } \\
\text { home there. And this lake down behind this } \\
\text { home was fed by the ditch system there." }\end{array}$ & $\begin{array}{l}\text { There was a dairy on } \\
\text { the north side of the } \\
\text { road. A ditch-fed lake } \\
\text { lies behind the dairy. } \\
\text { This may be the } \\
\text { lcoation of } 41 \mathrm{MN} 12 \\
\text { recorded by Carlson. }\end{array}$ & Jerry Rambo & June 7, 2006 & $\begin{array}{l}\text { Interview with Jerry } \\
\text { Rambo by Jenny } \\
\text { McWilliams and Kay } \\
\text { Hindes, June 7, } 2006\end{array}$ \\
\hline
\end{tabular}


Table A.1, continued

\begin{tabular}{|c|c|c|c|c|c|c|}
\hline $\begin{array}{l}\text { Site or } \\
\text { Historic } \\
\text { Locality } \\
\text { No. }\end{array}$ & $\begin{array}{c}\text { Resource or } \\
\text { Feature }\end{array}$ & Observation & Interpretation & Observer & $\begin{array}{c}\text { Date of } \\
\text { Observation }\end{array}$ & Source \\
\hline $\begin{array}{l}41 \mathrm{MN} 13 \\
\text { and } \\
\text { HL } 8\end{array}$ & Structure & $\begin{array}{l}\text { "And there was a home here, also [on the south } \\
\text { side] because see your rock well there-that } \\
\text { was a water well and they had an old wooden } \\
\text { tower there for a windmill, too." }\end{array}$ & \begin{tabular}{|l|} 
Rambo described the old \\
houses that he \\
remembers between \\
the mission and the \\
original location of the \\
historical marker. The \\
home with the rock \\
well and old wooden \\
tower is Historic \\
Locality 8.
\end{tabular} & Jerry Rambo & June 7, 2006 & $\begin{array}{l}\text { Interview with Jerry } \\
\text { Rambo by Jenny } \\
\text { McWilliams and Kay } \\
\text { Hindes, June 7, } 2006\end{array}$ \\
\hline $\begin{array}{l}41 \mathrm{MN} 13 \\
\text { and } \\
\text { HL } 9\end{array}$ & Structure & $\begin{array}{l}\text { "Mr. Edminson, when I was a boy, he had a } \\
\text { home there-on the south side. And the } \\
\text { Wheless' owned a farm there [on the south } \\
\text { side of FM 2092], next to the Edminsons and } \\
\text { General Hewitt T. Wheless was a famous } \\
\text { general in our air force during World War II } \\
\text { and this is where he was raised.... And the } \\
\text { ditch system feeds all of these fields here. } \\
\text { There was a home here and there was a dairy } \\
\text { here when I was a boy. And there was a big } \\
\text { barn-metal barn-here where they milked } \\
\text { the cows. [At this point we were at the } \\
\text { crossing of the ditch and FM } 2092 \text { ]...And here } \\
\text { [to the south] is the Boyer [sp? Buirer] home [a } \\
\text { large two-story wooden house that leans 'a } \\
\text { little bit to the east' with a rock cottage } \\
\text { immediately to the right (west). And there was } \\
\text { a home here, also [on the south side] because } \\
\text { see your rock well there-that was a water } \\
\text { well and they had an old wooden tower there } \\
\text { for a windmill, too." }\end{array}$ & $\begin{array}{l}\text { Rambo described the old } \\
\text { houses that he } \\
\text { remembered between } \\
\text { the mission and the } \\
\text { original location of the } \\
\text { historical marker. } \\
\text { 41MN13 is Mr } \\
\text { Edminson's place. The } \\
\text { Boyer [sp?] house is } \\
\text { Historic Locality } 9 \text {, and } \\
\text { the home with the rock } \\
\text { well and old wooden } \\
\text { tower is Historic } \\
\text { Locality } 8 .\end{array}$ & Jerry Rambo & June 7, 2006 & $\begin{array}{l}\text { Interview with Jerry } \\
\text { Rambo by Jenny } \\
\text { McWilliams and Kay } \\
\text { Hindes, June 7, } 2006\end{array}$ \\
\hline
\end{tabular}




\section{Table A.1, continued}

\begin{tabular}{|c|c|c|c|c|c|c|}
\hline $\begin{array}{c}\text { Site or } \\
\text { Historic } \\
\text { Locality } \\
\text { No. } \\
\end{array}$ & $\begin{array}{c}\text { Resource or } \\
\text { Feature }\end{array}$ & Observation & Interpretation & Observer & $\begin{array}{c}\text { Date of } \\
\text { Observation }\end{array}$ & Source \\
\hline $\begin{array}{l}1 \mathrm{MN} 13 \\
\text { and } \\
\text { HL } 10\end{array}$ & Structure & $\begin{array}{l}\text { "Now see that old cellar there [see map]. There } \\
\text { used to be an old grocery store there. And that } \\
\text { was back in the wagon days... There used to } \\
\text { be a little grocery store there. Doug Matthews } \\
\text { was the owner of it. And there's the old cistern } \\
\text { right back of it and there's some of the cement } \\
\text { slab that's still left to it...probably [would have } \\
\text { been here] in the 1910s-'20s. Well it was still } \\
\text { there when I was a boy uh, I'd say in the '30s." }\end{array}$ & $\begin{array}{l}\text { There was an old } \\
\text { grocery store owned by } \\
\text { Doug Matthews on the } \\
\text { south side of the } \\
\text { highway. It was there } \\
\text { from the } 1910 \text { to the } \\
\text { 1930s. }\end{array}$ & Jerry Rambo & June 7, 2006 & $\begin{array}{l}\text { Interview with Jerry } \\
\text { Rambo by Jenny } \\
\text { McWilliams and Kay } \\
\text { Hindes, June 7, } 2006\end{array}$ \\
\hline $41 \mathrm{MN} 13$ & Historic site & $\begin{array}{l}\text { "This site is located east of Menard and just } \\
\text { south of Highway } 2092 \text { [TARL map shows it } \\
\text { south of the irrigation ditch]. A dense historic } \\
\text { scatter was found in a field and referred to by } \\
\text { the owner as the 'old home site' where her } \\
\text { grandfather had lived. However, she was } \\
\text { unable to recall the specific dates that he had } \\
\text { lived there or when it was demolished. } \\
\text { Visibility was 100\% in the plowed field and } \\
\text { artifacts observed include blue Bristol-glazed } \\
\text { stoneware (ca. 1880-1920) [cites source], } \\
\text { whiteware (1805-1900) [cites source], } \\
\text { lavender bottle glass (1880-1918) [cites } \\
\text { source], and assorted metal indicating an } \\
\text { early twentieth century occupation. To the } \\
\text { south of this field quantities of burned clay } \\
\text { were found scattered throughout. The owner, } \\
\text { who said that clay was near the surface in } \\
\text { different areas of the field, attributed its } \\
\text { presence to the bulldozing and burning of } \\
\text { mesquite trees several years earlier." }\end{array}$ & $\begin{array}{l}\text { Historic site recorded by } \\
\text { Carlson/Texas A\&M } \\
\text { immediately south of } \\
\text { ditch on south side of } \\
\text { FM } 2092 ; \text { historic } \\
\text { farmstead described as } \\
\text { "old home site"; dense } \\
\text { historic artifact scatter }\end{array}$ & Shawn Carlson & June 13, 1990 & Carlson (1991:68-69) \\
\hline
\end{tabular}


Table A.1, continued

\begin{tabular}{|c|c|c|c|c|c|c|}
\hline \begin{tabular}{c|} 
Site or \\
Historic \\
Locality \\
No. \\
\end{tabular} & $\begin{array}{l}\text { Resource or } \\
\text { Feature } \\
\end{array}$ & Observation & Interpretation & Observer & $\begin{array}{c}\text { Date of } \\
\text { Observation }\end{array}$ & Source \\
\hline $41 \mathrm{MN} 15$ & Historic site & $\begin{array}{l}\text { "This site is located east of Menard and } \\
\text { characterized by a burned rock scatter with } \\
\text { flakes, cores, and retouched flakes, but no } \\
\text { formal tools. It covers the entire knoll upon } \\
\text { which a brick house sits. On the north edge of } \\
\text { the knoll is a sparse scatter of historic } \\
\text { material which includes lavender bottle glass } \\
\text { (1880-1918) [cites source], whiteware [cites } \\
\text { source], and metal debris. One piece of } \\
\text { unglazed semiporcelain was collected." }\end{array}$ & $\begin{array}{l}\text { Historic/prehistoric site } \\
\text { recorded by } \\
\text { Carlson/Texas A\&M on } \\
\text { north side of FM 2092; } \\
\text { sparse historic scatter }\end{array}$ & Shawn Carlson & June 13,1990 & Carlson (1991:70-71) \\
\hline $41 \mathrm{MN} 20$ & Historic site & $\begin{array}{l}\text { "This site is located east of Menard where } \\
\text { historic material was found scattered around } \\
\text { several metal barns adjacent to the highway. } \\
\text { Artifacts observed include whiteware (1805- } \\
\text { 1900) [cites sources], Bristol-glazed stoneware } \\
\text { (1920+) [cites sources], Albany-slipped } \\
\text { stoneware (1900) [cites source], lavender } \\
\text { bottle glass (1880-1918) [cites source], and cut } \\
\text { nails. Numerous foundations, of relatively } \\
\text { recent origin, were noted. However, one which } \\
\text { appears to be somewhat older, possibly turn of } \\
\text { the century, was observed in the grass east of } \\
\text { the driveway." }\end{array}$ & $\begin{array}{l}\text { Historic site recorded by } \\
\text { Carlson/Texas A\&M on } \\
\text { north side of FM 2092; } \\
\text { historic turn-of-the- } \\
\text { century farmstead. }\end{array}$ & Shawn Carlson & June 13,1990 & Carlson (1991:73-74) \\
\hline 41MN21 & $\begin{array}{l}\text { Irrigation } \\
\text { ditch }\end{array}$ & $\begin{array}{l}\text { "[Chet Halley] confirmed present ditch did } \\
\text { make use of Spanish acequia. Chet did } \\
\text { extensive research on similar subject but } \\
\text { found very little on actual ditch construction." }\end{array}$ & $\begin{array}{l}\text { Ditch tied into Spanish } \\
\text { acequia }\end{array}$ & Chet Halley & July 3,1995 & $\begin{array}{l}\text { Mark Wolf's personal } \\
\text { notes on phone } \\
\text { coversation with Chet } \\
\text { Halley, "80 years old" } \\
\text { on July 3, } 1995 \\
\end{array}$ \\
\hline $41 \mathrm{MN} 21$ & $\begin{array}{l}\text { Irrigation } \\
\text { ditch }\end{array}$ & $\begin{array}{l}\text { "[Ditch] empties in Boyd McDaniels now. Used } \\
\text { to go below that and across the river on east } \\
\text { side" }\end{array}$ & $\begin{array}{l}\text { Ditch once extended } \\
\text { farther }\end{array}$ & Chet Halley & July 3,1995 & $\begin{array}{l}\text { Mark Wolf's personal } \\
\text { notes on phone } \\
\text { coversation with Chet } \\
\text { Halley, "80 years old" } \\
\text { on July } 3,1995\end{array}$ \\
\hline
\end{tabular}


Table A.1, continued

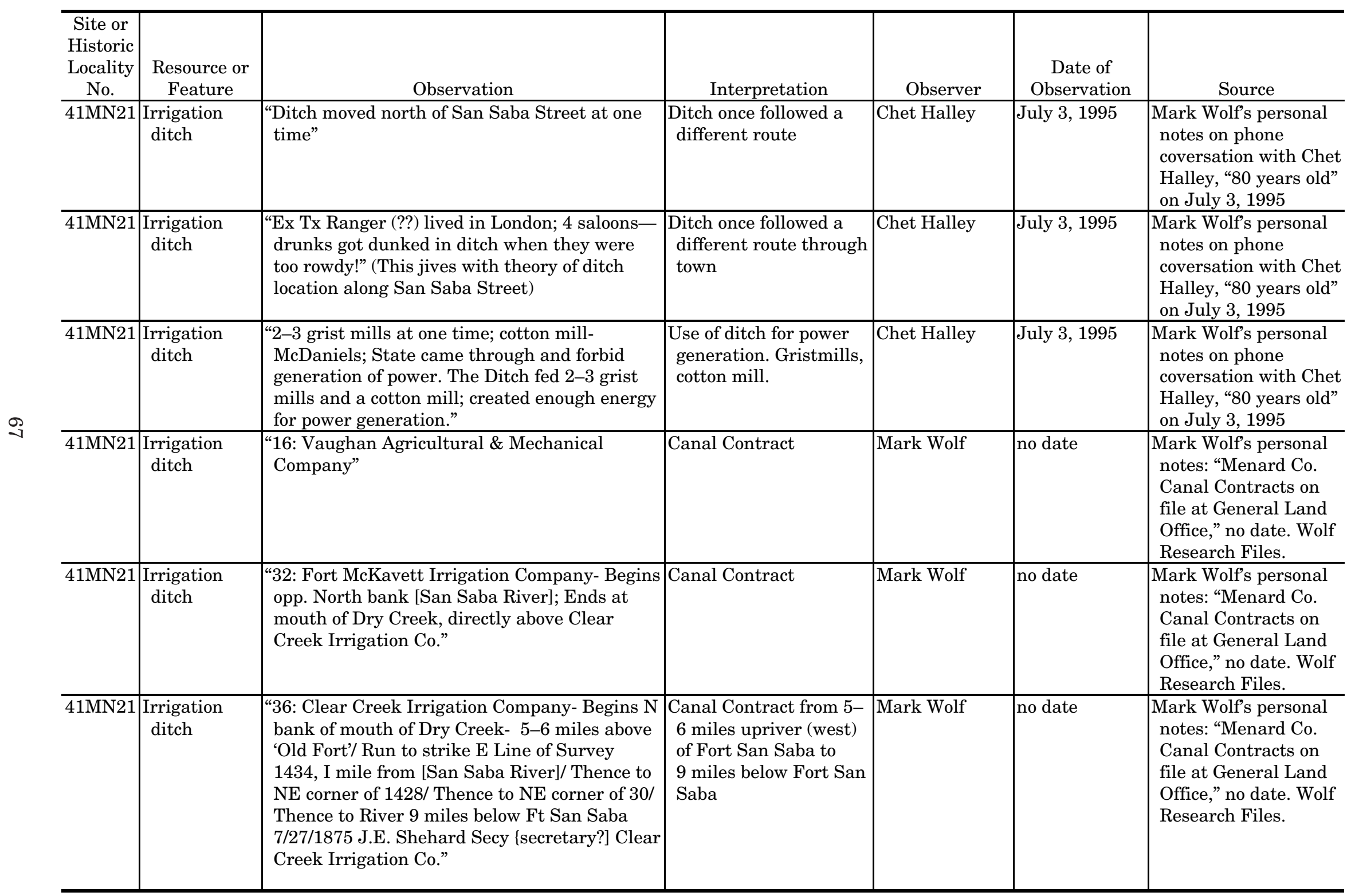


Table A.1, continued

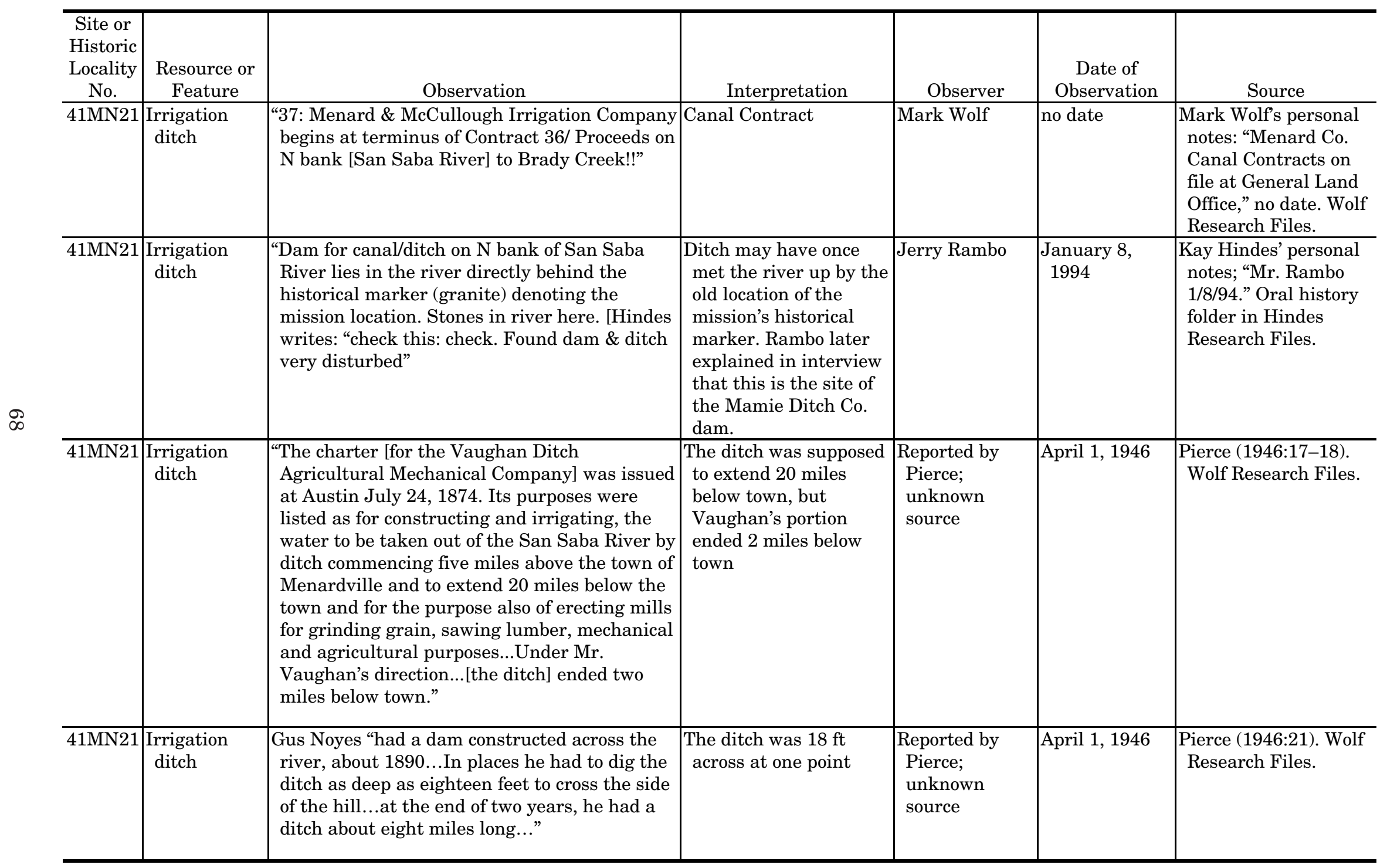


Table A.1, continued

\begin{tabular}{|c|c|c|c|c|c|c|}
\hline $\begin{array}{c}\text { Site or } \\
\text { Historic } \\
\text { Locality } \\
\text { No. } \\
\end{array}$ & $\begin{array}{l}\text { Resource or } \\
\text { Feature }\end{array}$ & Observation & Interpretation & Observer & $\begin{array}{c}\text { Date of } \\
\text { Observation }\end{array}$ & Source \\
\hline $41 \mathrm{MN} 21$ & $\begin{array}{l}\text { Irrigation } \\
\text { ditch }\end{array}$ & $\begin{array}{l}\text { "Later, other irrigation companies were formed } \\
\text { lower down the river, including the Kitchens } \\
\text { Irrigation and Manufacturing Company which } \\
\text { dug a ditch from Jackson dam, five miles } \\
\text { below Menardville. It's charter was granted in } \\
\text { 1884." }\end{array}$ & $\begin{array}{l}\text { Kitchens Irrigation and } \\
\text { Manufactoring Co. dug } \\
\text { existing ditch within } \\
\text { the project area }\end{array}$ & \begin{tabular}{|l} 
Reported by \\
Pierce; \\
unknown \\
source
\end{tabular} & April 1, 1946 & $\begin{array}{l}\text { Pierce (1946:21). Wolf } \\
\text { Research Files. }\end{array}$ \\
\hline $41 \mathrm{MN} 21$ & $\begin{array}{l}\text { Irrigation } \\
\text { ditch }\end{array}$ & $\begin{array}{l}\text { The ditch has followed the same course } \\
\text { throughout Rambo's life. "It hadn't ever } \\
\text { changed." } \\
\text { McWilliams: "Were there any laterals that shot } \\
\text { off differently?" } \\
\text { Rambo: "Well there could be back on the farms } \\
\text { but I don't know of any here in town...most of } \\
\text { the land here in town is upgraded and the } \\
\text { water wouldn't have flowed this way." }\end{array}$ & $\begin{array}{l}\text { Rambo doesn't } \\
\text { remember the ditch } \\
\text { ever following a } \\
\text { different route, } \\
\text { although there could } \\
\text { have been changes } \\
\text { made on the farms. }\end{array}$ & Jerry Rambo & June 7, 2006 & \begin{tabular}{|l} 
Interview with Jerry \\
Rambo by Jenny \\
McWilliams and Kay \\
Hindes, June 7, 2006
\end{tabular} \\
\hline
\end{tabular}




\section{Table A.1, continued}

\begin{tabular}{|c|c|c|c|c|c|c|}
\hline $\begin{array}{c}\text { Site or } \\
\text { Historic } \\
\text { Locality } \\
\text { No. }\end{array}$ & $\begin{array}{l}\text { Resource or } \\
\text { Feature }\end{array}$ & Observation & Interpretation & Observer & $\begin{array}{c}\text { Date of } \\
\text { Observation }\end{array}$ & Source \\
\hline $41 \mathrm{MN} 21$ & $\begin{array}{l}\text { Irrigation } \\
\text { ditch }\end{array}$ & $\begin{array}{l}\text { "When the Republic of Texas came into the } \\
\text { Union of the States, she reserved all her } \\
\text { public domain, and appropriated it to the } \\
\text { upbuilding of the state, in public institutions } \\
\text { and school funds. And Uncle Sam was not } \\
\text { more liberal in giving the people homes. I } \\
\text { think it was the Fourteenth Legislature that } \\
\text { offered land subsidy, to encourage irrigation, } \\
\text { specifying the dimensions of a ditch to carry } \\
\text { the water, say six feet wide, at the bottom of } \\
\text { the ditch, and twelve feet wide, from cut to cut } \\
\text { across the top, and four feet deep, on level } \\
\text { ground. For this class of ditch, the state } \\
\text { offered three sections of land to the mile of } \\
\text { ditch, not otherwise appropriated, to the } \\
\text { makers of that grade of ditches. The state not } \\
\text { reserving any rental, or any further claim on } \\
\text { the enterprise. Under this covenant, between } \\
\text { the state and the citizen we had the pleasure } \\
\text { of seeing the first ditch made, and stood guard } \\
\text { for the workers in their happy vocation." }\end{array}$ & \begin{tabular}{|l|} 
Funding for the "ditch" \\
came from the U.S. \\
government in the \\
form of "three sections \\
of land to the mile of \\
ditch." The \\
government stated the \\
size of the ditch. The \\
Texas Rangers \\
guarded the \\
construction of the first \\
ditch. Although no \\
date is given in this \\
excerpt, the Rangers \\
were camped east of \\
Menard from 1875 to \\
1877. However, less \\
likely, it could have \\
been when they were \\
camped near Fort \\
McKavett in 1878.
\end{tabular} & $\begin{array}{l}\text { Capt. Dan } \\
\text { Roberts }\end{array}$ & $1875-1877$ & $\begin{array}{l}\text { Roberts and Roberts } \\
(1987: 85)\end{array}$ \\
\hline $41 \mathrm{MN} 21$ & $\begin{array}{l}\text { Irrigation } \\
\text { ditch }\end{array}$ & $\begin{array}{l}\text { “33: Menard County Irrigation Company- } \\
\text { Begins S side of [San Saba River] @ NW } \\
\text { norner, or near it, of Survey 289/ Thence to } \\
\text { NW corner of } 277 / \text { Thence to NE corner of } 261 / \\
\text { Thence to NE corner of } 264 / \text { Thence to NE } \\
\text { corner of } 229 \text { / Thence into [San SabaRiver] @ } \\
\text { NE corner of 218. 7/27/1875 J.E. Shephard } \\
\text { Secy Menard Co Irrigation Co.” }\end{array}$ & Canal Contract & Mark Wolf & no date & $\begin{array}{l}\text { Mark Wolf's personal } \\
\text { notes: "Menard Co. } \\
\text { Canal Contracts on } \\
\text { file at General Land } \\
\text { Office," no date. Wolf } \\
\text { Research Files. }\end{array}$ \\
\hline
\end{tabular}


Table A.1, continued

\begin{tabular}{|c|c|c|c|c|c|c|}
\hline $\begin{array}{c}\text { Site or } \\
\text { Historic } \\
\text { Locality } \\
\text { No. } \\
\end{array}$ & $\begin{array}{c}\text { Resource or } \\
\text { Feature } \\
\end{array}$ & Observation & Interpretation & Observer & $\begin{array}{c}\text { Date of } \\
\text { Observation }\end{array}$ & Source \\
\hline 41MN21 & $\begin{array}{l}\text { Irrigation } \\
\text { ditch }\end{array}$ & $\begin{array}{l}\text { "The Menard Irrigation Company Canal } \\
\text { originated as a result of the efforts of } \\
\text { William J. Vaughan who chartered the } \\
\text { Vaughan Ditch Agricultural Mechanical } \\
\text { Company with a term of } 30 \text { years beginning } \\
\text { July 24, } 1874 \text { (Records of the Secretary State). } \\
\text { The Menard Irrigation Company was } \\
\text { subsequently chartered in 1904, and } \\
\text { rechartered in 1954, to maintain and operate } \\
\text { dams, reservoirs, lakes, wells, canals, flumes, } \\
\text { laterals and other functions necessary for the } \\
\text { purpose of irrigation, milling, and } \\
\text { stockraising. The water for these operations } \\
\text { was to come from the San Saba River by a } \\
\text { ditch commencing } 4.5 \text { miles above the town of } \\
\text { Menardville, Menard County, Texas, on the } \\
\text { south side of the San Saba River, and } \\
\text { extending five miles below the town of } \\
\text { Menardville (Records of the Secretary State, } \\
\text { Domestic Charter \#13602). This ditch, begun } \\
\text { in } 1874 \text {, was in place at least by 1913 when it } \\
\text { was mapped by W.P. Doty, County Surveyor, } \\
\text { for the Mamie Irrigation and Mill Co. (Menard } \\
\text { County Deed Record 27:445).” }\end{array}$ & $\begin{array}{l}\text { Historic site recorded by } \\
\text { Carlson/Texas A\&M; } \\
\text { ditch, flows south of } \\
\text { FM } 2092\end{array}$ & Shawn Carlson & June 13,1990 & Carlson (1991:74-75) \\
\hline$\overline{\text { HL } 1}$ & Grave & Tull Smith grave & $\begin{array}{l}\text { Historic grave observed } \\
\text { by John Arnn during } \\
\text { TxDOT reconnaissance } \\
\text { immediately north of } \\
\text { FM } 2092 \text { near west } \\
\text { end of project area. } \\
\text { Marked graves are } \\
\text { Historic Locality } 1 .\end{array}$ & John Arnn & March 2006 & $\begin{array}{c}\text { John Arnn, personal } \\
\text { communication } 2006\end{array}$ \\
\hline
\end{tabular}


Table A.1, continued

\begin{tabular}{|c|c|c|c|c|c|c|}
\hline \begin{tabular}{c|} 
Site or \\
Historic \\
Locality \\
No. \\
\end{tabular} & $\begin{array}{c}\text { Resource or } \\
\text { Feature }\end{array}$ & Observation & Interpretation & Observer & $\begin{array}{c}\text { Date of } \\
\text { Observation } \\
\end{array}$ & Source \\
\hline$\overline{\mathrm{HL}} 1$ & Grave & Tullos B. Smith ambushed and killed & $\begin{array}{l}\text { Horse thieves or } \\
\text { Indians attack; } \\
\text { tombstone east of } \\
\text { Menard }\end{array}$ & $\begin{array}{l}\text { Alicia Brown, } \\
\text { annotated } \\
\text { excerpt from } \\
\text { The West } \\
\text { Texas Frontier } \\
\text { by Joseph } \\
\text { Carroll } \\
\text { McConnell }\end{array}$ & $\begin{array}{l}\text { February 13, } \\
1990\end{array}$ & $\begin{array}{l}\text { from Dr. Jake } \\
\text { Landers; original } \\
\text { source is McConnell } \\
(1933)\end{array}$ \\
\hline$\overline{\text { HL } 1}$ & Grave & $\begin{array}{l}\text { "Located east of Menard on FM } 2092 \text { under a } \\
\text { stand of trees is a solitary headstone protected } \\
\text { by an iron fence. This is the burial location of } \\
\text { Tully V. [B.?] Smith, born January 14, } 1833 \\
\text { and died January 10, } 1871 \text {. His headstone } \\
\text { reads: 'No pain, no grief, no anxious fear; Can } \\
\text { reach the peace for Sleeper Here.'” }\end{array}$ & Tull Smith died in 1871 & Alicia Brown & $\begin{array}{l}\text { February } 19, \\
2005\end{array}$ & Brown (2006) \\
\hline HL 1 & Graves & Tull Smith grave & $\begin{array}{l}\text { Mark Wolf says there } \\
\text { are graves. } \\
\text { Family/homsteaders(?) } \\
\text { killed by robbers? }\end{array}$ & Mark Wolf & May 19, 2006 & $\begin{array}{c}\text { Mark Wolf, personal } \\
\text { communication } 2006\end{array}$ \\
\hline HL 2 & Grave & $\begin{array}{l}\text { "One lady told of some travelers who came to } \\
\text { Menard, bringing with them a woman of } \\
\text { undetermined age who had been scalped. They } \\
\text { had found her lying on the banks of Scalp } \\
\text { Creek, but she died shortly thereafter. } \\
\text { Another man said that his brother-in-law told } \\
\text { him that the woman scalped by the Indians } \\
\text { was a sixteen year old white girl who had red } \\
\text { hair. He thinks she was buried about one-half } \\
\text { mile east of Menard on the Five Mile Road." }\end{array}$ & $\begin{array}{l}\text { Grave, possibly the } \\
\text { same location as Tull } \\
\text { Smith's grave? }\end{array}$ & $\begin{array}{l}\text { Menard County } \\
\text { History: An } \\
\text { Anthol'ogy, } \\
1982\end{array}$ & June 4, 1905 & $\begin{array}{l}\text { From Jake Landers; } \\
\text { original source is } \\
\text { Menard County } \\
\text { Historical Society } \\
(1982: 29)\end{array}$ \\
\hline HL 3 & Graves & Adam Bradford family buried next to Tull & $\begin{array}{l}\text { Three children of Adam } \\
\text { Bradford's plus Tullos, } \\
\text { and possibly scalped } \\
\text { woman, all buried } \\
\text { along "Five Mile } \\
\text { Road." }\end{array}$ & Alicia Brown & $\begin{array}{l}\text { February } 19, \\
2005\end{array}$ & Brown (2006) \\
\hline
\end{tabular}


Table A.1, continued

\begin{tabular}{|c|c|c|c|c|c|c|}
\hline $\begin{array}{c}\text { Site or } \\
\text { Historic } \\
\text { Locality } \\
\text { No. }\end{array}$ & $\begin{array}{l}\text { Resource or } \\
\text { Feature }\end{array}$ & Observation & Interpretation & Observer & $\begin{array}{c}\text { Date of } \\
\text { Observation }\end{array}$ & Source \\
\hline HL 3 & Graves & $\begin{array}{l}\text { "Adam Bradford reared seventeen children to } \\
\text { be adults. He has one daughter still living in } \\
\text { San Angelo, two or three small children of his } \\
\text { are buried east of Menard in what is now a } \\
\text { field. The small tombstones can still be seen } \\
\text { under some live oak trees.” }\end{array}$ & $\begin{array}{l}\text { Two or three child } \\
\text { burials may be in the } \\
\text { vicinity of Tull Smith's } \\
\text { grave }\end{array}$ & $\begin{array}{l}\text { Menard News, } \\
\text { Centennial } \\
\text { Edition, } \\
\text { November 11, } \\
1971\end{array}$ & May 24, 1905 & $\begin{array}{l}\text { Excerpt from Menard } \\
\text { News, Centennial } \\
\text { Edition, November 11, } \\
\text { 1971; see Brown } \\
(2006)\end{array}$ \\
\hline HL 4 & Graves & $\begin{array}{l}\text { "To the east of Tull Smith's headstone is a } \\
\text { cement slab. At this time I don't know if this is } \\
\text { another individual....or individuals...since } \\
\text { there are no other headstones. Also, located to } \\
\text { the east of the metal fence are two other } \\
\text { cement slabs that do not belong in the area. It } \\
\text { is speculation on my part that this might also } \\
\text { mark someone's burial location." }\end{array}$ & $\begin{array}{l}\text { There may be another } \\
\text { individual in addition } \\
\text { to Tull Smith and the } \\
\text { possible Bradford } \\
\text { children-as well as } \\
\text { the scalped woman }\end{array}$ & Alicia Brown & $\begin{array}{l}\text { February 19, } \\
2005\end{array}$ & Brown (2006) \\
\hline HL 4 & Graves & $\begin{array}{l}\text { "[There are burials] between here and town and } \\
\text { they have markers on them. Now they have } \\
\text { moved one of the markers from there. } \\
\text { Someone stoled it. But one of them is still } \\
\text { there." }\end{array}$ & $\begin{array}{l}\text { There were once two } \\
\text { grave markers near } \\
\text { Tull Smith's grave. }\end{array}$ & Jerry Rambo & June 7, 2006 & $\begin{array}{l}\text { Interview with Jerry } \\
\text { Rambo by Jenny } \\
\text { McWilliams and Kay } \\
\text { Hindes, June 7, } 2006\end{array}$ \\
\hline HL 4 & Graves & $\begin{array}{l}\text { "This is where your river makes a bend and } \\
\text { goes north there. We're right on that curve in } \\
\text { the road. And right straight in front of us } \\
\text { where those live oaks are is where your graves } \\
\text { are...on the north side of the road.... My uncle } \\
\text { and aunt owned the property at one time. And } \\
\text { they didn't want those graves disturbed but } \\
\text { people were taking the steel fences and one of } \\
\text { the steel fences is still around the marker.... } \\
\text { See there's a stone there, well there were two } \\
\text { of those when my aunt and uncle owned the } \\
\text { property. } \\
\text { McWilliams: "And were there any other graves } \\
\text { out there or just those two?" } \\
\text { Rambo: "Just those two." }\end{array}$ & $\begin{array}{l}\text { There were originally } \\
\text { two grave markers and } \\
\text { more fencing around } \\
\text { the graves, but they } \\
\text { were stolen. }\end{array}$ & Jerry Rambo & June 7, 2006 & $\begin{array}{l}\text { Interview with Jerry } \\
\text { Rambo by Jenny } \\
\text { McWilliams and Kay } \\
\text { Hindes, June 7, } 2006\end{array}$ \\
\hline
\end{tabular}


Table A.1, continued

\begin{tabular}{|c|c|c|c|c|c|c|}
\hline $\begin{array}{c}\text { Site or } \\
\text { Historic } \\
\text { Locality } \\
\text { No. }\end{array}$ & $\begin{array}{l}\text { Resource or } \\
\text { Feature }\end{array}$ & Observation & Interpretation & Observer & $\begin{array}{c}\text { Date of } \\
\text { Observation }\end{array}$ & Source \\
\hline HL 5 & Road & \begin{tabular}{|l} 
McWilliams: "Now we're just coming up onto \\
the curve that leads into town." \\
Rambo: "OK, now this curve here has been \\
changed. I can show you the old wagon or \\
gravel road that was traveled when it was \\
gravel because they had a bridge over at that \\
time-over Harris Hollow to the south side of \\
the road.... And here's the old bridge." \\
McWilliams: "It's by a large pecan tree and you \\
can still see a little archway bridge of cement \\
with a little rock work on the edges." \\
Hindes: "And that was the original route of the \\
road." \\
Rambo: confirms and adds, "I traveled over it. I \\
got to travel over it."
\end{tabular} & $\begin{array}{l}\text { The old wagon road and } \\
\text { gravel road curved } \\
\text { more as it came closer } \\
\text { to town. There is an } \\
\text { old bridge that crossed } \\
\text { Harris Hollow. }\end{array}$ & Jerry Rambo & June 7, 2006 & $\begin{array}{l}\text { Interview with Jerry } \\
\text { Rambo by Jenny } \\
\text { McWilliams and Kay } \\
\text { Hindes, June 7, } 2006\end{array}$ \\
\hline HL 6 & \begin{tabular}{|l} 
Original \\
location of \\
historical \\
marker
\end{tabular} & $\begin{array}{l}\text { "I really never thought about the mission being } \\
\text { here [in the Lyckman's field] because when } \\
\text { they had the marker between here and town, } \\
\text { there was a set of live oak trees that set down } \\
\text { in the fields down there and they always said } \\
\text { that the mission was down there, but the } \\
\text { measurements didn't come out with when y'all } \\
\text { were going through that [sic]..." }\end{array}$ & $\begin{array}{l}\text { Rambo never } \\
\text { questioned the location } \\
\text { of the "missing" } \\
\text { mission because the } \\
\text { historical marker was } \\
\text { farther east, and } \\
\text { stories had indicated } \\
\text { that it was located } \\
\text { near a clump of live } \\
\text { oak trees down in the } \\
\text { field. }\end{array}$ & Jerry Rambo & June 7, 2006 & $\begin{array}{l}\text { Interview with Jerry } \\
\text { Rambo by Jenny } \\
\text { McWilliams and Kay } \\
\text { Hindes, June 7, } 2006\end{array}$ \\
\hline HL 6 & \begin{tabular}{|l} 
Original \\
location of \\
historical \\
marker
\end{tabular} & $\begin{array}{l}\text { "Founded among the Lipan Apache Indians by } \\
\text { Franciscan Missionaries in } 1757 \text { through the } \\
\text { financial aid of the Count of Regla. Sacked and } \\
\text { left in ruins by the Comanches in } 1758 . \text { Here } \\
\text { perished Padres Alonso Giraldo de Terreros } \\
\text { and Jose Santiesteban, martyrs to the } \\
\text { Christian cause." }\end{array}$ & $\begin{array}{l}\text { The historical marker } \\
\text { was erected in } 1936 \text { at } \\
\text { this location. It was } \\
\text { moved to its current } \\
\text { location in } 1997 .\end{array}$ & \begin{tabular}{|l}
1936 Texas \\
Centennial \\
subject marker
\end{tabular} & April 19, 2007 & $\begin{array}{l}\text { Texas Historical } \\
\text { Commission }(2006)\end{array}$ \\
\hline
\end{tabular}


Table A.1, continued

\begin{tabular}{|c|c|c|c|c|c|c|}
\hline $\begin{array}{c}\text { Site or } \\
\text { Historic } \\
\text { Locality } \\
\text { No. }\end{array}$ & $\begin{array}{l}\text { Resource or } \\
\text { Feature }\end{array}$ & Observation & Interpretation & Observer & $\begin{array}{c}\text { Date of } \\
\text { Observation }\end{array}$ & Source \\
\hline HL 7 & Structure & $\begin{array}{l}\text { "Now see this rock water well, or cooling... } \\
\text { [sic]...There was a home that set right there. } \\
\text { It's rock and see they plastered over and } \\
\text { painted over it. And if you'll look it's cut stone, } \\
\text { carved with the their hand. There was a home } \\
\text { set there. In fact some of my cousins owned } \\
\text { this property at one time. } \\
\text { Hindes: "There's some stones eroding out in the } \\
\text { right of way, Jenny. Do you see that?" } \\
\text { McWilliams: "Yes, and there's a GTE buried } \\
\text { cable line along the ROW right here." }\end{array}$ & \begin{tabular}{|l|} 
There is a rock water \\
well house on the \\
south side of the road. \\
Some rocks are eroding \\
into the right of way. \\
Although there is a \\
buried utility line \\
through here, this \\
should be investigated \\
for historic deposits.
\end{tabular} & Jerry Rambo & June 7, 2006 & $\begin{array}{l}\text { Interview with Jerry } \\
\text { Rambo by Jenny } \\
\text { McWilliams and Kay } \\
\text { Hindes, June 7, } 2006\end{array}$ \\
\hline HL 111 & Ditch & $\begin{array}{l}\text { Judge Lyckman "thought that old ditch was } \\
\text { part of irrigation system (Deeds in 1910-1920s } \\
\text { concur)" [see detailed sketch map] }\end{array}$ & $\begin{array}{l}\text { Primary irrigation ditch } \\
\text { may have had } \\
\text { additional offshoot at } \\
\text { one point }\end{array}$ & $\begin{array}{c}\text { Judge Lyckman } \\
\text { to Mark Wolf }\end{array}$ & July 26, 1993 & $\begin{array}{l}\text { Mark Wolf's personal } \\
\text { notes and annotated } \\
\text { map: "Field Survey } \\
\text { Lyckman Property," } \\
\text { July } 26,1997 . \text { Wolf } \\
\text { Research Files. } \\
\end{array}$ \\
\hline HL 12 & Smelter & $\begin{array}{l}\text { "Presidio. Smelter." Annotation on J. J. } \\
\text { Callan's } 1901 \text { hand-drawn map; this notation } \\
\text { is shown in the vicinity of the mission location. }\end{array}$ & $\begin{array}{l}\text { A smelter was thought } \\
\text { to be in the general } \\
\text { area of the mission in } \\
\text { the early 20th century. } \\
\text { Mission site could be } \\
\text { misidentied as a } \\
\text { smelter. } \\
\end{array}$ & J. J. Callan & $\begin{array}{l}\text { January 4, } \\
1901\end{array}$ & $\begin{array}{l}\text { Copy of J. J. Callan } \\
\text { (1901) map in Wolf } \\
\text { Research Files. }\end{array}$ \\
\hline HL 12 & Smelter & $\begin{array}{l}\text { "Hundreds of prospectors...have been here from } \\
\text { time to time within the past fifty } \\
\text { years... [looking for] the lost mine and hidden } \\
\text { treasure. But none ever succeeded in finding } \\
\text { anything to indicate the presence of either, } \\
\text { excepting the remains of the smelter, some } \\
\text { crucibles, a few small slabs of lead containg a } \\
\text { considerable per centum of silver, some tools } \\
\text { and impliments [sic] and parts of human } \\
\text { bones." }\end{array}$ & $\begin{array}{l}\text { A smelter was thought } \\
\text { to be in the general } \\
\text { area of the mission } \\
\text { (possibly the mission } \\
\text { site) in the early 20th } \\
\text { century. }\end{array}$ & J. J. Callan & $\begin{array}{l}\text { January 4, } \\
1901\end{array}$ & $\begin{array}{l}\text { Copy of J. J. Callan } \\
\text { (1901) letter and map } \\
\text { in Wolf Research } \\
\text { Files. }\end{array}$ \\
\hline
\end{tabular}


Table A.1, continued

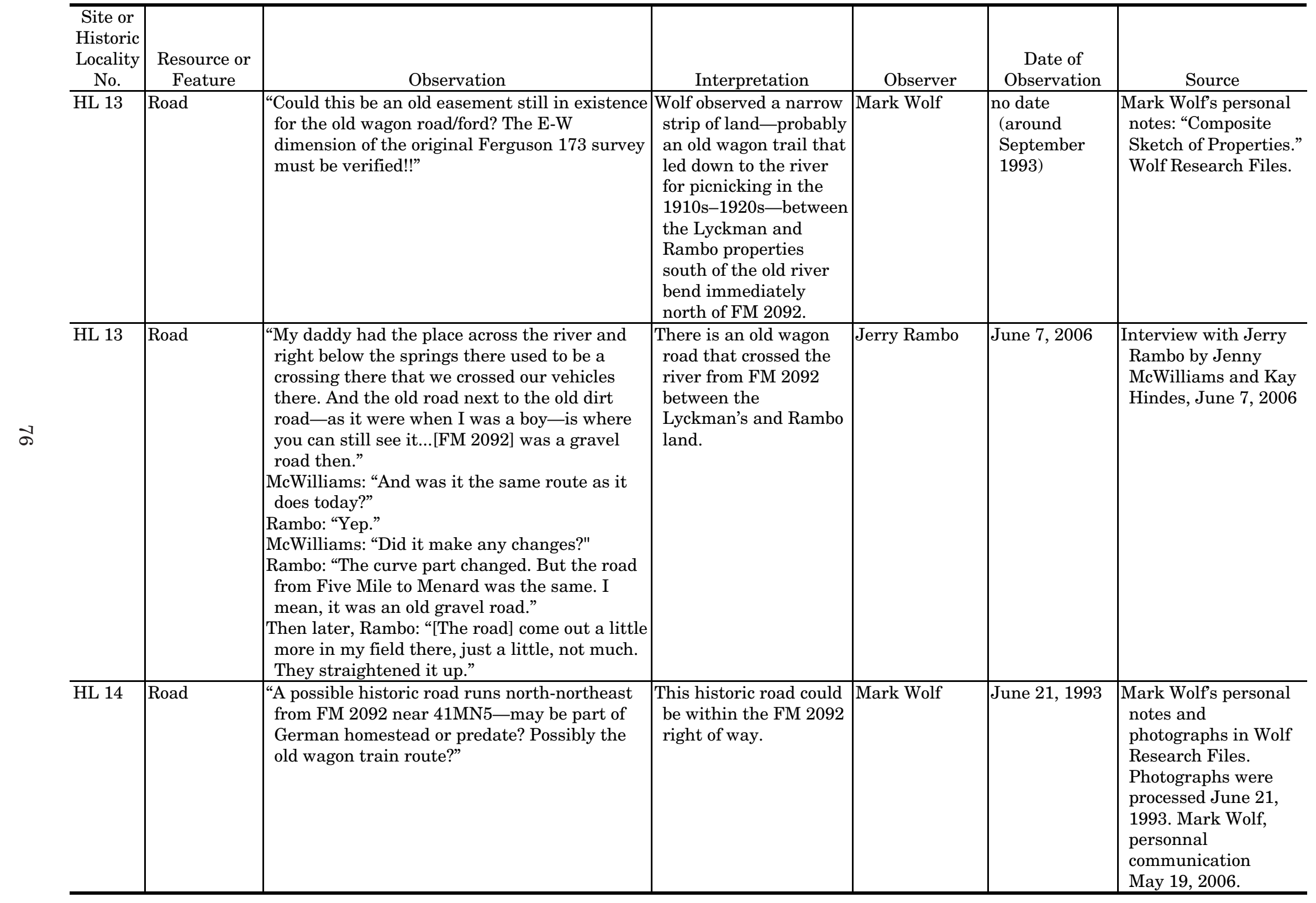


Table A.1, continued

\begin{tabular}{|c|c|c|c|c|c|c|}
\hline $\begin{array}{c}\text { Site or } \\
\text { Historic } \\
\text { Locality } \\
\text { No. }\end{array}$ & $\begin{array}{l}\text { Resource or } \\
\text { Feature }\end{array}$ & Observation & Interpretation & Observer & $\begin{array}{c}\text { Date of } \\
\text { Observation }\end{array}$ & Source \\
\hline HL 15 & Road & $\begin{array}{l}\text { McWilliams: "Do you know if this road today } \\
\text { [FM 2092] follows an old wagon road?" } \\
\text { Rambo: "Oh yeah, it was a wagon road at one } \\
\text { time or another because my great- } \\
\text { grandparents owned } 80 \text { sections of land up } \\
\text { here [to the north] and the wagon road that } \\
\text { they used back in there [later he adds that } \\
\text { this was in the 1910-1920s and in the } 1800 \text { s] } \\
\text { has got where the wagon wheel wore the stone } \\
\text { out and the print of the wagon wheels is still } \\
\text { there-in the stone. But there in Mr. Clark's } \\
\text { ranch over there. ...That road came from...here } \\
\text { [see map]...to the Brady Highway I'm guessing } \\
\text { about } 5 \text { miles across there and it's through Mr. } \\
\text { Clark's ranch there....and that was the road } \\
\text { that they used to go to Brady." } \\
\text { McWilliams: "And was that the same road as it } \\
\text { is today?" } \\
\text { Rambo: "No, huh-uh." } \\
\text { McWilliams: "It crossed right here by Fivemile } \\
\text { Crossing." } \\
\text { Hindes: "Did it tie into this highway?" Rambo } \\
\text { goes on to explain that the stagecoach stop } \\
\text { [referred to as Splittgerber's (Pierce } 1946: 165 \text { )] } \\
\text { was on the road to Mason and that's where the } \\
\text { old wagon road headed. }\end{array}$ & $\begin{array}{l}\text { FM } 2092 \text { followed a } \\
\text { wagon road before it } \\
\text { was gravel. The wagon } \\
\text { road tied in near } \\
\text { Fivemile Crossing and } \\
\text { went north to Brady. }\end{array}$ & Jerry Rambo & June 7, 2006 & $\begin{array}{l}\text { Interview with Jerry } \\
\text { Rambo by Jenny } \\
\text { McWilliams and Kay } \\
\text { Hindes, June 7, } 2006\end{array}$ \\
\hline HL 16 & $\begin{array}{l}\text { Observation } \\
\text { on historic } \\
\text { road }\end{array}$ & $\begin{array}{l}\text { "In the field, Doug and I noticed an old road } \\
\text { that ran along the north side of FM } 2092 \text { and } \\
\text { a small concrete bridge. Later, in reviewing } \\
\text { the } 1954 \text { TxDOT engineering schematic maps, } \\
\text { we noticed that the previous road curved here } \\
\text { and the new FM } 2092 \text { straightened out this } \\
\text { curve." }\end{array}$ & $\begin{array}{l}\text { There are historic road- } \\
\text { related features ca. } \\
20-40 \text { m off the } \\
\text { existing road }\end{array}$ & $\begin{array}{l}\text { Doug Boyd and } \\
\text { Jenny } \\
\text { McWilliams }\end{array}$ & July 2006 & $\begin{array}{l}1954 \text { engineering } \\
\text { schematic for FM } \\
2092 \text { (Texas Highway } \\
\text { Department 1954) }\end{array}$ \\
\hline HL 17 & $\begin{array}{l}\text { Texas } \\
\text { Rangers } \\
\text { camp }\end{array}$ & $\begin{array}{l}\text { "Mrs. [Priscilla] Ellis was born near Burnet in } \\
\text { 1869. Her father, Joe Glasscock, Sr., moved to } \\
\text { Menard County in 1875, settling at the old } \\
\text { rangers' camp about two miles below the } \\
\text { village [Menardville]." }\end{array}$ & $\begin{array}{l}\text { Texas Rangers camped } \\
2 \text { miles below Menard. }\end{array}$ & $\begin{array}{l}\text { Mrs. Priscilla } \\
\text { Ellis }\end{array}$ & April 1, 1946 & Pierce (1946:148) \\
\hline
\end{tabular}


Table A.1, continued

\begin{tabular}{|c|c|c|c|c|c|c|}
\hline $\begin{array}{l}\text { Site or } \\
\text { Historic } \\
\text { Locality } \\
\text { No. } \\
\end{array}$ & $\begin{array}{l}\text { Resource or } \\
\text { Feature }\end{array}$ & Observation & Interpretation & Observer & $\begin{array}{c}\text { Date of } \\
\text { Observation }\end{array}$ & Source \\
\hline$\overline{\mathrm{HL}} 17$ & $\begin{array}{l}\text { Texas } \\
\text { Rangers } \\
\text { camp }\end{array}$ & $\begin{array}{l}\text { "The [Texas Rangers'] camp was located in a } \\
\text { fine pecan grove on the [San Saba] river about } \\
\text { two miles below Menardville." She goes on to } \\
\text { describe the wildlife. }\end{array}$ & $\begin{array}{l}\text { Mrs. Dan Roberts } \\
\text { camped with her } \\
\text { husband (Captain) and } \\
\text { the Texas Rangers for } \\
\text { about two years- } \\
\text { beginning just after } \\
\text { their wedding in the } \\
\text { summer of } 1875 \text {. They } \\
\text { camped } 2 \text { miles below } \\
\text { (downriver) from } \\
\text { Menard. They left in } \\
\text { 1877, but returned } \\
\text { again in the spring of } \\
1878, \text { camping } 5 \text { miles } \\
\text { below Fort McKavett, } \\
20 \text { miles above their } \\
\text { former camp. How big } \\
\text { would this camp have } \\
\text { been? Could it extend } \\
\text { into the project area? }\end{array}$ & $\begin{array}{c}\text { Mrs. Dan } \\
\text { Roberts }\end{array}$ & $1875-1877$ & $\begin{array}{c}\text { Pierce (1946:91), } \\
\text { Roberts (1928:11) }\end{array}$ \\
\hline \multirow[t]{2}{*}{$\begin{array}{l}\text { HL } 17 \\
\end{array}$} & $\begin{array}{l}\text { Texas } \\
\text { Rangers } \\
\text { camp }\end{array}$ & $\begin{array}{l}\text { “...I took Mrs. Roberts up to Menardville, where } \\
\text { we were to take our Ranger quarters for the } \\
\text { winter...I prepared quarters for us, about one } \\
\text { and one-half miles from the town, and we soon } \\
\text { went into camp. Here we spent our honey- } \\
\text { moon, with sweet King Nature, watching the } \\
\text { wild ducks and geese splash in the beautiful } \\
\text { water of the San Saba River.” He goes on to } \\
\text { describe the wildlife. }\end{array}$ & $\begin{array}{l}\text { Capt. Dan Roberts } \\
\text { made a home for } \\
\text { himself and his wife } \\
1^{11 / 2} \text { miles from town, } \\
\text { presumably also } \\
\text { downstream near the } \\
\text { Rangers camp. If their } \\
\text { quarters were half a } \\
\text { mile from the camp, } \\
\text { could there be other } \\
\text { quarters outside the } \\
\text { camp? }\end{array}$ & $\begin{array}{l}\text { Capt. Dan } \\
\text { Roberts }\end{array}$ & $1875-1877$ & $\begin{array}{l}\text { Roberts and Roberts } \\
(1987: 84)\end{array}$ \\
\hline & $\begin{array}{l}\text { General oral } \\
\text { history }\end{array}$ & Rambo's version of the story of Humpy Jackson & $\begin{array}{l}\text { Another version of the } \\
\text { Humpy Jackson story }\end{array}$ & Jerry Rambo & June 7, 2006 & $\begin{array}{l}\text { Interview with Jerry } \\
\text { Rambo by Jenny } \\
\text { McWilliams and Kay } \\
\text { Hindes, June 7, 2006 } \\
\end{array}$ \\
\hline
\end{tabular}


Table A.1, continued

\begin{tabular}{|c|c|c|c|c|c|c|}
\hline $\begin{array}{c}\text { Site or } \\
\text { Historic } \\
\text { Locality } \\
\text { No. } \\
\end{array}$ & $\begin{array}{c}\text { Resource or } \\
\text { Feature }\end{array}$ & Observation & Interpretation & Observer & $\begin{array}{c}\text { Date of } \\
\text { Observation }\end{array}$ & Source \\
\hline & Graves & $\begin{array}{l}\text { Humpy Jackson would "conceal himself on one } \\
\text { of the many peeks overlooking the road.... And } \\
\text { before [the African American soldiers] got by } \\
\text { [another one was killed]. It is even asserted } \\
\text { that the road from Fort McKavett to } \\
\text { Menardville is dotted with the negro graves, } \\
\text { victims of his terrible vengeance, but, of } \\
\text { course, this boast on the part of his friends is } \\
\text { an exaggeration, and I doubt his ever having } \\
\text { killed more than one or two from ambush...." }\end{array}$ & $\begin{array}{l}\text { How much does a } \\
\text { researcher accept from } \\
\text { "lore"? If old stories tell } \\
\text { of graves along the } \\
\text { highway, could there } \\
\text { be any truth to this? }\end{array}$ & $\begin{array}{l}\text { John Warren } \\
\text { Hunter, } \\
\text { apparently } \\
\text { from a story } \\
\text { told by Peter } \\
\text { Robertson }\end{array}$ & $\begin{array}{l}\text { December } 1, \\
1923\end{array}$ & Hunter (1923:4) \\
\hline & Graves & $\begin{array}{l}\text { “Tullos B. Smith was returning late in the } \\
\text { evening to his home in Menard, from the } \\
\text { Wilkerson Ranch, about sixteen miles away, } \\
\text { was mounted on a large black pony, and was } \\
\text { leading about two other horses. As he passed a } \\
\text { cluster of bushes, a few miles from his } \\
\text { destination, Tullos B. Smith was ambushed } \\
\text { and killed. Late in the evening the stage going } \\
\text { from San Antonio to El Paso came along and } \\
\text { found him. Since he was not scalped, some } \\
\text { local citizens thought perhaps he may not } \\
\text { have been killed by Indians. Searching parties } \\
\text { soon found moccasin tracks, however, and } \\
\text { other Indian signs. Wm. Templeton, Lewis } \\
\text { Wilson and David Thorp brought Tullos B. } \\
\text { Smith's body to Menard in a spring wagon. } \\
\text { Note: Author interviewed: J. F. P. Kruse, who } \\
\text { intended to [ac]company Tullos B. Smith to } \\
\text { the Wilkerson Ranch but was unable to find } \\
\text { his pony; Mr. And Mrs. Ben Ellis and Mr. and } \\
\text { Mrs. J. D. Carisle, who were early settlers in } \\
\text { that section. Dr. Landers' notes: '(Bullet hole } \\
\text { with arrow stuck into it).'” }\end{array}$ & 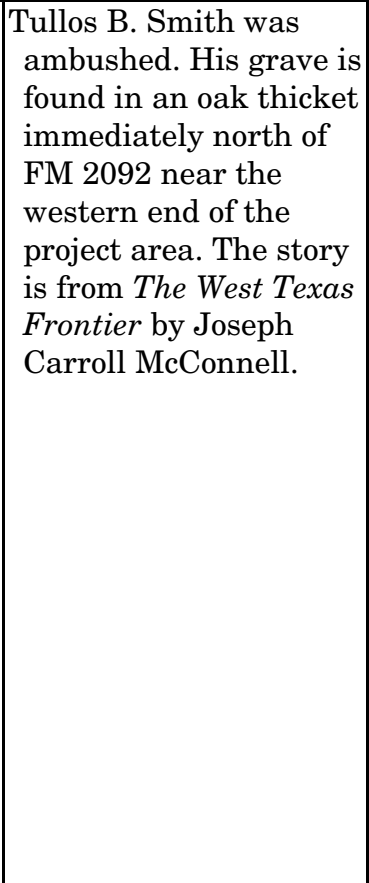 & $\begin{array}{l}\text { Joseph Carroll } \\
\text { McConnell }\end{array}$ & June 15, 1905 & McConnell (1933:696) \\
\hline
\end{tabular}


Table A.1, continued

\begin{tabular}{|c|c|c|c|c|c|c|}
\hline $\begin{array}{c}\text { Site or } \\
\text { Historic } \\
\text { Locality } \\
\text { No. }\end{array}$ & $\begin{array}{c}\text { Resource or } \\
\text { Feature }\end{array}$ & Observation & Interpretation & Observer & $\begin{array}{c}\text { Date of } \\
\text { Observation }\end{array}$ & Source \\
\hline & $\begin{array}{l}\text { Harris } \\
\text { Hollow }\end{array}$ & $\begin{array}{l}\text { McWilliams: "Have you ever seen water flowing } \\
\text { in this Harris Hollow?" } \\
\text { Rambo: "Oh, goodness, yes! Yeah, I can show } \\
\text { you in town where it flows through town. And } \\
\text { it comes through the city farm up here and } \\
\text { flows right on downstream." } \\
\text { McWilliams: "Is that just after a rain?" } \\
\text { Rambo: "Yup, after a rain." }\end{array}$ & $\begin{array}{l}\text { Water flows within } \\
\text { Harris Hollow after } \\
\text { rains. }\end{array}$ & Jerry Rambo & June 7, 2006 & $\begin{array}{l}\text { Interview with Jerry } \\
\text { Rambo by Jenny } \\
\text { McWilliams and Kay } \\
\text { Hindes, June 7, } 2006\end{array}$ \\
\hline & $\begin{array}{l}\text { Harris } \\
\text { Hollow }\end{array}$ & $\begin{array}{l}\text { "We then followed Harris Hollow all the way } \\
\text { back in through town and southwest of town. } \\
\text { Jerry [Rambo] said that there were more } \\
\text { springs up further-in the older days. We } \\
\text { drove up Menard St. from Bowie St. to } \\
\text { Houston St. and up through the foot of the } \\
\text { hills to the field where they have Song of } \\
\text { Silver play every year. Harris Hollow heads } \\
\text { back thorough the ranches for several miles } \\
\text { further southwest of Menard." }\end{array}$ & $\begin{array}{l}\text { Harris Hollow heads } \\
\text { several miles } \\
\text { southwest of Menard. }\end{array}$ & Jerry Rambo & June 7, 2006 & $\begin{array}{l}\text { Notes on interview } \\
\text { with Jerry Rambo by } \\
\text { Jenny McWilliams } \\
\text { and Kay Hindes, } \\
\text { June } 7,2006\end{array}$ \\
\hline & $\begin{array}{l}\text { Historic } \\
\text { artifacts }\end{array}$ & $\begin{array}{l}\text { "My daddy-back on his property back there, } \\
\text { well it's my property now-he found a calvary } \\
\text { button and then a calvary spur. On Scalp } \\
\text { Creek up there [from the Texas Rangers?] or it } \\
\text { could have been from the cavalry when they } \\
\text { were stationed at Fort McKavett because they } \\
\text { comb this area all the time-patrolling it. } \\
\text { There's no telling where they rode because } \\
\text { they rode horseback, see. But they probably } \\
\text { rode close to the road and then they probably } \\
\text { scouted and he could have been killed." }\end{array}$ & $\begin{array}{l}\text { Rambo didn't know any } \\
\text { stories about artifacts } \\
\text { found along the } \\
\text { countryside except for } \\
\text { the Native American } \\
\text { mano and matates } \\
\text { found on his land and } \\
\text { the calvary button and } \\
\text { spur found by his } \\
\text { father, also on his } \\
\text { land. }\end{array}$ & Jerry Rambo & June 7, 2006 & $\begin{array}{l}\text { Interview with Jerry } \\
\text { Rambo by Jenny } \\
\text { McWilliams and Kay } \\
\text { Hindes, June 7, } 2006\end{array}$ \\
\hline & $\begin{array}{l}\text { Historic } \\
\text { observation } \\
\text { of mission } \\
\text { location }\end{array}$ & $\begin{array}{l}\text { Hindes: "There's a bunch of lore associated with } \\
\text { that clump of oak [live] trees [north of the } \\
\text { location of the original historic marker]." } \\
\text { Rambo: "That's where they thought the mission } \\
\text { was." [see map] }\end{array}$ & $\begin{array}{l}\text { Again, Rambo thought } \\
\text { the mission was } \\
\text { located near where the } \\
\text { historical marker was } \\
\text { originally placed. }\end{array}$ & Jerry Rambo & June 7, 2006 & $\begin{array}{l}\text { Interview with Jerry } \\
\text { Rambo by Jenny } \\
\text { McWilliams and Kay } \\
\text { Hindes, June } 7,2006\end{array}$ \\
\hline
\end{tabular}


Table A.1, continued

\begin{tabular}{|c|c|c|c|c|c|c|}
\hline $\begin{array}{l}\text { Site or } \\
\text { Historic } \\
\text { Locality } \\
\text { No. }\end{array}$ & $\begin{array}{l}\text { Resource or } \\
\text { Feature }\end{array}$ & Observation & Interpretation & Observer & $\begin{array}{c}\text { Date of } \\
\text { Observation }\end{array}$ & Source \\
\hline & $\begin{array}{l}\text { Historic } \\
\text { observation } \\
\text { of possible } \\
\text { mission } \\
\text { burials }\end{array}$ & $\begin{array}{l}\text { "Hundreds of prospectors have been here from } \\
\text { time to time within the past fifty } \\
\text { years...[looking for] the lost mine and hidden } \\
\text { treasure. But none ever succeeded in finding } \\
\text { anything to indicate the presence of either, } \\
\text { excepting the remains of the smelter, some } \\
\text { crucibles, a few small slabs of lead containing } \\
\text { a considerable per centum of silver, some tools } \\
\text { and impliments [sic] and parts of human } \\
\text { bones." }\end{array}$ & $\begin{array}{l}\text { Human bones were } \\
\text { present in the early } \\
20 \text { th century }\end{array}$ & J. J. Callan & $\begin{array}{l}\text { January 4, } \\
1901\end{array}$ & $\begin{array}{l}\text { Copy of J. J. Callan } \\
\text { (1901) letter and map } \\
\text { in Wolf Research } \\
\text { Files. }\end{array}$ \\
\hline & Historic site & $\begin{array}{l}\text { "Otis told me the house currently occupied by } \\
\text { Monte Lyckman's family ws relocated to this } \\
\text { site after the large floods of the 30s. } \\
\text { Originally, it was sited north of the ravine } \\
\text { (Harris Hollow), on the opposite side of the } \\
\text { property's main road, near the southwestern } \\
\text { corner of the alfalfa field (some clay brick and } \\
\text { historic sherds were found in this location on } \\
\text { 9/4/93). When moved, the house was raised } \\
\text { significantly to place the floor out of the flood } \\
\text { water...." }\end{array}$ & $\begin{array}{l}\text { Historic site possibly } \\
\text { recorded by Carlson } \\
\text { may be previous } \\
\text { location of house; } \\
\text { check Carlson sites. }\end{array}$ & $\begin{array}{l}\text { Judge Lyckman } \\
\text { to Wolf }\end{array}$ & $\begin{array}{l}\text { September 10, } \\
1993\end{array}$ & $\begin{array}{l}\text { Mark Wolf's personal } \\
\text { notes: "Oral } \\
\text { Histories; 9/10/93 } \\
\text { Lyckman Property." } \\
\text { Wolf Research Files } \\
\text { and Hindes Research } \\
\text { Files. }\end{array}$ \\
\hline & $\begin{array}{l}\text { Mamine } \\
\text { Ditch Co. }\end{array}$ & $\begin{array}{l}\text { Mamine Ditch Company: Rambo talks about } \\
\text { irrigation system on the north side of the } \\
\text { river. And it will show up on his property } \\
\text { abstracts. Dams: Mamine Ditch dam marked } \\
\text { on map. McWilliams marked on map where } \\
\text { Rambo showed the Mamine Ditch. }\end{array}$ & $\begin{array}{l}\text { The Mamine Ditch } \\
\text { Company ran on the } \\
\text { north side of the river. } \\
\text { Rambo drew the dam } \\
\text { and ditch on our topo } \\
\text { map. }\end{array}$ & Jerry Rambo & June 7, 2006 & $\begin{array}{l}\text { Interview with Jerry } \\
\text { Rambo by Jenny } \\
\text { McWilliams and Kay } \\
\text { Hindes, June 7, } 2006\end{array}$ \\
\hline & $\begin{array}{l}\text { Note on Jerry } \\
\text { Rambo's } \\
\text { ancestors }\end{array}$ & $\begin{array}{l}\text { "Wilhelm was Jerry's great grandparents' name } \\
\text { and Futon [?] was his grandparents on his } \\
\text { mother's side. His grandfather emigrated from } \\
\text { Germany when he was } 19, \text { in the } 1860 \text { s." }\end{array}$ & $\begin{array}{l}\text { Rambo's ancestors are } \\
\text { the Wilhelms and } \\
\text { Futons, buried in the } \\
\text { pioneer cemetery. }\end{array}$ & Jerry Rambo & June 7, 2006 & $\begin{array}{l}\text { Interview with Jerry } \\
\text { Rambo by Jenny } \\
\text { McWilliams and Kay } \\
\text { Hindes, June 7, } 2006\end{array}$ \\
\hline
\end{tabular}


Table A.1, continued

\begin{tabular}{|c|c|c|c|c|c|c|}
\hline \begin{tabular}{c|} 
Site or \\
Historic \\
Locality \\
No. \\
\end{tabular} & $\begin{array}{c}\text { Resource or } \\
\text { Feature }\end{array}$ & Observation & Interpretation & Observer & $\begin{array}{c}\text { Date of } \\
\text { Observation }\end{array}$ & Source \\
\hline & Oak tree & $\begin{array}{l}\text { "Re: lore about an oak tree with cross carved in } \\
\text { it. Kay [Hindes] and Jerry [Rambo] went to } \\
\text { look for it, but never found it. They looked on } \\
\text { the north side of the river. There's a live oak } \\
\text { tree over there at Jerry's sister's home across } \\
\text { the river here, where his dad lived. It } \\
\text { measures } 26 \text { ' feet around the trunk. It was } \\
\text { that large when he was a boy. Later he adds: } \\
\text { 'The soil conservation come here and took } \\
\text { pictures of it and said that it was one of the } \\
\text { largest oak trees in Texas...right north of } \\
\text { where the marker is now.'” }\end{array}$ & $\begin{array}{l}\text { There is a large oak tree } \\
\text { on Rambo's land that } \\
\text { is } 26 \mathrm{ft} \text { in diameter. }\end{array}$ & Jerry Rambo & June 7, 2006 & $\begin{array}{l}\text { Notes on interview } \\
\text { with Jerry Rambo by } \\
\text { Jenny McWilliams } \\
\text { and Kay Hindes, } \\
\text { June } 7,2006\end{array}$ \\
\hline & $\begin{array}{l}\text { Mission } \\
\text { outbuilding }\end{array}$ & $\begin{array}{l}\text { "Derral [sic] Lewis' grandfather: Jim Lewis } \\
\text { arrived ca. 1880/ Reported that burned } \\
\text { timbers and foundation stones at the bend in } \\
\text { the river just east of 41MN23/ The timbers } \\
\text { were burned nearly to the ground and burned } \\
\text { charcoal [located at] [t] } \\
\text { river." }\end{array}$ & $\begin{array}{l}\text { Possibly outbuildings } \\
\text { east of the mission }\end{array}$ & Daryl Lewis & $\begin{array}{l}\text { January 12, } \\
1994\end{array}$ & $\begin{array}{l}\text { Kay Hindes' personal } \\
\text { notes; notebook dated } \\
\text { 1/12/94; Oral History } \\
\text { folder in Hindes } \\
\text { Research Files. }\end{array}$ \\
\hline & $\begin{array}{l}\text { Research } \\
\text { observations }\end{array}$ & $\begin{array}{l}\text { "Commissioner's court minutes should have } \\
\text { records of when the road was paved. Elsie } \\
\text { keeps the records at the courthouse. May have } \\
\text { maps in 'road minutes." }\end{array}$ & $\begin{array}{l}\text { Commissioner's court } \\
\text { records would have } \\
\text { information on the } \\
\text { history of FM } 2092 .\end{array}$ & Jerry Rambo & June 7, 2006 & $\begin{array}{l}\text { Interview with Jerry } \\
\text { Rambo by Jenny } \\
\text { McWilliams and Kay } \\
\text { Hindes, June 7, } 2006\end{array}$ \\
\hline & $\begin{array}{l}\text { Research } \\
\text { observations } \\
\text { on real } \\
\text { estate } \\
\text { abstracts }\end{array}$ & $\begin{array}{l}\text { Jerry Rambo has land abstracts that go back to } \\
\text { original land grant and describe the } \\
\text { purchasing and layout of his land along FM } \\
2092 \text {. Kay [Hindes] suggests that we look at } \\
\text { these abstracts as they might use the roads as } \\
\text { landmarks and might describe the springs } \\
\text { (also river course). }\end{array}$ & $\begin{array}{l}\text { Jerry Rambo's property } \\
\text { abstracts would have } \\
\text { useful information. }\end{array}$ & Jerry Rambo & June 7, 2006 & $\begin{array}{l}\text { Interview with Jerry } \\
\text { Rambo by Jenny } \\
\text { McWilliams and Kay } \\
\text { Hindes, June 7, } 2006\end{array}$ \\
\hline
\end{tabular}


Table A.1, continued

\begin{tabular}{|c|c|c|c|c|c|c|}
\hline $\begin{array}{c}\text { Site or } \\
\text { Historic } \\
\text { Locality } \\
\text { No. }\end{array}$ & $\begin{array}{c}\text { Resource or } \\
\text { Feature }\end{array}$ & Observation & Interpretation & Observer & $\begin{array}{c}\text { Date of } \\
\text { Observation }\end{array}$ & Source \\
\hline \multirow{4}{*}{$\begin{array}{c}\text { Locality } \\
\text { No. }\end{array}$} & River course & $\begin{array}{l}\text { "Visited with Jerry Rambo regarding flooding } \\
\text { conditions of field. Also confirmed change in } \\
\text { river course (at bend) which has occurred in } \\
\text { his lifetime." }\end{array}$ & \begin{tabular}{|} 
The river has changed \\
course in the past ca. \\
70 years [partly due to \\
the 1938 flood, I think]
\end{tabular} & Jerry Rambo & $\begin{array}{l}\text { September 4, } \\
1993\end{array}$ & $\begin{array}{l}\text { Mark Wolf's personal } \\
\text { notes; "September 4, } \\
\text { 1993, Menard, Texas } \\
\text { "Site Survey of } \\
\text { Smart/Ledbetter } \\
\text { Field." Hindes } \\
\text { Research Files. } \\
\end{array}$ \\
\hline & Road & $\begin{array}{l}\text { "Jack Watson-old road can be seen in his } \\
\text { property/1st rock house on the left between } \\
\text { road and river...according to Mr. Kothman" }\end{array}$ & $\begin{array}{l}\text { He doesn't know if the } \\
\text { road is east or west of } \\
\text { town. Is the Kothman } \\
\text { place east or west of } \\
\text { town? Entry below } \\
\text { suggests it's east. In } \\
\text { interview with Jerry } \\
\text { Rambo, he stated that } \\
\text { the Kothman place } \\
\text { was west of town and } \\
\text { not in the project area. }\end{array}$ & Jack Watson & June 1,1994 & $\begin{array}{l}\text { Kay Hindes' personal } \\
\text { notes: "Notes 6/1/94: } \\
\text { Jim Bowie Days } \\
\text { exhibit at Menard } \\
\text { Museum.” Oral } \\
\text { history folder in } \\
\text { Hindes Research } \\
\text { Files. }\end{array}$ \\
\hline & Road & $\begin{array}{l}\text { "Somewhere's in there in the 40s, I believe, or } \\
50 \text { s, whenever they wanted to pave this road, } \\
\text { well, they got the landowners and talked with } \\
\text { us and see if we would donate so much land on } \\
\text { each side for the right of way and the } \\
\text { landowner give the right of way. They didn't } \\
\text { even ask them to buy it because the } \\
\text { landowners wanted it pavement here instead } \\
\text { of the gravel road and the county had to keep } \\
\text { that up at the time." }\end{array}$ & $\begin{array}{l}\text { The landowners along } \\
\text { FM } 2092 \text { donated a } \\
\text { little bit of land for the } \\
\text { right of way so the } \\
\text { road could be paved. }\end{array}$ & Jerry Rambo & June 7, 2006 & $\begin{array}{l}\text { Interview with Jerry } \\
\text { Rambo by Jenny } \\
\text { McWilliams and Kay } \\
\text { Hindes, June 7, } 2006\end{array}$ \\
\hline & Road & $\begin{array}{l}\text { “Landowner donated 'not much' land. 'They } \\
\text { would donate the land if it didn't amount to } \\
\text { much...and so all of the landowners agreed to } \\
\text { this...' Jerry thought the road was paved in } \\
\text { the early '40s but really said he couldn't } \\
\text { remember when it was done.” }\end{array}$ & $\begin{array}{l}\text { Again, the landowners } \\
\text { along FM } 2092 \\
\text { donated land for the } \\
\text { right of way so that the } \\
\text { road could be paved. } \\
\text { This donated land } \\
\text { (right of way) may } \\
\text { have historic deposits. }\end{array}$ & Jerry Rambo & June 7, 2006 & $\begin{array}{l}\text { Notes on interview } \\
\text { with Jerry Rambo by } \\
\text { Jenny McWilliams } \\
\text { and Kay Hindes, } \\
\text { June 7, } 2006\end{array}$ \\
\hline
\end{tabular}


Table A.1, continued

\begin{tabular}{|c|c|c|c|c|c|c|}
\hline $\begin{array}{c}\text { Site or } \\
\text { Historic } \\
\text { Locality } \\
\text { No. }\end{array}$ & $\begin{array}{c}\text { Resource or } \\
\text { Feature }\end{array}$ & Observation & Interpretation & Observer & $\begin{array}{c}\text { Date of } \\
\text { Observation }\end{array}$ & Source \\
\hline & School & $\begin{array}{l}\text { There was a schoolhouse just east of Jerry's } \\
\text { road: "There is a fenceline that runs along } \\
\text { here down to the river and that schoolhouse } \\
\text { was right out in this field here." Jerry's father } \\
\text { went to school there "when he was a boy." Kay } \\
\text { [Hindes] later confirms with Jerry [Rambo] "It } \\
\text { was out beyond the right of way." }\end{array}$ & $\begin{array}{l}\text { There was a } \\
\text { schoolhouse just east } \\
\text { of Rambo Road, beyond } \\
\text { the right of way. } \\
\text { Surely there was a } \\
\text { road going to the } \\
\text { school. }\end{array}$ & Jerry Rambo & June 7, 2006 & $\begin{array}{l}\text { Interview with Jerry } \\
\text { Rambo by Jenny } \\
\text { McWilliams and Kay } \\
\text { Hindes, June 7, } 2006\end{array}$ \\
\hline & Spring & $\begin{array}{l}\text { "When I was a boy, my daddy and I used to } \\
\text { come down here to the springs down here [at } \\
\text { the far east end of Judge Lyckman's field]. It } \\
\text { flowed then somewhere about } 12-1,400 \\
\text { gallons a minute. It was a big spring. But then } \\
\text { in somewhere's about } 1925 \text { [It really sounds } \\
\text { like he says 1925, but he could have said } \\
\text { 1945-makes more sense] the river } \\
\text { rechanneled in here. And when it rechanneled } \\
\text { there, why then, it took this part of the river } \\
\text { where the spring was off. And then every time } \\
\text { the river flooded, why then it washed the mud } \\
\text { and silt in on the spring.... It filled it in with } \\
\text { mud and silt and it closed it. But the springs } \\
\text { seep out from there at the springs all the way } \\
\text { down to my camp house. They come out all } \\
\text { along the riverbanks. And so they're filtering } \\
\text { back into the river. But [at] the main spring } \\
\text { there, it really flowed a stream out there." }\end{array}$ & $\begin{array}{l}\text { The spring at the bend } \\
\text { in the river just east of } \\
\text { the mission site once } \\
\text { pumped } 1,200-1,400 \\
\text { gallons per minute. } \\
\text { According to Jerry, the } \\
\text { river changed course in } \\
\text { about } 1925 \text {. He } \\
\text { describes how the } \\
\text { change occurred. }\end{array}$ & Jerry Rambo & June 7, 2006 & $\begin{array}{l}\text { Interview with Jerry } \\
\text { Rambo by Jenny } \\
\text { McWilliams and Kay } \\
\text { Hindes, June 7, } 2006\end{array}$ \\
\hline & Springs & $\begin{array}{l}\text { Jerry Rambo learned to swim in the bend in the } \\
\text { river just below the spring. His grandmother } \\
\text { Rambo took him down there. Right above his } \\
\text { river crossing. }\end{array}$ & $\begin{array}{l}\text { The river crossing near } \\
\text { the wagon road was } \\
\text { actually a popular } \\
\text { place for families to } \\
\text { swim and picnic in the } \\
\text { 1920-1930s. We } \\
\text { should get more stories } \\
\text { about this history. }\end{array}$ & Jerry Rambo & June 7, 2006 & $\begin{array}{l}\text { Interview with Jerry } \\
\text { Rambo by Jenny } \\
\text { McWilliams and Kay } \\
\text { Hindes, June 7, } 2006\end{array}$ \\
\hline
\end{tabular}


Table A.1, continued

\begin{tabular}{|c|c|c|c|c|c|c|}
\hline $\begin{array}{l}\text { Site or } \\
\text { Historic } \\
\text { Locality } \\
\text { No. }\end{array}$ & $\begin{array}{c}\text { Resource or } \\
\text { Feature }\end{array}$ & Observation & Interpretation & Observer & $\begin{array}{c}\text { Date of } \\
\text { Observation }\end{array}$ & Source \\
\hline & Stage stop & $\begin{array}{l}\text { "Old stage stop located on the hill in Kothman } \\
\text { Commission Co. according to Jack Kothman- } \\
\text { located on the east in vicinity of old large oak } \\
\text { tree on the side of the hill." }\end{array}$ & $\begin{array}{l}\text { Possibly a stagecoach } \\
\text { stop east of town? }\end{array}$ & Jack Kothman & June 1, 1994 & $\begin{array}{l}\text { Kay Hindes' personal } \\
\text { notes; "Notes 6/1/94: } \\
\text { Jim Bowie Days } \\
\text { exhibit at Menard } \\
\text { Museum." Oral } \\
\text { History folder in } \\
\text { Hindes Research } \\
\text { Files. }\end{array}$ \\
\hline
\end{tabular}




\section{REFERENCES CITED}

Brown, Alicia

2006 Tullos Smith Burial Site, Menard County, Texas. TxGen Web Project. Available online at http://rootsweb.com/ txmenard/ cem/tulsmith/smitloc.htm [accessed May 23, 2006].

Callan, J. J.

1901 Correspondence to Adina de Zavala, 1901. Original in the Adina de Zavala papers, Box 2M133. The Center for American History, The University of Texas at Austin.

Carlson, Shawn Bonath

1991 The Search for San Sabá: An Apache Mission on the San Saba River, Menard County, Texas. Archeological Surveys No. 9. Archeological Research Laboratory, Texas A\&M University, College Station.

Hindes Research Files

n.d. Personal research files on Menard County history compiled by V. Kay Hindes, San Antonio, Texas.

Hunter, John Warren

1923 "Humpy" Jackson Wreaks Vengence." The Frontier Times 1(3):1-7.

McConnell, Joseph Carroll

1933 The West Texas Frontier: A Descriptive History of Early Times in Western Texas by Joseph Carroll McConnell, 1993 (Vol. 1) and 1939 (Vol. 2). Gazette Printing, Jacksboro, Texas. Available online from http://www.forttours.com/pages/ mcconnellbook.asp [accessed various dates 2006-2007].

Menard County Historical Society

1982 Menard County History: An Anthology. Anchor Publishing Co., San Angelo, Texas.
Menard News, Centennial Edition

Pierce, N. H.

1946 The Free State of Menard:A History of the County. Sixth Printing, 1989. Western Advertising Company, Menard, Texas.

Rambo, Jerry

2006 Interview with Jerry Rambo, June 7, 2006, at Monte Lyckman home near Menard, Texas, by V. Kay Hindes and Jennifer K. McWilliams.

Roberts, Mrs. D. W.

1928 A Woman's Reminiscences of Six Years in Camp with the Texas Rangers. Von Boeckmann-Jones Co., Austin, Texas.

Roberts, Capt. Dan W, and Mrs. D. W. Roberts

1987 Rangers and Sovereignty \& A Woman's Reminiscences of Six Years in Camp with the Texas Rangers. State House Press, Austin, Texas.

Texas Highway Department

1954 Plans of Proposed State Highway Improvement: State Project FM Highway No. 2092, September 1954. Plans recommended for approval October 13, 1954, by District Engineer J. A. Snell, final completed May 6, 1955.

Texas Historical Commission

2006 "Mission Santa Cruz de San Saba." 1936 Centennial subject marker No. 4835. Available online at http:// atlas.thc.state.tx.us/shell-county.htm [accessed April 10, 2006].

Wolf Research Files

n.d. Personal research files on Menard County history compiled by Mark R. Wolf, San Antonio, Texas. 


\section{APPENDIX B: Geological Profile Descriptions of}

Selected Backhoe Trenches

Karl W. Kibler 

The backhoe trenches reported here were excavated within Mechanical Search Areas 1-6 during the FM 2092 survey project from July 10 to 13, 2006. All trenches were located within the Texas Department of Transportation right of way along FM 2092. Locations of mechanical search areas are shown in Figure 3, and precise trench locations are shown in Figure 7.

Two radiocarbon assays were run by Beta Analytic, Inc., on organic sediment samples from backhoe trenches at Harris Hollow. The sample proveniences and assay results are as follows:

\section{Beta Sample No. 220548}

AMS assay on organic sediment from B2 horizon, $138-148 \mathrm{~cm}$ in Backhoe Trench 1. Sample is from $10 \mathrm{~cm}$ above a basal channel gravel deposit in the bottom of Harris Hollow, immediately north of FM 2092.

Conventional radiocarbon age is $2320 \pm 40$ B.P.

$13 \mathrm{C} / 12 \mathrm{C}$ Ratio is $-16.4 \mathrm{o} / \mathrm{oo}$

INTERCAL 98 Calibrated date is $410-360$ B.C.

Beta Sample No. 220549

AMS assay on organic sediment from $\mathrm{AB}$ horizon, 95-105 cm in Backhoe Trench 2. Sample is from a buried soil formed on a channel plug on rise just west of Harris Hollow and immediately north of FM 2092.

Conventional radiocarbon age is $1070 \pm 40$ B.P.

$13 \mathrm{C} / 12 \mathrm{C}$ Ratio is $-17.1 \mathrm{o} / \mathrm{oo}$

INTERCAL 98 Calibrated date is A.D. 890-1020

\section{BACKHOE TRENCH PROFILE DESCRIPTIONS}

\section{Backhoe Trench 1}

Location: Mechanical Search Area No. 2 at Harris Hollow. Bottom of Harris Hollow, north of FM 2092.

0-56 cm: $\quad$ Gravelly road fill material.

56-71 cm: Very dark grayish brown (10YR 3/2) clay loam, hard, moderate fine blocky angular structure, abrupt smooth lower boundary, AC horizon. 
71-102 cm: Very dark gray (10YR 3/1) clay, hard, moderate medium blocky angular structure, abrupt smooth lower boundary, AB horizon.

102-134 cm: Very dark gray (10YR 3/1) clay, hard, moderate medium prismatic structure breaks to moderate medium blocky angular structure, 2 percent gravels (dispersed, rounded, and granule- to pebble-sized), gravel stringer at $123 \mathrm{~cm}$, common clay films of ped faces, clear smooth lower boundary, B horizon.

134-158 cm: Very dark grayish brown (10YR 3/2) clay, hard, moderate medium blocky angular structure, 2 percent gravels (dispersed and rounded), common clay films on ped faces, faint redox mottling, abrupt smooth lower boundary, $\mathrm{B} 2$ horizon. ${ }^{14} \mathrm{C}$ age of $2320 \pm 40$ B.P. at $138-148 \mathrm{~cm}$.

158+cm: Channel gravel.

\section{Backhoe Trench 2}

Location: Mechanical Search Area No. 2 at Harris Hollow. West side of Harris Hollow, north of FM 2092.

0-44 cm: $\quad$ Gravelly road fill material.

44-77 cm: Very dark grayish brown (10YR 3/2) clay loam, hard, moderate fine granular structure, abrupt smooth lower boundary, AC horizon.

77-122 cm: Very dark gray (10YR 3/1) clay, hard, moderate medium blocky angular structure, 2 percent gravels (dispersed, rounded, granule- to pebble-sized), common clay films on ped faces, abrupt smooth lower boundary, $\mathrm{AB}$ horizon. ${ }^{14} \mathrm{C}$ age of $1070 \pm 40$ B.P. at $95-105 \mathrm{~cm}$.

122-153 cm: Dark grayish brown (10YR 4/2) clay, hard, moderate medium blocky angular structure, 1 percent gravels (dispersed, rounded, and granule- to pebble-sized), abrupt smooth lower boundary, Bw horizon.

153+ cm: Channel gravel.

\section{Backhoe Trench 3}

Location: Mechanical Search Area No. 2 at Harris Hollow. East side of Harris Hollow, north of FM 2092.

0-41 cm: $\quad$ Gravelly road fill material.

41-86 cm: $\quad$ Very dark grayish brown (10YR 3/2) clay loam, A horizon.

86-158+ cm: Dark gray to dark grayish brown clay loam (10yr 4/1 to 4/2) clay loam, moderate medium blocky angular structure, bw horizon. 


\section{Backhoe Trench 4}

Location: In Mechanical Search Area No. 4, south of FM 2092. West side of unnamed swale in 41MN53.

0-28 cm: $\quad$ Gravelly road fill material.

28-130+cm: Light brown (7.5YR 6/4) silty clay loam, weak prismatic structure breaks to moderate blocky angular structure, common soft carbonate masses $(2-5 \mathrm{~mm})$ and filaments, truncated B horizon on Pleistocene alluvium.

\section{Backhoe Trench 5}

Location: In Mechanical Search Area No. 4, south of FM 2092. Bottom of unnamed swale between 41MN53 and 41MN54.

0-58 cm: $\quad$ Gravelly road fill material.

58-105 cm: $\quad$ Very dark gray (10YR 3/1) clay loam, A horizon.

105-158 cm: Brown (7.5 YR 4/3) clay loam, B horizon.

158-215+ cm: Brown (7.5YR 5/4) silty clay loam, faint redox mottling, few to common spurious groundwater carbonates, B2 horizon.

\section{Backhoe Trench 6}

Location: In Mechanical Search Area No. 5, south of FM 2092. East side of unnamed swales in 41MN54.

0-24 cm: $\quad$ Gravelly road fill material.

24-93 cm: $\quad$ Dark grayish brown (10YR 4/2) clay loam, A horizon.

93-150+ cm: Brown (10YR 5/3) silty clay loam, weak prismatic structure breaks to moderate medium blocky angular structure, few dispersed gravels, Bw horizon.

\section{Backhoe Trench 7}

Location: In Mechanical Search Area No. 6, south of FM 2092 at Fivemile Crossing. In Holocene terrace $250 \mathrm{~m}$ west of San Saba River.

0-13 cm: $\quad$ Gravelly road fill material.

13-55 cm: Very dark grayish brown (10YR 3/2) silty clay loam, A horizon. 
55-162+ cm: Brown (10YR 4/3) silty clay loam, weak prismatic structure breaks to moderate medium blocky angular structure, Bw horizon.

\section{Backhoe Trench 8}

Location: In Mechanical Search Area No. 6, south of FM 2092 at Fivemile Crossing. In Holocene terrace $175 \mathrm{~m}$ west of San Saba River.

0-30 cm: $\quad$ Gravelly road fill material.

30-62 cm: $\quad$ Very dark grayish (10YR 3/2) silty clay loam, moderate medium blocky angular structure, A horizon.

62-136 cm: Brown (10YR 5/3) fine sandy clay loam, moderate medium blocky angular structure, Bw horizon.

136-160+ cm: Channel gravel.

\section{Backhoe Trench 9}

Location: In Mechanical Search Area No. 6, south of FM 2092 at Fivemile Crossing. In Holocene terrace 325 m west of San Saba River.

0-68+ cm: Channel gravel (upper fine-grained alluvium has been removed by road construction).

\section{Backhoe Trench 10}

Location: In Mechanical Search Area No. 6, south of FM 2092 at Fivemile Crossing. In Holocene terrace $375 \mathrm{~m}$ west of San Saba River.

0-44 cm: $\quad$ Very dark grayish (10YR 3/2) silty clay loam.

44-84 cm: Brown (10YR 4/3) silty clay loam, weak prismatic structure breaks to moderate medium blocky angular structure, Bw horizon.

84-87+cm: Channel gravel.

\section{Backhoe Trench 11}

Location: In Mechanical Search Area No. 6, south of FM 2092, at Fivemile Crossing. On higher Pleistocene terrace 225 m east of San Saba River, just east of 41MN55.

0-34 cm: Brown (7.5YR 4/2) silty clay loam, moderate medium blocky angular structure, A horizon. 
34-102 cm: Brown (7.5YR 5/4) silty clay loam, moderate medium prismatic structure breaks to moderate medium blocky angular structure, B horizon.

102-125+cm: Light brown (7.5YR 6/4) silt loam, weak medium prismatic structure breaks to moderate fine blocky angular structure, common soft nodules and masses (ca. $5 \mathrm{~mm}$ ) of carbonate that increase to 50 percent with depth, Bk horizon.

\section{Backhoe Trench 12}

Location: In Mechanical Search Area No. 3, south of FM 2092. South of the confluence of Harris Hollow and the San Saba River, about 175 m east of Mission San Sabá (41MN23).

0-16 cm: $\quad$ Gravelly road fill material.

16-52 cm: Dark grayish brown (10YR 4/2) clay loam, moderate medium blocky subangular structure, A horizon.

52-132 cm: Brown (7.5YR 4/3) clay loam, weak medium prismatic structure breaks to moderate medium blocky angular structure, $\mathrm{AB}$ horizon.

132-152+cm: Brown (7.5YR 5/3) clay loam, moderate medium blocky angular structure, Bw horizon.

\section{Backhoe Trench 13}

Location: In Mechanical Search Area No. 3, south of FM 2092. Southeast of the confluence of Harris Hollow and the San Saba River, about 250 m east of Mission San Sabá (41MN23).

0-29 cm: $\quad$ Gravelly road fill material.

29-58 cm: Very dark gray (10YR 3/1) clay loam, moderate medium blocky subangular structure, A horizon.

58-96 cm: Brown (7.5YR 4/3) clay loam, weak medium prismatic structure breaks to moderate medium blocky angular structure, $\mathrm{AB}$ horizon.

96-153+cm: Brown (7.5YR 5/3) clay loam, moderate medium blocky angular structure, Bw horizon. 

APPENDIX C: Summary of Excavation Results at Archeological Sites in the

FM 2092 Survey Area 



\begin{tabular}{|c|c|c|}
\hline \multicolumn{3}{|c|}{ Table C.1. Summary of excavation results at or near archeological sites. Only sites where mechanical excavations were conducted } \\
\hline \multicolumn{3}{|r|}{$41 \mathrm{MN} 15$} \\
\hline \multicolumn{2}{|l|}{ Description: } & Light prehistoric and historic surface scatter \\
\hline \multirow{2}{*}{\multicolumn{2}{|c|}{$\begin{array}{l}\text { Site Expanse in ROW: } \\
\text { Surface Survey Results and Site }\end{array}$}} & $425 \mathrm{~m}(\mathrm{E}-\mathrm{W})$ x $25 \mathrm{~m}(\mathrm{~N}-\mathrm{S})$ \\
\hline & & $\begin{array}{l}\text { Originally recorded by Carlson in 1991, this prehistoric/historic site appears to extend into the ROW, } \\
\text { although very lightly. A few pieces of debitage and } 1 \text { fire-cracked rock were observed on the surface of the } \\
\text { site at the far western end near Auger Test } 30 \text {. }\end{array}$ \\
\hline Backhoe Trenches & Depth & Results \\
\hline none & -- & -- \\
\hline Auger Tests & Depth & Results \\
\hline AT 30 & $80 \mathrm{~cm}$ & 1 possible tested cobble, 1 small corroded iron fragment \\
\hline AT 31 & $80 \mathrm{~cm}$ & 11 flake fragments (probably road fill), 2 thin metal fragments \\
\hline AT 32 & $114 \mathrm{~cm}$ & 1 small flake \\
\hline AT 33 & $79 \mathrm{~cm}$ & No recovery \\
\hline AT 34 & $82 \mathrm{~cm}$ & No recovery \\
\hline AT 35 & $38 \mathrm{~cm}$ & No recovery \\
\hline AT 36 & $50 \mathrm{~cm}$ & No recovery \\
\hline AT 37 & $28 \mathrm{~cm}$ & No recovery \\
\hline Shovel Tests & Depth & Results \\
\hline \multirow{3}{*}{\begin{tabular}{|l|} 
ST $15-1$ \\
ST $15-2$ \\
ST $15-3$ \\
\end{tabular}} & $50 \mathrm{~cm}$ & Level $2(20-40 \mathrm{~cm}): 1$ small bifacially flaked core \\
\hline & $40 \mathrm{~cm}$ & No recovery \\
\hline & $10 \mathrm{~cm}$ & No recovery \\
\hline \multicolumn{3}{|c|}{\begin{tabular}{|ll} 
& $41 \mathrm{MN} 20$ \\
\end{tabular}} \\
\hline \multirow{3}{*}{\multicolumn{2}{|c|}{$\begin{array}{l}\text { Description: } \\
\text { Site Expanse in ROW: } \\
\text { Surface Survey Results and Site } \\
\text { Description: }\end{array}$}} & Light prehistoric and historic scatter \\
\hline & & $100 \mathrm{~m}(\mathrm{E}-\mathrm{W}) \times 25 \mathrm{~m}(\mathrm{~N}-\mathrm{S})$ \\
\hline & & $\begin{array}{l}\text { A barn appears at this location on the } 1954 \text { Texas Highway Department engineering schematic for FM } \\
2092 \text {. A well house and three huge oak trees are } 6-20 \mathrm{~m} \text { north of the fence line. The site was originally } \\
\text { recorded by Carlson in } 1991 \text {. A light scatter of flakes and burned rock was observed along the fence line, } \\
\text { primarily near the eastern extent of the site boundaries. }\end{array}$ \\
\hline \multirow{2}{*}{$\begin{array}{c}\text { Backhoe Trenches } \\
\text { none }\end{array}$} & Depth & Results \\
\hline & -- & -- \\
\hline Auger Tests & Depth & Results \\
\hline AT 25 & $100 \mathrm{~cm}$ & 4 fire-cracked rocks, 1 possible tested cobble \\
\hline \multirow{2}{*}{$\begin{array}{r}\text { AT } 26 \\
\text { AT } 27 \\
\end{array}$} & $90 \mathrm{~cm}$ & 5 possible flakes \\
\hline & $52 \mathrm{~cm}$ & 10 possible flakes, 1 core \\
\hline \multirow{2}{*}{\begin{tabular}{|r|} 
Shovel Tests \\
ST $20-1$
\end{tabular}} & Depth & Results \\
\hline & $50 \mathrm{~cm}$ & $\begin{array}{l}\text { Level } 1(0-20 \mathrm{~cm}): 3 \text { brown bottle glass (modern); Level } 2(20-40 \mathrm{~cm}): 1 \text { piece of dark grayish black glass; } \\
\text { Level } 3(40-50 \mathrm{~cm}) \text { : no recovery }\end{array}$ \\
\hline ST 20-2 & $10 \mathrm{~cm}$ & Level $1(0-10 \mathrm{~cm}): 1$ possible flake \\
\hline ST $20-3$ & $40 \mathrm{~cm}$ & Level $1(0-20 \mathrm{~cm}): 4$ pieces of amber glass (lightly patinated); Level $2(20-40 \mathrm{~cm})$ : no recovery \\
\hline
\end{tabular}




\begin{tabular}{|c|c|c|}
\hline & & $41 \mathrm{MN23}$ \\
\hline Description: & & Mission Santa Cruz de San Saba and associated Native American artifact scatter \\
\hline Site Expanse in RO & & $225 \mathrm{~m}(\mathrm{E}-\mathrm{W}) \times 25 \mathrm{~m}(\mathrm{~N}-\mathrm{S})$ \\
\hline $\begin{array}{l}\text { Surface Survey Res } \\
\text { Description: }\end{array}$ & ts and Site & $\begin{array}{l}\text { No artifacts observed on surface, but ground visibility was not good. This site was originally recorded by } \\
\text { Hindes, Wolf, and Hall in 1993. Although the Spanish colonial site boundaries are still applicable, the } \\
\text { Native American component may extend west of the original site boundary. }\end{array}$ \\
\hline Backhoe Trenches & Depth & Results \\
\hline none & & N/A \\
\hline Gradall Trench & Depth & Results \\
\hline multiple & various & Cultural materials observed or recovered in several trenches \\
\hline Auger Tests & Depth & Results \\
\hline none & -- & -- \\
\hline Shovel Tests & Depth & Results \\
\hline ST 23-1 & $60 \mathrm{~cm}$ & $\begin{array}{l}\text { Level } 3(40-60 \mathrm{~cm}): 1 \text { possible flake, } 1 \text { fire-cracked rock, } 3 \text { mussel shell fragments. Deposits are disturbed } \\
\text { from } 0 \text { to } 30 \mathrm{~cm} .\end{array}$ \\
\hline ST 23-2 & $70 \mathrm{~cm}$ & Level $3(40-60 \mathrm{~cm}): 1$ mussel shell fragment, 1 charcoal fragment. Deposits are disturbed from 0 to $30 \mathrm{~cm}$. \\
\hline ST 23-3 & $60 \mathrm{~cm}$ & Level $3(40-60 \mathrm{~cm}): 1$ chert flake, 1 mussel shell fragment. Deposits are disturbed from 0 to $30 \mathrm{~cm}$. \\
\hline ST $23-5$ & $65 \mathrm{~cm}$ & Level $3(40-60 \mathrm{~cm}): 3$ mussel shell fragments. Deposits are disturbed from 0 to $30 \mathrm{~cm}$. \\
\hline ST 23-5 & $40 \mathrm{~cm}$ & $\begin{array}{l}\text { Level } 1(0-20 \mathrm{~cm}): 1 \text { milk glass fragment, } 3 \text { mussel shell fragments; Level } 2(20-40 \mathrm{~cm}): 1 \text { possile flake, } 1 \\
\text { chert chunk, } 5 \text { mussel shell fragments, } 1 \text { piece of window glass }\end{array}$ \\
\hline ST 23-6 & $50 \mathrm{~cm}$ & $\begin{array}{l}\text { Level } 1(0-20 \mathrm{~cm}): 2 \text { thinning flakes, } 1 \text { glass insulator fragment; Level } 2(20-40 \mathrm{~cm}): 1 \text { large utilized flake; } \\
\text { Level } 3(40-50 \mathrm{~cm}) \text { : charcoal }\end{array}$ \\
\hline & & 41MN53 \\
\hline Description: & & Prehistoric and light historic surface scatter \\
\hline Site Expanse in RO & & $80 \mathrm{~m}(\mathrm{E}-\mathrm{W}) \times 25 \mathrm{~m}(\mathrm{~N}-\mathrm{S})$ \\
\hline $\begin{array}{l}\text { Surface Survey Res } \\
\text { Description: }\end{array}$ & ts and Site & $\begin{array}{l}\text { Few scattered burned rocks, widely scattered flakes (primarily tertiary and bifacial thinning flakes), mussel } \\
\text { shells (including a few umbos), chert core, } 1 \text { chert unifacial tool fragment, and } 1 \text { middle-stage biface } \\
\text { fragment. A few scattered early-20th-century artifacts, including whiteware sherds and bottle glass } \\
\text { fragments, clear window glass fragments, and a steel file handle. Both prehistoric and historic artifacts } \\
\text { were primarily observed in the ROW on the south side of FM 2092. All artifacts are in a disturbed surface }\end{array}$ \\
\hline Backhoe Trenches & Depth & Results \\
\hline BHT 4 & $130 \mathrm{~cm}$ & No artifacts observed \\
\hline Auger Tests & Depth & Results \\
\hline AT 47 & $72 \mathrm{~cm}$ & 4 probable flakes \\
\hline Shovel Tests & Depth & Results \\
\hline none & -- & -- \\
\hline
\end{tabular}




\begin{tabular}{|c|c|c|}
\hline & & $41 \mathrm{MN54}$ \\
\hline Description: & & Prehistoric surface scatter with a light scatter of historic (modern) glass \\
\hline Site Expanse in RO & & $30-40 \mathrm{~m}(\mathrm{E}-\mathrm{W}) \times 25 \mathrm{~m}(\mathrm{~N}-\mathrm{S})$ \\
\hline $\begin{array}{l}\text { Surface Survey Res } \\
\text { Description: }\end{array}$ & ts and Site & $\begin{array}{l}\text { Few scattered burned rocks, widely scattered flakes including } 2 \text { secondary utilized flakes and tertiary } \\
\text { flakes (large and small, some patinated), } 1 \text { chert uniface fragment, a chert core, and mussel shell umbos } \\
\text { and fragments. Brown bottle glass was also observed. Artifacts were more common in the ROW on the } \\
\text { south side of FM 2092, but were present to the north ROW as well. Material was concentrated in eroded } \\
\text { areas in disturbed contexts. Some material may have been brought up to the surface when buried utility } \\
\text { lines were dug. All artifacts are in a surface context, possibly reaching a depth of } 20 \mathrm{~cm} \text {. No diagnostics } \\
\text { were found, but the age of the deposit suggests these materials are late, probably within the last } 2,000 \\
\text { years. }\end{array}$ \\
\hline Backhoe Trenches & Depth & Results \\
\hline BHT 6 & $150 \mathrm{~cm}$ & No artifacts observed \\
\hline Auger Tests & Depth & Results \\
\hline none & -- & -- \\
\hline Shovel Tests & Depth & Results \\
\hline none & -- & -- \\
\hline & & $41 \mathrm{MN55}$ \\
\hline Description: & & Surface scatter and shallowly buried Toyah phase occupation \\
\hline Site Expanse in RO & & $190 \mathrm{~m}(\mathrm{E}-\mathrm{W})$ x $25 \mathrm{~m}(\mathrm{~N}-\mathrm{S})$ \\
\hline $\begin{array}{l}\text { Surface Survey Res } \\
\text { Description: }\end{array}$ & ts and Site & $\begin{array}{l}\text { Scattered burned rocks, chert flakes (primary, tertiary, and bifacial thinning flakes), } 2 \text { utilized flake tools, } 2 \\
\text { blade flakes, } 1 \text { possible limestone mano, } 3 \text { pottery sherds (bone-tempered), and mussel shell umbos and } \\
\text { fragments. Artifacts were primarily observed in the ROW on the north side of FM 2092, but were also } \\
\text { present on the south. All artifacts were observed where the road cuts down into the margin of the } \\
\text { Pleistocene terrace. Materials appear to be eroding down the exposed road cut face, but fewer materials } \\
\text { were observed east of the terrace margin laying on the intact terrace surface on both the north and south } \\
\text { sides of FM 2092. }\end{array}$ \\
\hline Backhoe Trenches & Depth & Results \\
\hline BHT 11 & $125 \mathrm{~cm}$ & $\begin{array}{l}\text { No artifacts observed in trench. The age of the landform precludes the presence of any intact buried } \\
\text { cultural deposits. }\end{array}$ \\
\hline Auger Tests & Depth & Results \\
\hline none & -- & -- \\
\hline Shovel Tests & Depth & Results \\
\hline none & -- & -- \\
\hline
\end{tabular}


41MN56

\begin{tabular}{|c|c|c|}
\hline Description: & & Prehistoric surface scatter with limited deposition \\
\hline \multirow{2}{*}{\multicolumn{2}{|c|}{$\begin{array}{l}\text { Site Expanse in ROW: } \\
\text { Surface Survey Results and Site } \\
\text { Description: }\end{array}$}} & $160 \mathrm{~m}(\mathrm{E}-\mathrm{W}) \times 2 \mathrm{~m}(\mathrm{~N}-\mathrm{S})$ \\
\hline & & $\begin{array}{l}\text { Few scattered burned rocks, widely scattered flakes, and mussel shell. A biface was found near the } \\
\text { northern ROW fence line at Auger Test } 3 \text {. Artifacts were primarily observed in the ROW on the south side } \\
\text { of FM } 2092 \text { and were primarily in a disturbed surface context. A ca. } 40-\mathrm{cm} \text {-deep road cut runs along the } \\
\text { northern side of FM } 2092 \text { at this location. }\end{array}$ \\
\hline \multirow{2}{*}{$\begin{array}{c}\text { Backhoe Trenches } \\
\text { none }\end{array}$} & Depth & Results \\
\hline & -- & -- \\
\hline Auger Tests & Depth & Results \\
\hline AT 1 & $100 \mathrm{~cm}$ & 2 flakes \\
\hline AT 2 & $80 \mathrm{~cm}$ & 1 flake \\
\hline AT 3 & $72 \mathrm{~cm}$ & 1 flake \\
\hline \multirow{2}{*}{\begin{tabular}{|r|} 
AT 4 \\
Shovel Tests
\end{tabular}} & $90 \mathrm{~cm}$ & 1 flake \\
\hline & Depth & Results \\
\hline ST $56-1$ & $60 \mathrm{~cm}$ & No recovery \\
\hline ST $56-2$ & $50 \mathrm{~cm}$ & No recovery \\
\hline \begin{tabular}{|l|} 
ST 56-3 \\
ST $56-4$
\end{tabular} & $50 \mathrm{~cm}$ & No recovery \\
\hline \multirow{2}{*}{\begin{tabular}{|l|} 
ST $56-4$ \\
ST $56-5$
\end{tabular}} & $50 \mathrm{~cm}$ & No recovery \\
\hline & $50 \mathrm{~cm}$ & No recovery \\
\hline \begin{tabular}{|l|l} 
ST $56-5$ \\
ST $56-6$
\end{tabular} & $50 \mathrm{~cm}$ & $\begin{array}{l}\text { Level } 2(20-40 \mathrm{~cm}): 3 \text { flakes (1 primary, } 1 \text { secondary, and } 1 \text { possible), } 3 \text { mussel shell fragments; Level } 3 \text { (40- } \\
60 \mathrm{~cm}): 1 \text { mussel shell fragment }\end{array}$ \\
\hline \multicolumn{3}{|c|}{$\begin{array}{lr}41 \mathrm{MN57} & 410 \\
\end{array}$} \\
\hline \multicolumn{2}{|l|}{ Description: } & Ephemeral historic scatter \\
\hline \multicolumn{2}{|c|}{$\begin{array}{l}\text { Site Expanse in ROW: } \\
\text { Surface Survev Results and Site }\end{array}$} & $140 \mathrm{~m}(\mathrm{E}-\mathrm{W}) \times 5 \mathrm{~m}(\mathrm{~N}-\mathrm{S})$ \\
\hline \multicolumn{2}{|c|}{$\begin{array}{l}\text { Surface Survey Results and Site } \\
\text { Description: }\end{array}$} & $\begin{array}{l}2 \text { widely scattered areas of flakes and } 1 \text { core. Auger tests were positive, necessitating shovel tests, which } \\
\text { indicated only a light surface scatter of prehistoric artifacts, } 1 \text { whiteware sherd, a bone fragment (which } \\
\text { could be modern, historic, or prehistoric), and modern material. Artifacts were observed in the ROW on the } \\
\text { north side of FM } 2092 \text {. All artifacts were in a disturbed surface context. }\end{array}$ \\
\hline \multirow{2}{*}{\begin{tabular}{|c|} 
Backhoe Trenches \\
none
\end{tabular}} & Depth & Results \\
\hline & -- & -- \\
\hline Auger Tests & Depth & Results \\
\hline \multirow{2}{*}{\begin{tabular}{|r|} 
AT 13 \\
AT 14 \\
\end{tabular}} & $105 \mathrm{~cm}$ & 3 flakes, 1 mussel shell umbo, 2 mussel shell fragments, 1 whiteware sherd \\
\hline & $105 \mathrm{~cm}$ & 2 flakes \\
\hline Shovel Tests & Depth & Results \\
\hline $\begin{array}{r}\text { ST 57-1 } \\
\end{array}$ & $33 \mathrm{~cm}$ & No recovery \\
\hline \multirow{2}{*}{\begin{tabular}{|c|} 
ST 57-2 \\
ST 57-3 \\
ST 57-4
\end{tabular}} & $20 \mathrm{~cm}$ & Level $1(0-20 \mathrm{~cm}): 1$ core (unifacially flaked), 1 piece of weathered bone, 3 pieces modern bottle glass \\
\hline & $12 \mathrm{~cm}$ & No recovery (modern glass) \\
\hline ST 57-4 & $20 \mathrm{~cm}$ & No recovery (asphalt nodules) \\
\hline
\end{tabular}




\begin{tabular}{|c|c|c|}
\hline \multicolumn{3}{|r|}{$41 \mathrm{MN58}$} \\
\hline \multicolumn{2}{|l|}{ Description: } & Prehistoric surface scatter \\
\hline \multicolumn{2}{|c|}{ Site Expanse in ROW: } & $170 \mathrm{~m}(\mathrm{E}-\mathrm{W}) \times 5 \mathrm{~m}(\mathrm{~N}-\mathrm{S})$ \\
\hline \multicolumn{2}{|c|}{$\begin{array}{l}\text { Surface Survey Results and Site } \\
\text { Description: }\end{array}$} & $\begin{array}{l}\text { Several scattered burned rocks. Artifacts were only observed in the ROW on the north side of FM } 2092 \text { in a } \\
\text { disturbed surface context. }\end{array}$ \\
\hline Backhoe Trenches & Depth & Results \\
\hline none & -- & -- \\
\hline Auger Tests & Depth & Results \\
\hline AT 9 & $103 \mathrm{~cm}$ & 2 large flakes, 1 fire-cracked rock, $4+$ mussel shell fragments \\
\hline Shovel Tests & Depth & Results \\
\hline ST 58-1 & $20 \mathrm{~cm}$ & Level $1(0-20 \mathrm{~cm}): 1$ flake \\
\hline ST 58-2 & $10 \mathrm{~cm}$ & Level $1(0-10 \mathrm{~cm}): 1$ fire-cracked chert \\
\hline ST 58-3 & $10 \mathrm{~cm}$ & Level $1(0-10 \mathrm{~cm}): 1$ fire-cracked rock, 1 fire-cracked chert \\
\hline ST 58-4 & $40 \mathrm{~cm}$ & Level $1(0-20 \mathrm{~cm}): 1$ flake; Level $2(20-40 \mathrm{~cm}): 1$ piece of thin black glass \\
\hline \multicolumn{3}{|r|}{$41 \mathrm{MN59}$} \\
\hline \multicolumn{2}{|l|}{ Description: } & Prehistoric surface scatter \\
\hline \multicolumn{2}{|c|}{ Site Expanse in ROW: } & $170 \mathrm{~m}(\mathrm{E}-\mathrm{W}) \times 5 \mathrm{~m}(\mathrm{~N}-\mathrm{S})$ \\
\hline \multicolumn{2}{|c|}{$\begin{array}{l}\text { Surface Survey Results and Site } \\
\text { Description: }\end{array}$} & $\begin{array}{l}\text { Few scattered burned rocks, very widely scattered flakes and mussel shells. Three flakes and one fire- } \\
\text { cracked rock found in the ROW near Auger Test } 49.3 \text { additional flakes, } 1 \text { core, and } 4 \text { fire-cracked rocks } \\
\text { found scattered between Auger Test } 49 \text { and Auger Test } 50 \text { and to the east. Artifacts were only observed in } \\
\text { the ROW on the north side of FM } 2092 \text {. All artifacts are in a surface context, which is disturbed within the } \\
\text { ROW, and in a plowed field to the north. }\end{array}$ \\
\hline Backhoe Trenches & Depth & Results \\
\hline none & -- & -- \\
\hline Auger Tests & Depth & Results \\
\hline AT 49 & $84 \mathrm{~cm}$ & 8 mussel shell umbo and mussel shell fragments \\
\hline AT 50 & $79 \mathrm{~cm}$ & 3 flakes, 2 mussel shell umbos and mussel shell fragments \\
\hline Shovel Tests & Depth & Results \\
\hline none & -- & -- \\
\hline
\end{tabular}




\begin{tabular}{|c|c|c|}
\hline & & $41 \mathrm{MN60}$ \\
\hline Description: & & Historic homesite with light prehistoric scatter \\
\hline Site Expanse in RO & & $120 \mathrm{~m}(\mathrm{E}-\mathrm{W}) \times 2 \mathrm{~m}(\mathrm{~N}-\mathrm{S})$ \\
\hline $\begin{array}{l}\text { Surface Survey Res } \\
\text { Description: }\end{array}$ & ts and Site & $\begin{array}{l}\text { Numerous bricks, cinderblocks, and metal scraps on the surface immediately south of the ROW. A few } \\
\text { historic artifacts were observed on the surface in the right of way. A wooden windmill stand was erected } \\
\text { over an old brick well ca. } 20 \text { m north of the fence line. A house appears in this location and close to the old } \\
\text { road on the } 1954 \text { Texas Highway Department engineering schematic for FM } 2092 \text {. }\end{array}$ \\
\hline Backhoe Trenches & Depth & Results \\
\hline none & -- & -- \\
\hline Auger Tests & Depth & Results \\
\hline AT 18 & $80 \mathrm{~cm}$ & $\begin{array}{l}6 \text { possible flakes, charcoal, } 8 \text { pieces of corroded iron, } 1 \text { lightly patinated clear glass fragment, } 1 \text { aqua mold- } \\
\text { formed glass fragment, } 1 \text { small animal long bone with spiral fracture }\end{array}$ \\
\hline AT 19 & $80 \mathrm{~cm}$ & 6 possible flakes, metal wire fencing staple (probably modern) \\
\hline AT 20 & $95 \mathrm{~cm}$ & several fragments of corroded iron (probably 20th century) \\
\hline Shovel Tests & Depth & Results \\
\hline ST 60-1 & $80 \mathrm{~cm}$ & $\begin{array}{l}\text { Level } 1(0-20 \mathrm{~cm}): 1 \text { milk glass bottle rim, } 1 \text { washer, } 3 \text { corroded metal scraps, } 1 \text { tin can piece, } 1 \text { cut long bone } \\
\text { fragment, } 1 \text { wire, } 1 \text { clear glass }\end{array}$ \\
\hline & & Level $2(20-40 \mathrm{~cm}): 1$ flake, 8 corroded metal scraps, 2 pieces of wire, 2 clear glass, 1 small animal vertebra \\
\hline & & Level $3(40-60 \mathrm{~cm}): 8$ corroded metal scraps, 2 bone fragments, 1 piece of wire \\
\hline & & Level $4(60-80 \mathrm{~cm}): 3$ pieces of wire, 2 corroded metal scraps \\
\hline ST 60-2 & $50 \mathrm{~cm}$ & Level $1(0-20 \mathrm{~cm}): 20+$ pieces of clear thin bottle glass, 1 aqua glass, 2 sherds decorative transferware \\
\hline & & $\begin{array}{l}\text { Level } 2(20-40 \mathrm{~cm}): 1 \text { transferware printed whiteware sherd (same as above), } 1 \text { cut nail, } 3 \text { metal can rim } \\
\text { fragments, } 1 \text { clear glass (patinated), } 1 \text { burned cut bone fragment, charcoal }\end{array}$ \\
\hline & & Level $3(40-50 \mathrm{~cm})$ : no recovery \\
\hline & & Level $4(60-80 \mathrm{~cm})$ : no recovery \\
\hline ST $60-3$ & $50 \mathrm{~cm}$ & $\begin{array}{l}\text { Level } 1(0-20 \mathrm{~cm}): .22 \text {-caliber shell, } 1 \text { corroded scrap metal, } 1 \text { undecorated whiteware, patinated glass (1 } \\
\text { patinated glass bottle, } 2 \text { oxidized, } 1 \text { aqua, } 2 \text { clear), } 1 \text { metal bottle cap, aluminum foil } \\
\text { Level } 2(20-40 \mathrm{~cm}): 1 \text { fence staple, } 3 \text { corroded metal scraps, } 1 \text { large whiteware sherd, } 1 \text { gold-painted } \\
\text { whiteware sherd }\end{array}$ \\
\hline & & Level $3(40-50 \mathrm{~cm})$ : no recovery \\
\hline
\end{tabular}




\begin{tabular}{|c|c|c|}
\hline & & $41 \mathrm{MN} 61$ \\
\hline Description: & & Prehistoric surface scatter \\
\hline Site Expanse in ROV & & $110 \mathrm{~m}(\mathrm{E}-\mathrm{W})$ x $5 \mathrm{~m}(\mathrm{~N}-\mathrm{S})$ \\
\hline $\begin{array}{l}\text { Surface Survey Rest } \\
\text { Description: }\end{array}$ & ts and Site & $\begin{array}{l}\text { No cultural materials on surface. This is the location of the Buierer home, a large wooden structure that } \\
\text { appears to date to the late } 19 \text { th century, and a smaller stone cottage immediately to the west, which may } \\
\text { date to the } 1920 \mathrm{~s} \text { or } 1930 \mathrm{~s} \text {. }\end{array}$ \\
\hline Backhoe Trenches & Depth & Results \\
\hline none & -- & -- \\
\hline Auger Tests & Depth & Results \\
\hline AT 21 & $76 \mathrm{~cm}$ & 2 flakes \\
\hline AT 22 & $98 \mathrm{~cm}$ & old metal can, 1 small fragment of rusted iron \\
\hline AT 23 & $70 \mathrm{~cm}$ & 2 flakes \\
\hline Shovel Tests & Depth & Results \\
\hline ST $61-1$ & $40 \mathrm{~cm}$ & No recovery \\
\hline ST 61-2 & $10 \mathrm{~cm}$ & No recovery \\
\hline ST $61-3$ & $40 \mathrm{~cm}$ & Level $1(0-10 \mathrm{~cm}): 1$ flake \\
\hline $\begin{array}{l}\text { Notes: Backhoe trench } \\
\text { each site. No artifacts } \\
\text { detail in another repor }\end{array}$ & $\begin{array}{l}\text { and auger t } \\
\text { ere collected }\end{array}$ & $\begin{array}{l}\text { are numbered consecutively throughout the project area. Shovel tests are numbered consecutively within } \\
\text { m excavations except at 41MN23, Mission San Saba. Investigations at Mission San Saba are described in }\end{array}$ \\
\hline
\end{tabular}


